University of South Florida

DIGITAL COMMONS

@ UNIVERSITY OF SOUTH FLORIDA
Digital Commons @ University of

South Florida

7-1-2013

\title{
A Tool for Assessing the Economic Impact of Spending on Public Transit
}

CUTR

Follow this and additional works at: https://digitalcommons.usf.edu/cutr_nctr

\section{Recommended Citation}

"A Tool for Assessing the Economic Impact of Spending on Public Transit," National Center for Transit Research (NCTR) Report No. CUTR-NCTR-RR-2012-08, Center for Urban Transportation Research, University of South Florida, 2013.

DOI: https://doi.org/10.5038/CUTR-NCTR-RR-2012-08

Available at: https://scholarcommons.usf.edu/cutr_nctr/101

This Technical Report is brought to you for free and open access by the National Center for Transit Research (NCTR) Archive (2000-2020) at Digital Commons @ University of South Florida. It has been accepted for inclusion in Research Reports by an authorized administrator of Digital Commons @ University of South Florida. For more information, please contact digitalcommons@usf.edu. 


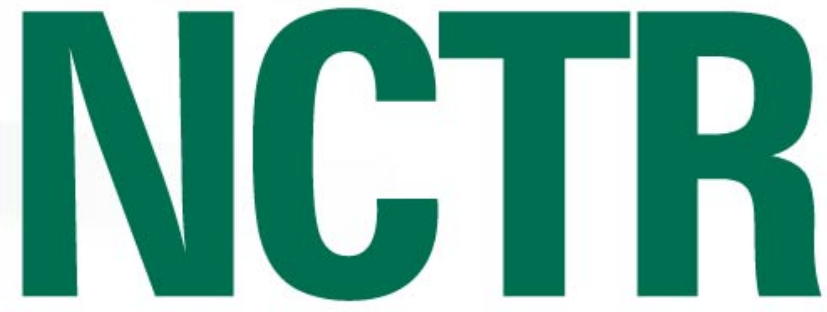

NATIONAL CENTER for TRANSIT RESEARCH

\title{
A Tool for Assessing the Economic Impacts of Spending on Public Transit
}

\author{
July 2013
}

PROJECT NO. FDOT BDK85 Task Work Order \#977-36

PREPARED FOR Florida Department of Transportation

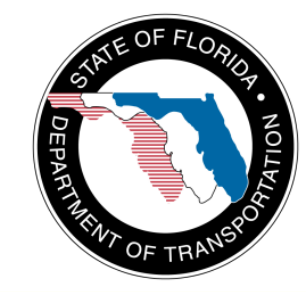




\section{A Tool for Assessing the Economic Impacts of Spending on Public Transit}

FDOT BDK85 Task Work Order 977-36

Prepared for:

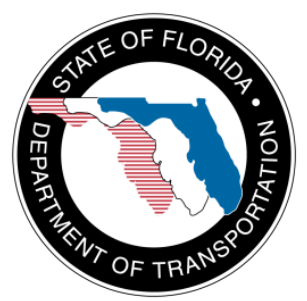

Florida Department of Transportation John Zielinski, Project Manager

Prepared by:

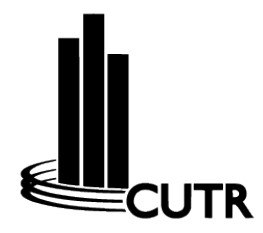

USF Center for Urban Transportation Research

Xuehao Chu, Ph.D., Senior Research Associate

Final Report

July 2013 


\section{Disclaimer}

The opinions, findings, and conclusions expressed in this publication are those of the authors and not necessarily those of the State of Florida Department of Transportation. 
Metric Conversion

\begin{tabular}{|c|c|c|c|c|}
\hline SYMBOL & WHEN YOU KNOW & MULTIPLY BY & TO FIND & SYMBOL \\
\hline \multicolumn{5}{|l|}{ LENGTH } \\
\hline in & inches & 25.4 & millimeters & $\mathrm{mm}$ \\
\hline ft & feet & 0.305 & meters & $\mathrm{m}$ \\
\hline yd & yards & 0.914 & meters & $\mathrm{m}$ \\
\hline mi & miles & 1.61 & kilometers & $\mathrm{km}$ \\
\hline \multicolumn{5}{|l|}{ VOLUME } \\
\hline fl oz & fluid ounces & 29.57 & milliliters & $\mathrm{mL}$ \\
\hline gal & gallons & 3.785 & liters & L \\
\hline $\mathrm{ft}^{3}$ & cubic feet & 0.028 & cubic meters & $\mathrm{m}^{3}$ \\
\hline$y \mathbf{d}^{3}$ & cubic yards & 0.765 & cubic meters & $\mathrm{m}^{3}$ \\
\hline \multicolumn{5}{|c|}{ NOTE: volumes greater than $1000 \mathrm{~L}$ shall be shown in $\mathrm{m}^{3}$} \\
\hline \multicolumn{5}{|l|}{ MASS } \\
\hline $\mathbf{O z}$ & ounces & 28.35 & grams & $\mathrm{g}$ \\
\hline lb & pounds & 0.454 & kilograms & $\mathrm{kg}$ \\
\hline $\mathbf{T}$ & short tons $(2000 \mathrm{lb})$ & 0.907 & $\begin{array}{l}\text { megagrams } \\
\text { (or "metric ton") }\end{array}$ & Mg (or "t") \\
\hline \multicolumn{5}{|c|}{ TEMPERATURE (exact degrees) } \\
\hline${ }^{\circ} \mathbf{F}$ & Fahrenheit & $\begin{array}{l}5(F-32) / 9 \\
\text { or }(F-32) / 1.8\end{array}$ & Celsius & ${ }^{\circ} \mathrm{C}$ \\
\hline
\end{tabular}




\section{Technical Report Documentation}

\begin{tabular}{|l|l|}
\hline 1. Report No. & 2. Government Accession No. \\
$B D K 85977-36$ &
\end{tabular}

A Tool for Assessing the Economic Impact of Spending on Public Transit

6. Performing Organization Code
3. Recipient's Catalog No.

\section{Author(s)}

Xuehao Chu, Ph.D.
8. Performing Organization Report No. NCTR 77941/BDK85 977-36/U.S.DOT DTRS98-G0032

10. Work Unit No. (TRAIS)

\section{Performing Organization Name and Address}

National Center for Transit Research

Center for Urban Transportation Research

University of South Florida

4202 East Fowler Avenue, CUT100, Tampa, FL 33620

11. Contract or Grant No.

\section{Sponsoring Agency Name and Address}

Research and Innovative Technology Administration

U.S. Department of Transportation, Mail Code RDT-30

1200 New Jersey Ave., SE, Room E33, Washington, DC 20590

Florida Department of Transportation, Research Center

605 Suwannee Street, MS 30, Tallahassee, FL 32399

14. Sponsoring Agency Code

\section{Supplementary Notes}

Supported by a grant from the Florida Department of Transportation and the U.S. Department of Transportation

16. Abstract

In this project, an Excel-based template tool was developed for transit agencies, local governments, and other stakeholders of public transit to estimate the economic impacts of spending on public transit. Features include the following:

- Uses input-output multipliers from the Regional Input-Output Modeling System (RIMS II) (U.S. Bureau of Economic Analysis) to capture the direct, indirect, and induced effects of spending on public transit in terms of gross output (sales), value added (regional gross domestic product, GDP), labor earnings, and jobs (person-years of full- and parttime employment) for any study area consisting of one or more spatially-contiguous counties.

- Explicitly considers whether spending originated from funds inside or outside the study area, whether spending was made inside or outside the study area, whether funds originated from borrowing, whether spending was for land acquisition, and the effect of full employment on estimated job impacts.

- Is designed for estimating the economic impacts of spending on transit primarily on existing service or on service expansion in an area that already has transit service; is applicable, with caution, to new transit services for areas that do not already have transit service.

- Use of the tool for any study area requires several type II final-demand multipliers from RIMS II and the following data specific to the study area: total spending for operations and maintenance, capital spending by project category, sources of funds for the spending, and geographic destinations of the spending; most of the required spending data for existing services can be derived from the National Transit Database.

- Presents the results separately for capital projects, operations and maintenance, and total spending; also presents results in terms of total impacts and unit impacts per dollar spent.

- Provides estimates of net economic impacts that may be considered as being created by the spending on transit and would not exist without the public transit service and related spending, and estimates of gross economic impacts that may be considered as being supported by the spending on transit.

This report discusses methodological factors, describes the tool and its use, and presents applications of the tool to Central Florida counties with urban public transit service.

17. Key Words

Public Transit, Capital Spending, Operation and Maintenance Spending, Economic Impacts, RIMS II, Multipliers, National Transit Database

19. Security Classification Unclassified
20.

Classification Unclassified
18. Distribution Statement

Available to the public through the National Technical Information Service (NTIS), 5285 Port Royal Road, Springfield, VA 22161, (703) 487-4650, http://www.ntis.gov, and through the NCTR website at http://www.nctr.usf.edu/
21. No. of Pages
22. Price 


\section{Acknowledgments}

Thanks to Brian Anderson of the Central Florida Regional Transportation Authority (LYNX), who provided summary information on the county of residence for LYNX employees. Thanks to John Zielinski, the Florida Department of Transportation (FDOT) Project Manager, for his guidance and patience. Thanks also to the following individuals who provided comments and suggestions:

- Steve Polzin, Center for Urban Transportation Research

- Santanu Roy, HDR Engineers, Inc.

- $\quad$ Lori Sellers and Natalie C. Suñer, GMB Engineers \& Planners, Inc.

- Joel Volinski, Center for Urban Transportation Research 


\section{Executive Summary}

\section{Introduction}

Debates on public investments in transit continue at the national, state, and local levels. To participate, government agencies and other stakeholders frequently need information on the benefits of transit in their communities. Most of these potential benefits are transportationrelated, including opportunities for mobility for those without alternative means of travel, reduced delays to car users, reduced energy use and pollutant emissions, improved safety to all roadway users, etc. Beyond these transportation benefits, however, local communities also want information on the economic impacts of spending on transit, i.e., how spending local resources on public transit impacts their local economy. To be effective, the information needs to be objective, current, and specific to the relevant local community. For the vast majority of agencies and stakeholders, obtaining data is difficult with existing tools and information. A simple tool with minimum data requirements would go a long way toward reducing this difficulty for agencies and stakeholders.

The primary objective of this research was to develop a simple tool for users to estimate the economic impacts of spending on transit. Expanding this tool for the transportation benefits of transit investments is a potential future research area. Available tools were reviewed. No tool was identified in Florida that can be used for estimating the economic impacts of spending on transit. Tools developed elsewhere are either designed for individual transit projects or extremely simplified and do not include the analysis options desired. Another objective of the current research was to apply this tool to the Central Florida region under the jurisdiction of District 5 of the Florida Department of Transportation.

\section{Summary}

This project developed an Excel-based template for transit agencies, local governments, and other stakeholders of public transit to estimate the economic impacts of spending on public transit with the following main features:

1. It is built on a commonly-used basic method for impact assessment of public spending. This basic method requires industry-specific multipliers that capture the full ripple effects of spending on transit.

2. It reflects the professional best practices for implementing this basic method. These best practices require data not only on the components of spending on transit in terms of capital vs. operations and maintenance (O\&M) and different categories of capital projects but also on the patterns of spending in terms of where the money is spent, where the money comes from, whether the money is borrowed, etc.

3. It is flexible in that it provides a range of options to meet the information needs that vary across communities and for different purposes within a community.

4. It is simple, easy to use, and requires minimum input data necessary for the first three design features. 
The tool is applicable to any given set of spending on transit as long as the required data are available either from observation or estimation and the application is proper relative to the limitations of the multipliers used. Therefore this tool does not preclude it from being applied to any specific type of spending on transit, including:

- Any mode of transit: commuter rail, light rail, bus rapid transit, paratransit, etc.

- Any nature of service: existing service, expansion of service, or planned new service

- Any type of spending: capital or O\&M

Local governments, metropolitan planning organizations (MPO), and transit agencies in individual communities can use the results from this tool to answer questions that the key decision makers of their communities may have about spending on transit and its economic impacts on the local economy.

The application of this tool to the individual counties in Central Florida with current urban transit services shows that cross-county differences in the economic impacts of total spending on transit are driven not only by the total amount of spending and the multiplier values but also the pattern of the total spending in terms of where the money is spent and where the money comes from. The primary driving factor for the total economic impacts created in a county by spending on transit is the share of the total spending on goods and services produced within the county using outside funds. The primary driving factor for the total economic impacts supported in a county by spending on transit is the share of the total spending on transit for goods and services produced within the county using both local and outside funds. For a given county, the economic impacts of the same amount of spending could be significantly different if the pattern of its funding source and the spending destinations differ from those implicit in the results presented in this report. For example, users of this tool should not try to estimate the economic impacts of future spending on transit from the economic impacts reported above. Instead, this tool should be applied separately to future spending on transit to re-estimate the likely economic impacts.

The tool is not designed to consider the transportation benefits of transit investments such as the improvement of someone's health as a result of their being able to reliably make medical appointments or the improvement in quality of life when someone is able to travel to socialize with the relative. Nor is it designed to estimate either the economic impacts of highway projects or the economic impacts of using funds for transit on highway projects. Rather, this tool is intended to provide an additional low-cost option for communities to get a fuller picture of the effects of spending their scarce resources for transit services in terms of the economic impacts on the local economy.

The next several sections provide more details about this research project and the tool developed from it in terms of the overall methodology used, the Excel-based tool, and the application to Central Florida. 


\section{Methodology}

The overall methodology for this research project consisted of several components, including a commonly-used method for impact assessment, the best practices used in implementing this commonly-used method in the tool, the flexiblity built into the tool, the data requirements, and the general applicability of the tool.

\section{The Basic Method}

The method of economic impact assessment used in this analysis, referred to as the "basic method" in this report, is not unique to the current research and involves concepts and techniques that are commonly used in estimating the economic impacts of public spending on transportation projects, educational institutions, sports facilities, etc.

One element of this basic method is that it states the economic impacts in terms of several measures of economic activity in the local economy, typically including:

- Output-represents the total gross sales in the economy

- Value Added-is comparable to gross domestic product (GDP) at the local level

- Earnings-represents labor income by workers

- Jobs-represents the number of jobs in person-years of employment

This basic method estimates the impacts of spending on transit in terms of these measures of the economy by tracing the path of an initial set of spending on transit throughout the local economy:

- Locally-produced goods and services purchased by the transit agency as part of the initial spending on transit.

- Ripple effects through the subsequent rounds of locally-produced goods and services purchased by local industries affected by the spending on transit.

- Ripple effects in terms of the change in economic activity resulting from the changes in spending by workers whose earnings are affected by the spending on transit.

Rather than relying on actually tracing this path for any specific set of spending on transit, the basic method uses multipliers to capture this path of effects of spending on transit. These multipliers are derived from detailed accounting tables that show the goods and servcies produced by each industry and the use of these goods and services by industries and consumers, governments, and investments. Base tables are constructed at the national level, and tables for individual study areas are derived by adjusting the national table to account for local supply conditions. Local industries may purchase some intermediate inputs from suppliers outside the region. 
These multipliers are made available for individual industries. For estimating the economic impacts of spending on transit O\&M, for example, one may use the multipliers derived for the industry of operating transit and ground passenger transportation. For this industry, the Jobs Multiplier shows a total change in local employment from spending $\$ 1$ million on transit O\&M.

Once the amount of spending on transit is known for a specific industry and the corresponding multipliers are obtained for this industry, the basic method is ready to estimate the economic impacts of this spending on transit. Consider spending on transit O\&M spending and its jobs impact for illustration: Jobs impacts $=0 \& M$ spending $\times$ Jobs Multiplier for the transit and ground passenger transportation industry.

\section{Best Practices}

It is a best practice to consider the pattern of spending on transit when estimating its economic impacts. The pattern of spending on transit characterizes the spending in terms of whether it is spent on locally-produced goods and services, the source of funds, whether the funds are borrowed, and whether any borrowed funds will be paid back with local funds. Most best practices require keeping track of this pattern and estimating the economic impacts separately for different parts of the total spending accordingly. Summarized in the "Net" column of Table E-1, the following are how this tool is built to treat the different parts of a given set of spending on transit in estimating its total economic impacts on the local economy of a study area:

- Spending state and/or federal assistance on goods and services produced outside the study area: Zero impacts if the assistance is not required to be paid back.

- Spending state and federal assistance on goods and services produced inside the study area: Positive impacts if the assistance is not required to be paid back, with the exact impacts for this portion of the total spending to be determined by applying it to appropriate multipliers.

- Spending local funds on locally produced goods and services: Approximately zero impacts, after accounting for the potential impacts of the local funds being spent for non-transit purposes in the study area.

- Spending local funds on goods and services produced outside the study area: Negative impacts, with the exact impacts for this portion of the total spending to be determined by applying it to appropriate multipliers.

- Spending borrowed funds for goods and services produced outside the study area: Zero impacts if the borrowed funds are to be paid back with state/fedeal assistance.

- Spending borrowed funds on goods and services produced inside the study area: Positive impacts if the borrowed funds are to be paid back with state/federal assistance, with the exact impacts for this portion of the total spending to be determined by applying it to appropriate multipliers. 
- Spending borrowed funds on goods and services produced inside the study area: Zero impacts if the borrowed funds are to be paid back with local funds.

- Spending borrowed funds on goods and services produced outside the study area: Negative impacts if the borrowed funds are to be paid back with local funds, with the exact impacts for this portion of the total spending to be determined by applying it to appropriate multipliers.

Table E-1. Qualitative Effects of Best Practices on Estimated Impacts

\begin{tabular}{|l|l|l|c|c|}
\hline \multirow{2}{*}{ Financing } & $\begin{array}{l}\text { Funds for Debt } \\
\text { Repayment }\end{array}$ & Spending Pattern & Net & Gross \\
\hline \multirow{3}{*}{$\begin{array}{l}\text { Non- } \\
\text { Financed }\end{array}$} & & Outside money spent outside & 0 & 0 \\
\cline { 2 - 5 } & & Outside money spent inside & + & + \\
\cline { 2 - 5 } & & Inside money spent inside & 0 & + \\
\hline \multirow{2}{*}{$\begin{array}{l}\text { Financed } \\
\text { (from } \\
\text { outside) }\end{array}$} & \multirow{2}{*}{ Outside money } & Inside money spent outside & - & 0 \\
\cline { 2 - 5 } & Inside money & Spent outside & - & 0 \\
\cline { 2 - 5 } & Spent inside & - & + \\
\cline { 2 - 5 } & Spent inside & - & 0 \\
\hline
\end{tabular}

\section{Minimum Input Data}

The basic method as described earlier and implemented in the tool requires data on multipliers that capture the full impacts of spending on transit through the ripple effects in the local economy both on the business side and on the household side. Using the basic method for impact assessment also requires separate data for capital and O\&M spending and separate data for different categories of capital projects. These different components of the total spending may require multipliers for different industries.

As discussed above, the best practices built into the tool further require data on the distribution of spending by where the money is spent, where the money comes from, and whether the money is borrowed and data on the distribution of debt repayments if any by where the money comes from.

The tool makes simplifying assumptions to minimize the input data to get the estimated impacts approximately correct while maintaining consistency with the best practices. Most are used to approximate the impacts of local funds if not being used for spending on transit.

The tool also pre-specifies several aspects of these required data to make the tool easier to use and these same specifications also reduce input data. These include:

- Using the National Transit Database (NTD) for spending data for existing services

- Relying on the Regional Input-Output Modeling System (RIMS II) of the U.S. Bureau of Economic Analysis for multipliers

- Pre-specifying categories of capital projects

- $\quad$ Pre-specifying the RIMS II industry for O\&M and for each category of capital projects 
If not already purchased for another purpose of the same study area, the required RIMS II multipliers must be purchased on a user-by-user basis from the RIMS II Online Order and Delivery System at https://www.bea.gov/regional/rims/rimsii/. The cost of the full set of RIMS II multipliers for each study area was \$275 in 2013.

\section{Flexibility}

It is not uncommon for different stakeholders to have different questions with regards to the economic impacts of spending on transit. To accommodate these varying questions the tool offers various options and measures:

- Type of Impacts-The tool estimates the economic impacts of spending on transit separately for each of four measures of economic activity: output, value added, earnings, and jobs for every application. Frequently, the economic impacts on jobs are of the most interest to local communities. The estimated impacts from this tool are the total impacts for all industries affected by the spending on transit considered. The total impacts cannot be meaningfully disaggregated for each of these affected industries.

- Type of Spending-The tool offers four options in estimating the economic impacts of spending on transit by type of spending: capital alone, O\&M alone, capital and $0 \& M$ separately, and capital and $0 \& M$ combined.

- Nature of Impacts-As the built-in best practices call for, the tool is designed primarily to estimate the "net" impacts of spending on transit in a given study area, which represent the impact on the local economy from spending outside funds inside the study area after accounting for the impact on the local economy from spending any inside funds alternatively on non-transit purposes. After appropriate multipliers are applied to the rows with a "+" or "-" in the "Net" column of Table E-1, the sum of that column gives the net impacts of the total spending considered.

To meet the desire for some communities to know the amount of economic activity supported by their spending on transit, this tool also provides estimates of the "gross" impacts of the same total spending on transit, which represents the impact on the local economy from spending transit funds from both outside sources and local sources without considering the impact of spending any local funds alternatively on non-transit purposes. The sum of column "Gross" in Table E-1 gives the total gross impacts of the total spending considered after appropriate multipliers have been applied to the rows with a "+."

- Total vs. Unit Impacts-The tool presents the estimated impacts for every application both in terms of "total impacts" expressed in units such as dollars and jobs and in terms of "unit impacts" calculated as the ratio of total impacts over the amount of spending on transit. The total impacts of a given set of spending may be used to indicate the size of the impact on the local economy. In contrast, the unit impacts may be used to indicate the rate-of-return of the same transit investment on the local economy. 
- Leveraging Effects-The tool also provides two measures of unit impacts for every application where local funds are used. One is given by the ratio of the total impacts of a given set of spending on transit over the total spending of funds from all sources. This is the default measure of unit impacts and may be referred to as the "regular unit impacts" for ease of reference. The other measure is given by the ratio of the same total impacts of a given set of spending on transit over only the portion of the total spending using local funds. For ease of reference, this alternative measure may be referred to as the "leveraged unit impacts." For a given set of transit spending considered, the measure of leveraged unit impacts will necessarily be the same or larger than the measure of regular unit impacts, reflecting the leveraging effect of spending local resources by crediting all the impacts to the local resources. Local resources include government, agency-generated, and transitdedicated revenues. In a formula format, these two measures are:

- Regular Unit Impacts = Total Impacts / Total Spending on transit using local and outside funds

- Leveraged Unit Impacts = Total Impacts / Spending on transit using local funds only

\section{Applicability}

The tool is not designed to consider the transportation benefits of transit investments such as the improvement in someone's health as a result of their being able to reliably make medical appointments or the improvement in quality of life when someone is able to travel to socialize with the relative. Nor is it designed to estimate either the economic impacts of highway projects or the economic impacts of using funds for transit on highway projects.

The tool is designed primarily to estimate the economic impacts of spending on transit for cases of existing service where all required input data are readily available and specific to the study area. The tool may also be used to estimate the economic impacts of spending on transit for other situations where some portions of the required data are either estimated or borrowed from other sources with some degree of uncertainty. Extreme caution is called for some of these cases.

The final decision of applying the tool for any particular case should also consider whether the potential application is proper relative to the limitations of RIMS II multipliers. For example, the study area must consist of one or more spatially-contiguous counties. In addition, the study area should be properly chosen so that it is where affected workers live and spend most of their earnings. Also, the magnitude of spending on transit should not be so large as to alter the base structure of the local economy.

The tool is applicable to any given set of spending on transit as long as the required data are available either from observation or estimation and the application is proper relative to the limitations of RIMS II multipliers. Therefore this tool does not preclude it from being applied to any specific type of spending on transit, including:

- Any mode of transit: commuter rail, light rail, bus rapid transit, paratransit, etc. 
- Any nature of service: existing service, expansion of service, or planned new service

- Any type of spending: capital or O\&M

The tool can also be used to conduct sensitivity analyses with respect to the input data on the amount and pattern of spending by estimating the impacts for alternative values of respective input data. One might want to do this in cases where some of the input data are estimated and there might be uncertainty in some of these estimates.

\section{The Excel-Based Tool}

The Excel workbook for this tool contains four tabs:

- COVER - introduces the tool, summarizes its main features, and includes a PDF version of this report inserted into the worksheet serving as the user guide.

- INPUT - is where the required input data are entered for estimating the economic impacts of spending on public transit.

- CALCULATIONS - takes all input data provided in INPUT, accounts for the best practices in implementing the basic method, and calculates total impacts and summarizes total spending by source of funds and destination of spending. This tab is hidden from the user.

- RESULTS - presents the estimated impacts for various options.

\section{Applications to Central Florida}

In this research project, the tool was applied to District 5 of the Florida Department of Transportation. Decision makers in Central Florida asked specific questions about spending on transit and its economic impacts in the region. Most of these questions relate to the job impacts of spending on transit. Table E-2 lists these questions. Each question has been matched to a particular measure of economic impacts available in the tool. Instead of presenting results for all measures of impact available from the tool, this matching allows the applications to focus on the most relevant results for this region.

Table E-2. Local Questions and Matching Impact Measures

\begin{tabular}{|l|l|}
\hline \multicolumn{1}{|c|}{ Question } & \multicolumn{1}{c|}{ Impact Measure } \\
\hline $\begin{array}{l}\text { 1. What does local bus service provide to the } \\
\text { community economically? }\end{array}$ & Total gross impacts of total spending \\
\hline $\begin{array}{l}\text { 2. What are the economic impacts of adding, } \\
\text { improving, or removing this service? }\end{array}$ & Total net Impacts of total spending \\
\hline $\begin{array}{l}\text { 3. For every } \$ 1 \text { million invested in maintenance and } \\
\text { operations, what is the number of jobs supported? }\end{array}$ & $\begin{array}{l}\text { Unit gross impacts of total O\&M spending } \\
\text { using all funds }\end{array}$ \\
\hline $\begin{array}{l}\text { 4. For every } \$ 1 \text { million invested in capital, what is the } \\
\text { number of jobs supported? }\end{array}$ & $\begin{array}{l}\text { Unit gross impacts of total capital } \\
\text { spending using all funds }\end{array}$ \\
\hline $\begin{array}{l}\text { 5. For every } \$ 1 \text { million invested in maintenance and } \\
\text { operations, what is the number of jobs created? }\end{array}$ & $\begin{array}{l}\text { Unit net impacts of total O\&M spending } \\
\text { using all funds }\end{array}$ \\
\hline $\begin{array}{l}\text { 6. For every } \$ 1 \text { million invested in capital, what is the } \\
\text { number of jobs created? }\end{array}$ & $\begin{array}{l}\text { Unit net impacts of total capital spending } \\
\text { using all funds }\end{array}$ \\
\hline
\end{tabular}




\section{Existing Urban Transit Service}

The application focused on counties with existing urban transit services. Both Flagler and Sumter counties provide rural transit service and report their data to the rural portion of the NTD, but the required input data are not fully available. Table E-3 summarizes the existing urban transit services in terms of the counties served, modes operated, and the annual total revenue vehicle miles provided.

Table E-3. Summary of Transit Agencies in District 5

\begin{tabular}{|l|l|l|l|}
\hline Transit Agency & Counties Served & Modes Operated & $\begin{array}{l}\text { Revenue Vehicle } \\
\text { Miles Provided* }\end{array}$ \\
\hline LakeXpress & Lake & $\begin{array}{l}\text { Fixed-route bus } \\
\text { Demand response }\end{array}$ & $2,229,240$ \\
\hline LYNX Transit & $\begin{array}{l}\text { Orange } \\
\text { Osceola } \\
\text { Seminole }\end{array}$ & $\begin{array}{l}\text { Fixed-route bus } \\
\text { Demand response } \\
\text { Vanpool }\end{array}$ & $24,583,550$ \\
\hline $\begin{array}{l}\text { Space Coast Area } \\
\text { Transit (SCAT) }\end{array}$ & Brevard & $\begin{array}{l}\text { Fixed-route bus } \\
\text { Demand response } \\
\text { Vanpool }\end{array}$ & $4,124,518$ \\
\hline $\begin{array}{l}\text { SunTran } \\
\text { County of Volusia dba }\end{array}$ & Volusia & $\begin{array}{l}\text { Fixed-route bus } \\
\text { Demand response }\end{array}$ & 449,019 \\
\hline $\begin{array}{l}\text { VOTRAN } \\
\text { *2007 NTD for SunTran, 2011 NTD for } \\
\text { http://www.ftis.org/intdas.html. }\end{array}$ & $\begin{array}{l}\text { Fixed-route bus } \\
\text { Demand response } \\
\text { Vanpool agencies. Data accessed using INTDAS at }\end{array}$ & $4,934,537$ \\
\hline
\end{tabular}

\section{Input Data}

\section{Spending on Transit}

This application relied primarily on the NTD for most of the required input data. The data represent average annual spending over the 2005-2007 period for SunTran and over the 2009-2011 period for other agencies. The data items include:

- Average annual total O\&M spending for each agency-the LYNX total O\&M spending was attributed to the three counties according to the share of LYNX employees residing in each county.

- Average annual total capital spending by project category for each agency-the LYNX data were attributed to the three counties as follows: $80 \%$ to Orange, $10 \%$ to Osceola, $10 \%$ to Seminole.

- Distribution of total spending by source of funds for each agency-the LYNX distribution is applied to each of the three counties served. 
In addition, the application to Central Florida used the default distribution of spending across spending destinations by spending type (capital vs. O\&M) and project category for capital spending.

Rather than presenting each piece of required input data for spending on transit for each application county, Table E-4 summarizes the annual total spending on transit by source of funds and spending destination for each county both in dollar amounts and in percent distributions.

Table E-4. Summary of Annual Average Spending on Transit

\begin{tabular}{|c|c|c|c|c|c|c|c|c|c|c|}
\hline \multirow{3}{*}{\begin{tabular}{l|}
$\$$ vs. $\%$ \\
Source of \\
Funds \\
Spending \\
Destination \\
\end{tabular}} & \multicolumn{5}{|c|}{ Amount of Spending (millions, 2011\$) } & \multicolumn{5}{|c|}{ \% Distribution } \\
\hline & \multicolumn{2}{|c|}{$\begin{array}{c}\text { Outside } \\
\text { Study Area }\end{array}$} & \multicolumn{2}{|c|}{$\begin{array}{c}\text { Inside } \\
\text { Study Area }\end{array}$} & \multirow[b]{2}{*}{ Total } & \multicolumn{2}{|c|}{$\begin{array}{c}\text { Outside } \\
\text { Study Area }\end{array}$} & \multicolumn{2}{|c|}{$\begin{array}{c}\text { Inside } \\
\text { Study Area }\end{array}$} & \multirow[b]{2}{*}{ Total } \\
\hline & $\begin{array}{c}\text { Inside } \\
\text { Study } \\
\text { Area }\end{array}$ & \begin{tabular}{|c|} 
Outside \\
Study \\
Area
\end{tabular} & $\begin{array}{c}\text { Inside } \\
\text { Study } \\
\text { Area }\end{array}$ & $\begin{array}{c}\text { Outside } \\
\text { Study } \\
\text { Area }\end{array}$ & & $\begin{array}{l}\text { Inside } \\
\text { Study } \\
\text { Area }\end{array}$ & $\begin{array}{c}\text { Outside } \\
\text { Study } \\
\text { Area }\end{array}$ & $\begin{array}{l}\text { Inside } \\
\text { Study } \\
\text { Area }\end{array}$ & $\begin{array}{l}\text { Outside } \\
\text { Study } \\
\text { Area }\end{array}$ & \\
\hline Column & [1] & [2] & [3] & [4] & [5] & [6] & [7] & [8] & [9] & [10] \\
\hline $\mathrm{Bre}$ & & & $\$ 3.72$ & & & 85 & $2.3 \%$ & 26 & $\%$ & \\
\hline Lak & & & & & & $55.7 \%$ & $\%$ & $\%$ & $\%$ & \\
\hline Mar & & & & & 2 & $47.8 \%$ & $30.5 \%$ & $9.9 \%$ & $2.2 \%$ & \\
\hline Orang & 4.57 & $\$ 11.68$ & $\$ 42.67$ & $\$ 4.80$ & $\$ 83.72$ & $29.3 \%$ & $14.0 \%$ & $51.0 \%$ & $5.7 \%$ & $100 \%$ \\
\hline Osceola & $\$ 5.60$ & $\$ 1.74$ & $\$ 10.66$ & $\$ 1.19$ & $\$ 19.19$ & $29.2 \%$ & $9.1 \%$ & $55.5 \%$ & $6.2 \%$ & $100 \%$ \\
\hline Seminole & .53 & $\$ 1.51$ & $\$ 6.30$ & $\$ 0.71$ & $\$ 12.05$ & $29.3 \%$ & $12.5 \%$ & $52.3 \%$ & $5.9 \%$ & $100 \%$ \\
\hline Volusia & $\$ 6.78$ & $\$ 3.27$ & $\$ 10.51$ & $\$ 1.17$ & $\$ 21.72$ & $31.2 \%$ & $15.1 \%$ & $48.4 \%$ & $5.4 \%$ & $100 \%$ \\
\hline
\end{tabular}

\section{Multipliers}

This research project ordered one set of RIMS II multipliers for each of the counties in District 5. Table E-5 shows the values of Type II multipliers for the most relevant two RIMS II industries for each application county.

Table E-5. Type II Multipliers from RIMS II for Jobs

\begin{tabular}{|l|l|l|}
\hline County & Construction & $\begin{array}{c}\text { Transit and Ground } \\
\text { Passenger } \\
\text { Transportation }\end{array}$ \\
\hline Orange & 10.5463 & 15.1392 \\
\hline Osceola & 8.4754 & 10.9550 \\
\hline Seminole & 9.0224 & 12.4300 \\
\hline Lake & 10.5612 & 9.6961 \\
\hline Volusia & 14.5022 & 18.8848 \\
\hline Brevard & 14.8401 & 19.2121 \\
\hline Marion & 14.4306 & 19.0602 \\
\hline
\end{tabular}

\section{Selected Results}

Total Impacts

Table E-6 presents the estimated total gross impacts of total spending for providing all urban public transit service on an annual basis for each study county. These results can help answer Question 1 in Table E-2, what does local transit service provide to the 
community economically? Or, asked differently, how much of the local economy is supported by the annual spending on transit in the community? The cross-county difference in these gross total impacts is driven mainly by two factors. One is the total spending using outside funds on goods and services produced inside each county, which is the sum of columns (1) and (3) of Table E-4. The other factor is the multipliers as shown in Table E-5 for two main RIMS II industries.

Table E-6. Total Gross Impacts of Total Spending

\begin{tabular}{|l|l|l|l|l|}
\hline County & $\begin{array}{l}\text { Output } \\
\text { (millions, } \\
\mathbf{2 0 1 1} \mathbf{\text { ) }}\end{array}$ & $\begin{array}{l}\text { Value Added } \\
\text { (millions, } \\
\mathbf{2 0 1 1} \mathbf{\$})\end{array}$ & $\begin{array}{l}\text { Earnings } \\
\text { (millions, } \\
\mathbf{2 0 1 1} \mathbf{\text { ) }}\end{array}$ & $\begin{array}{l}\text { Jobs } \\
\text { (person- } \\
\text { years) }\end{array}$ \\
\hline Brevard & $\$ 16.99$ & $\$ 7.39$ & $\$ 5.24$ & 201 \\
\hline Lake & $\$ 7.07$ & $\$ 2.81$ & $\$ 1.26$ & 50 \\
\hline Marion & $\$ 2.94$ & $\$ 1.28$ & $\$ 0.89$ & 34 \\
\hline Orange & $\$ 125.06$ & $\$ 57.66$ & $\$ 27.37$ & 997 \\
\hline Osceola & $\$ 22.94$ & $\$ 9.40$ & $\$ 4.46$ & 177 \\
\hline Seminole & $\$ 16.89$ & $\$ 7.60$ & $\$ 3.28$ & 120 \\
\hline Volusia & $\$ 28.79$ & $\$ 12.54$ & $\$ 8.38$ & 322 \\
\hline
\end{tabular}

Table E-7 presents the estimated total net impacts of total spending for providing all urban public transit service on an annual basis for each study county. These results can help answer Question 2 in Table E-2, what is the economic impact of removing the transit service? Or, asked differently, how much of the local economy is created by the annual spending on transit in the community? Similarly, the cross-county difference in total net impacts is driven mainly by two factors. One is the same multipliers in Table E-5 for two main RIMS II industries as used in estimating the total gross impacts. The other factor is that portion of the total spending that was made using outside funds on goods and services produced within that county, which is summarized in column (1) of Table E-4.

Table E-7. Total Net Impacts of Total Spending

\begin{tabular}{|l|l|l|l|l|}
\hline County & $\begin{array}{l}\text { Output } \\
\left(\begin{array}{l}\text { millions, } \\
\mathbf{2 0 1 1} \$ \mathbf{)}\end{array}\right.\end{array}$ & $\begin{array}{l}\text { Value Added } \\
\text { (millions, } \\
\mathbf{2 0 1 1} \mathbf{\$})\end{array}$ & $\begin{array}{l}\text { Earnings } \\
\text { (millions, } \\
\mathbf{2 0 1 1} \$ \mathbf{)}\end{array}$ & $\begin{array}{l}\text { Jobs } \\
\text { (person- } \\
\text { years) }\end{array}$ \\
\hline Brevard & $\$ 10.71$ & $\$ 4.63$ & $\$ 3.32$ & 127 \\
\hline Lake & $\$ 5.24$ & $\$ 2.06$ & $\$ 0.93$ & 37 \\
\hline Marion & $\$ 2.03$ & $\$ 0.88$ & $\$ 0.62$ & 24 \\
\hline Orange & $\$ 40.28$ & $\$ 18.16$ & $\$ 8.93$ & 320 \\
\hline Osceola & $\$ 7.02$ & $\$ 2.74$ & $\$ 1.39$ & 55 \\
\hline Seminole & $\$ 5.38$ & $\$ 2.36$ & $\$ 1.06$ & 38 \\
\hline Volusia & $\$ 10.28$ & $\$ 4.37$ & $\$ 3.04$ & 115 \\
\hline
\end{tabular}

Regular Unit Impacts

To answer Questions 3-6 in Table E-2, Table E-8 presents the estimated regular unit impacts on jobs, which are given as the ratio of total job impacts over total spending considered. For each county, separate results are presented, depending on whether the impacts are net or gross and whether the spending is O\&M or capital. 
Table E-8. Unit Impacts on Jobs Per \$1 Million Spending of All Funds

\begin{tabular}{|l|l|l|l|l|}
\hline \multirow{2}{*}{ County } & \multicolumn{2}{|l|}{ Unit Gross Impacts } & \multicolumn{2}{l|}{ Unit Net Impacts } \\
\cline { 2 - 5 } & O\&M & Capital & O\&M & Capital \\
\hline Brevard & 17.3 & 2.5 & 10.6 & 2.5 \\
\hline Lake & 8.7 & 0.1 & 6.5 & 0.1 \\
\hline Marion & 17.2 & 2.2 & 11.6 & 2.1 \\
\hline Orange & 13.6 & 3.4 & 3.9 & 3.2 \\
\hline Osceola & 9.9 & 2.7 & 2.9 & 2.5 \\
\hline Seminole & 11.2 & 2.9 & 3.2 & 2.7 \\
\hline Volusia & 17.0 & 3.8 & 5.6 & 3.8 \\
\hline
\end{tabular}

One observation from Table E-8 is that the net and gross unit impacts differ significantly across counties for O\&M spending but are similar for capital spending. The key is in the proportion of the spending that uses local resources and is spent locally. This proportion of the spending supports jobs but does not create jobs in a county. Specifically, this proportion is much greater for O\&M spending than for capital spending.

Another observation is that the rate-of-return is much higher for O\&M spending than for capital spending. The reason is not necessarily because O\&M spending is more productive in supporting or creating jobs than capital spending. Rather, this is because O\&M spending and capital spending differ dramatically in where the funds come from and where they are spent. Specifically, a significant portion of capital spending for each county is made using outside funds on goods and services produced outside the study area, and this portion does not support or create any jobs locally. On the other hand, this portion for each county is small for O\&M spending.

Leveraged Unit Impacts

The results in Table E-8 help answer Questions 3-6 in Table E-2 relative to the spending of both outside and inside funds. To help answer these questions relative to the spending of local funds only, the bars in Figure E-1 show the leveraged unit net impacts on jobs, i.e., total jobs created per $\$ 1$ million spending of local funds. These results vary dramatically across the counties. Besides differences in the multipliers used, the following are three other factors contributing to these cross-county differences:

- Share of total spending within each county using outside funds (column [6])

- Share of total spending outside each county using local funds (column [9])

- Share of total spending using local funds (sum of columns [8]-[9])

The leveraged job impacts increase with larger values of the share of total spending locally using outside funds. In contrast, it decreases with larger values of the other two shares, especially the share of total spending using local funds. 


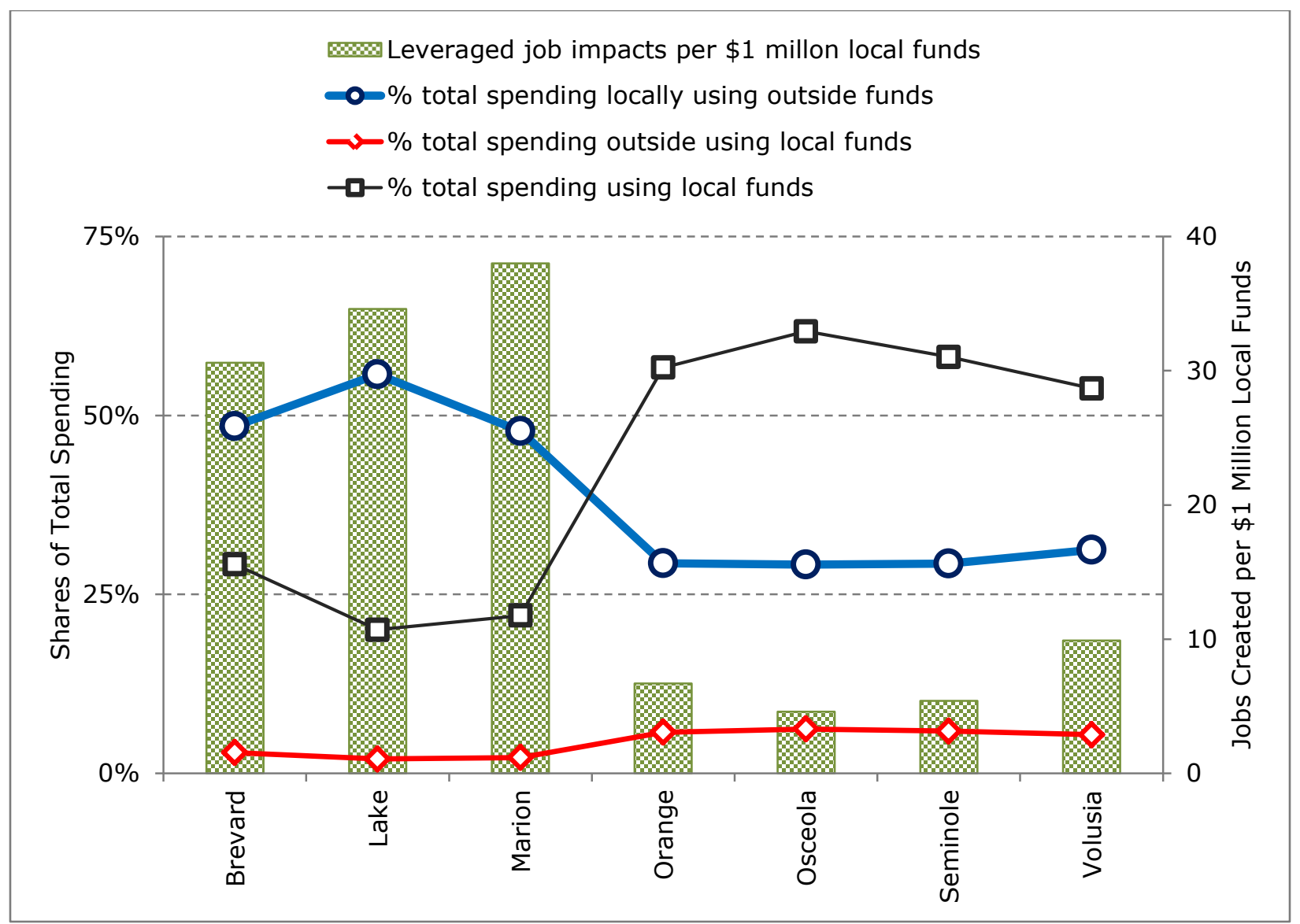

Figure E-1. Spending Shares and Leveraged Unit Impacts in Jobs Created 


\section{Table of Contents}

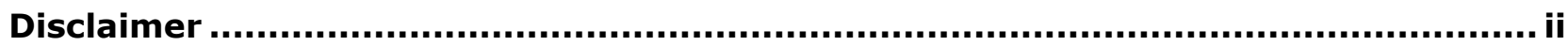

Metric Conversion ..................................................................................................... iii

Technical Report Documentation...................................................................... iv

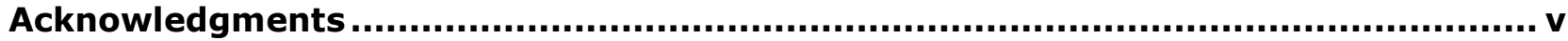

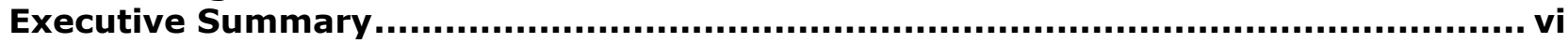

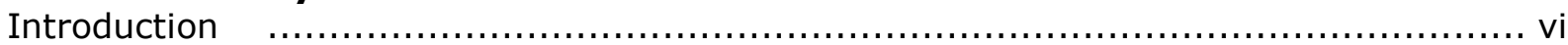

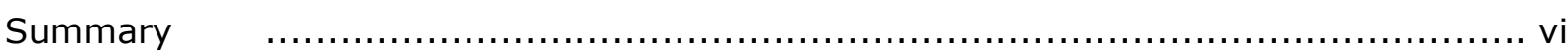

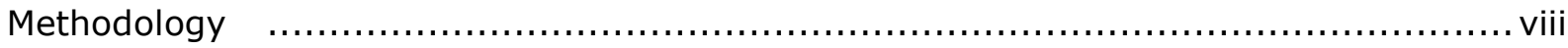

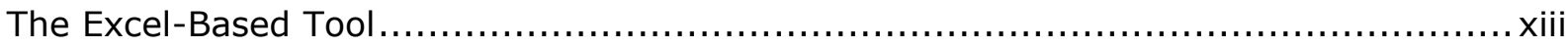

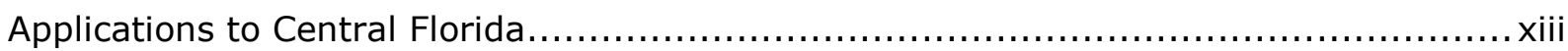

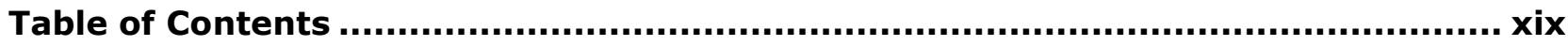

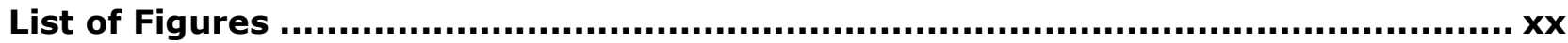

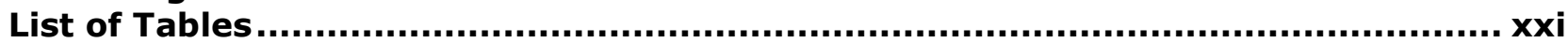

Chapter 1 - Introduction ........................................................................................ 6

Chapter 2 - Design Features ............................................................................ 9

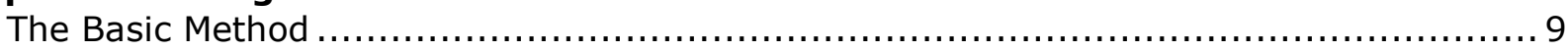

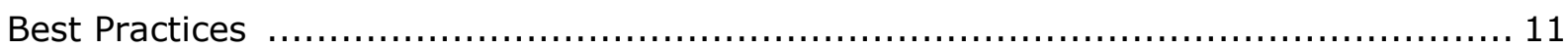

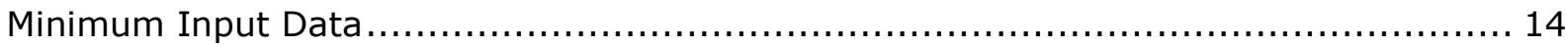

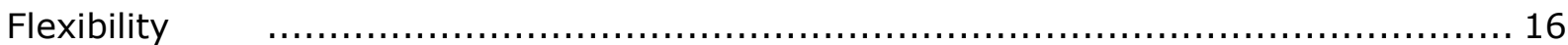

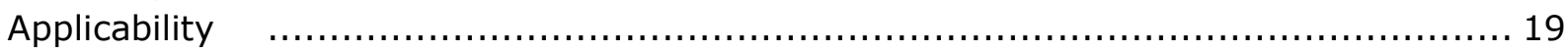

Chapter 3 - Excel-Based Tool ........................................................................... 24

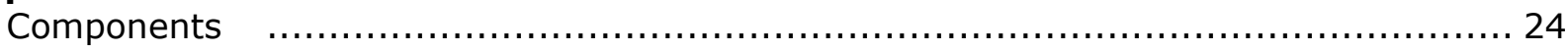

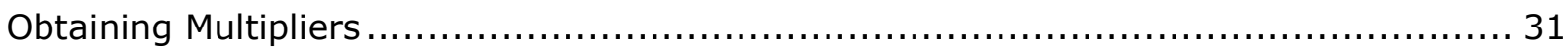

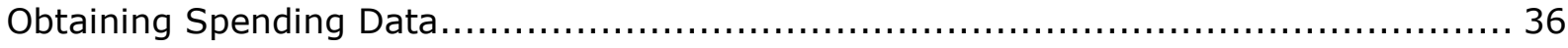

Chapter 4 - Applications to Central Florida ................................................. 45

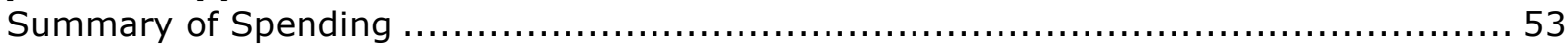

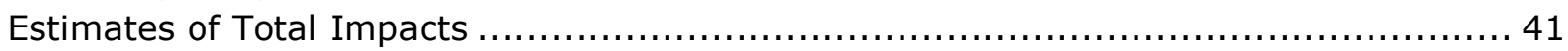

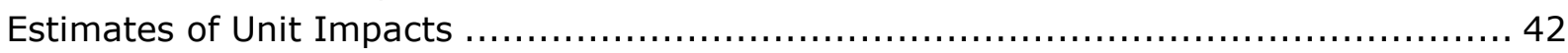

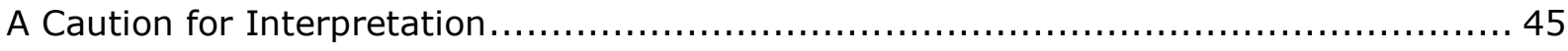

Future Applicability to Central Florida.................................................... 45

Chapter 5 - Conclusions ...................................................................................... 46

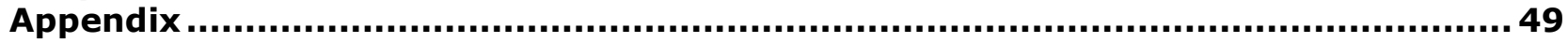

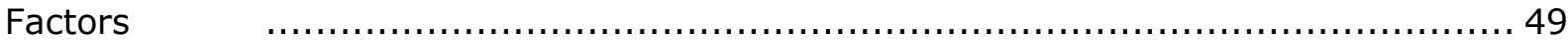

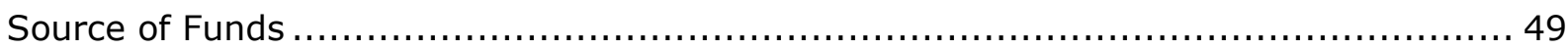

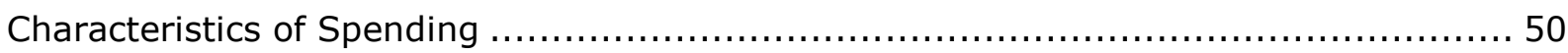

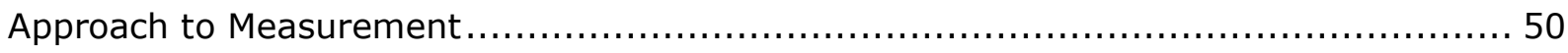

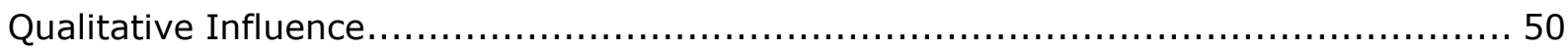

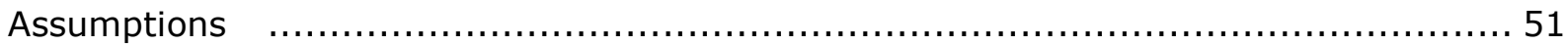




\section{List of Figures}

Figure E-1. Spending Shares and Leveraged Unit Impacts in Jobs Created.................... xviii

Figure 2-1. Illustration of Differences between Net and Gross Impacts ....................... 18

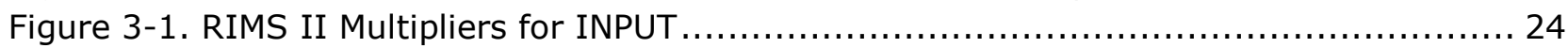

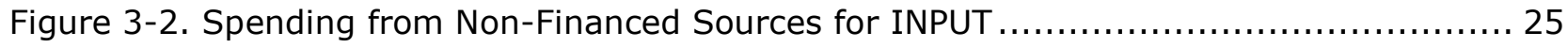

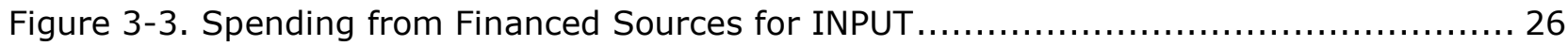

Figure 3-4. Source of Funds Used for Debt Payments for INPUT ............................ 26

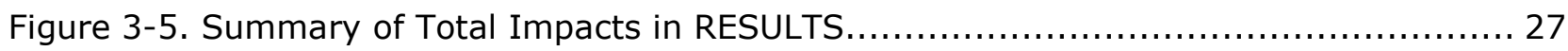

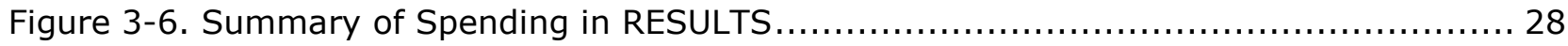

Figure 3-7. Summary of Unit Impacts for Spending of All Sources in RESULTS ................. 29

Figure 3-8. Summary of Unit Impacts for Spending of Inside Funds in RESULTS............... 30

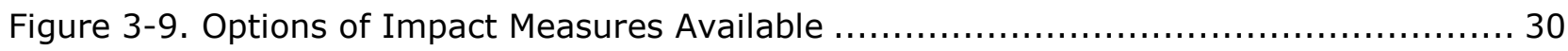

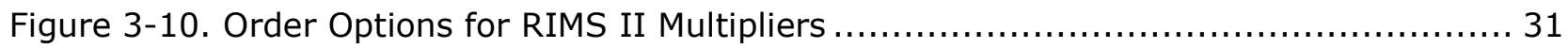

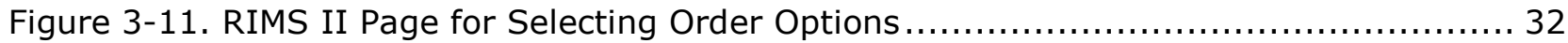

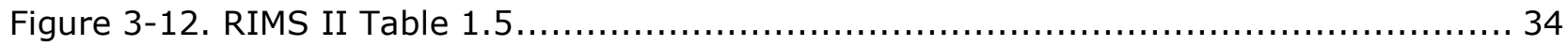

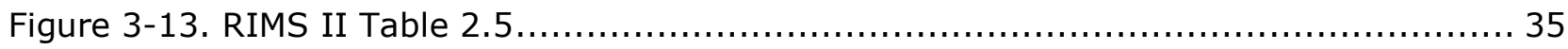

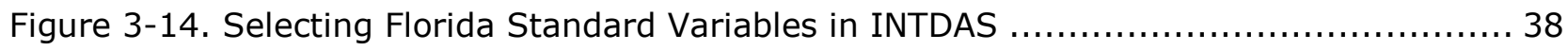

Figure 3-15. Selecting Year, Mode, Agency, and Service Type in INTDAS ..................... 40

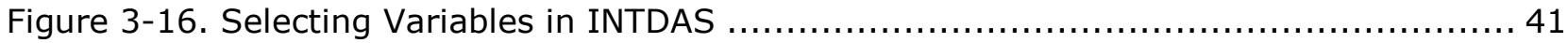

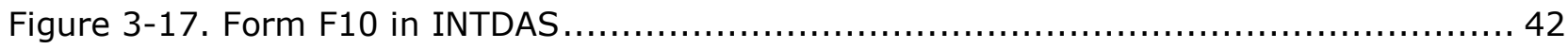

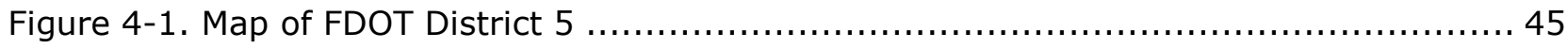

Figure 4-2. Matched Impact Measures for Central Florida Applications ........................ 47 


\section{List of Tables}

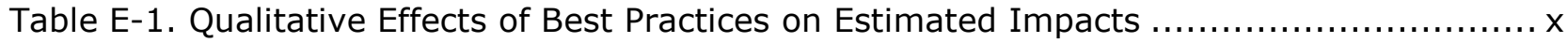

Table E-2. Local Questions and Matching Impact Measures ...................................

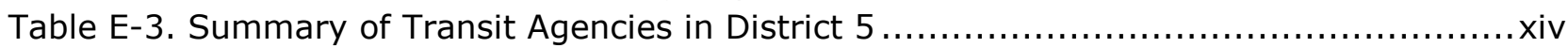

Table E-4. Summary of Annual Average Spending on Transit ................................ XV

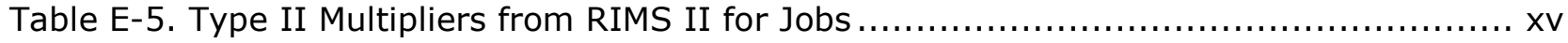

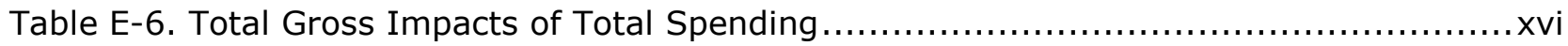

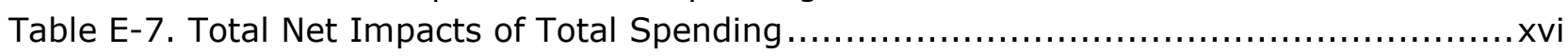

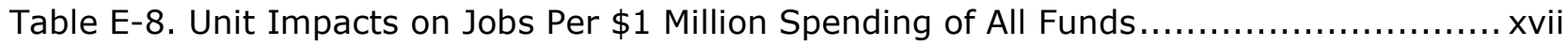

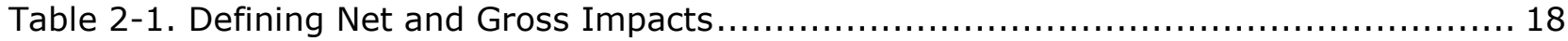

Table 3-1. Default Distributions of Capital Spending by Destination ......................... 43

Table 3-2. Distribution of Debt Repayments for All Agencies in 2010 NTD................... 44

Table 3-3. Distribution of Spending on Transit for All Agencies in 2010 NTD .................44

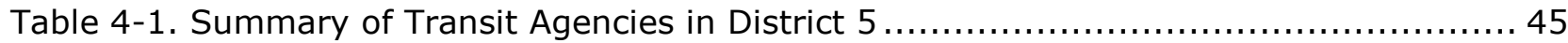

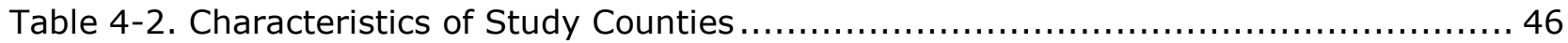

Table 4-3. Matching Study Questions and Impact Measures ................................ 47

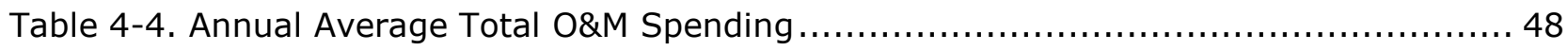

Table 4-5. Annual Average Capital Spending by Project Category $(2011 \$) \ldots \ldots \ldots \ldots \ldots \ldots \ldots . \ldots . \ldots . \ldots 49$

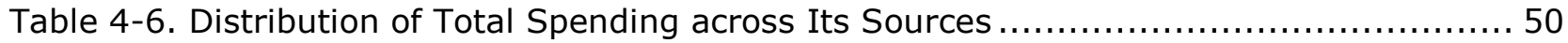

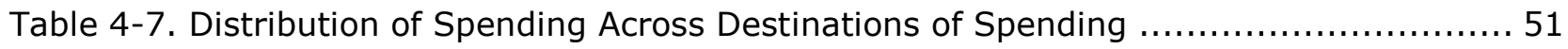

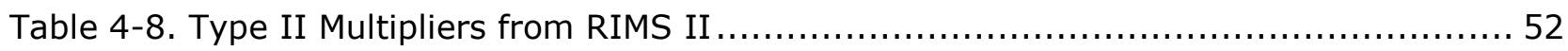

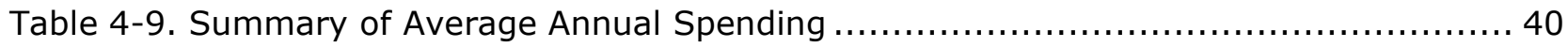

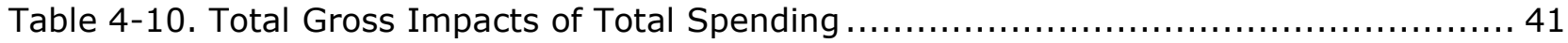

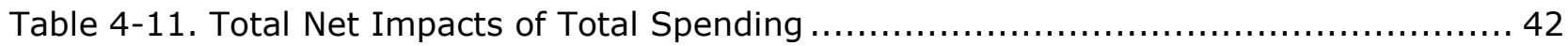

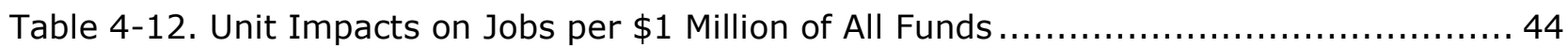

Table 4-13. Unit Impacts of Total Spending on Jobs per $\$ 1$ Million of Local Funds............ 44

Table A-1. Matrix of Methodological Factors and Their Qualitative Effects .................... 49 


\section{Chapter 1 - Introduction}

Debates on public investments in transit continue at the national, state, and local levels. To participate, government agencies and other stakeholders of public transit frequently need information on the benefits of public transit in their communities. To be effective, the information needs to be objective, current, and specific to the relevant local community. For the vast majority of agencies and stakeholders, obtaining these data is difficult with existing tools and information.

Some local agencies and stakeholders have used their already-limited budgets to fund studies of transit's economic and community benefits, and others have relied primarily on general information that is often out-of-date and specific to a much larger geography. For example, the American Public Transportation Association (APTA) funded several studies to assess transit benefits at the national level, and most agencies and stakeholders have used the information from these studies and from other state-level studies as they participate in discussions in their local communities. However, the information developed for larger geographies is of somewhat limited relevance for addressing questions in individual communities. Furthermore, the information developed for larger geographies can be seriously misleading for local communities because the larger geographies and local communities differ not only in the pattern of industry supply conditions but also in the pattern of spending on transit in terms of funding sources and spending destinations.

To help reduce this difficulty and advance the state of practice, this research effort developed an Excel-based template for transit agencies, local governments, and other stakeholders of public transit to estimate the economic impacts of spending on public transit with the following main features:

1. It is built on a commonly-used basic method for impact assessment of public spending. This basic method requires industry-specific multipliers that capture the full ripple effects of spending on transit.

2. It reflects the professional best practices for implementing this basic method. These best practices require data not only on the components of spending on transit in terms of capital vs. operations and maintenance (O\&M) and different categories of capital projects but also on the patterns of spending in terms of where the money is spent, where the money comes from, whether the money is borrowed, etc.

3. It is flexible in that it provides a range of options to meet the information needs that vary across communities and for different purposes within a community.

4. It is simple, easy to use, and requires minimum input data necessary for the first three design features.

Local governments, metropolitan planning organizations (MPO), and transit agencies in individual communities can use the results from this tool to answer questions that the key decision makers of their communities may have about spending on transit and its economic impacts on the local economy. The following are the types of questions that can be answered with the results from this tool: 
- What does local transit service provide to the community economically?

- What is the economic impacts of improving this service?

- What is the economic impacts of removing this service?

- For every $\$ 1$ million of local, state, and federal funds spent for transit O\&M, how many jobs are supported?

- For every $\$ 1$ million of local, state, and federal funds spent for transit O\&M, how many jobs are created?

- For every $\$ 1$ million of local, state, and federal funds invested in transit capital projects, how many jobs are supported?

- For every $\$ 1$ million of local, state, and federal funds invested in transit capital projects, how many jobs are created?

- For every $\$ 1$ million of local funds spent on public transit, how many jobs are supported?

- For every $\$ 1$ million of local funds spent on public transit, how many jobs are created?

A broad review of available tools was conducted as part of this research. No tool is available in Florida that can be used for estimating transit's economic impacts. In 2009, the Michigan Department of Transportation developed an Excel tool to measure transit's economic benefits, including the economic impacts of spending on transit, but it is specific to Michigan and not applicable to other communities. In addition, it does not provide the many analysis options desired for the tool, and these options are essential for meeting the varying need of different communities. Report 78 of the Transit Cooperative Research Program (TCRP), "Estimating the Benefits and Costs of Public Transit Projects: A Guidebook for Practitioners," includes a set of spreadsheet templates for measuring the economic impacts of individual transit projects. The tool from this project was designed to measure the economic impacts for spending on transit service in an aggregate geography (i.e., counties, regions, etc.). These templates are extremely simplified and does not include the analysis options that are addressed by the tool developed in this project.

Potential users of this tool include transit agencies, local governments, and other public and private stakeholders wishing to assess the annual economic impacts of public transit that are relevant and specific for their particular situations. The objective, current, and community-specific information from the tool will better inform policy discussion and support better policy decisions and greatly reduce the resources needed to produce such information at the local level.

Public transit can have a wide range of potential benefits, as described in TCRP Report 78. Many potential benefits are transportation-related, including opportunities for mobility for those without alternative means of travel, reduced delays to car users, reduced energy use and pollutant emissions, improved safety to all roadway users, etc. Most existing methods for estimating these potential benefits focus on effects of individual transit projects rather 
than on an entire geography; as a result, they cannot be easily used for the tool because they require more information with no uniform source of data available. For these reasons, the tool does not evaluate the potential transportation benefits of providing transit services; rather, it focuses on the economic impacts of spending related to providing transit services.

This tool is intended to supplement information about the benefits of transit investments in public policy debates and decision-making. Information on the economic impacts is intended to be additional information to further support decision-making. The tool provides an additional low-cost option for communities to get a fuller picture of the effects of spending their scarce resources in terms of the economic impacts on the local economy.

The remainder of this report is organized into four chapters. Chapter 2 discusses the design features and estimation methodology for the tool. Chapter 3 describes the Excel-based tool and its use. Chapter 4 applies the tool to each Central Florida county that has existing urban public transit service. Chapter 5 concludes the report. 


\section{Chapter 2 - Design Features}

This research project develops an Excel-based tool for assessing the economic impacts of spending on transit with the following design features:

1. Incorporates a basic method for impact assessment of public spending

2. Reflects the best professional practices of implementing this basic method

3. Requires modest input data

4. Is flexible and provides a range of options for measurement and presentation

Each of these design features of the tool is discussed in a separate section. In addition, the final section discusses the tool's applicability, which is defined by these four design features.

\section{The Basic Method}

The basic method itself is not unique to the current research and involves concepts and techniques that are commonly used in estimating the economic impact of public spending on transportation projects, educational institutions, sports facilities, etc.

One element of this commonly-used basic method is that it states the economic impacts in terms of several measures of economic activity in the local economy, typically including output, value added, labor earnings, and jobs:

- Output represents the total gross sales in the economy.

- Value Added is comparable to gross domestic product (GDP) at the regional level.

- Earnings represent labor income by workers.

- Jobs represent the number of jobs in person-years of employment.

This basic method estimates the impacts of spending on transit in terms of these measures of the economy by tracing the path of spending throughout the local economy:

- A portion of the spending on transit will be on transit workers living in the study area, a portion will be spent on goods and services produced by local firms, and a portion will be spent outside the study area (known as leakage) for both goods and services and for wages to transit employees residing outside the study area. The portions spent inside the study area for both goods and services and for wages to transit employees is typically referred to as the "direct effect" because it represents the purchases of goods and services by the transit agency directly.

- A portion of the money spent on the local goods and services will be produced by the local firms, generating first-round subsequent purchases of goods and services. The local businesses providing those goods and services in the first round will spend portions of it again on purchasing other local goods and services, as well as wage payments to workers in the study area. Each successive round of expenditures 
diminishes in magnitude due to leakage. This is typically referred to as the "indirect effect." But it is sometimes called the "inter-industry" effect because it represents the change in economic activity resulting from the subsequent rounds of goods and services purchased by local industries affected by the spending on transit.

- Parallel to the ripple effects on the business side of the economy, there are ripple effects on the household side. As transit workers, employees of the local suppliers to the transit agency, and employees of all other local firms in the ripple effects on the busines side are paid, they are going to spend some of the earnings to buy local consumer goods and services, inducing additional business sales and earning payments to workers. This is typically referred to as the "induced effect" and is sometimes called the "household-spending" effect because it represents the change in economic activity resulting from the changes in spending by workers whose earnings are affected by the spending on transit.

\section{The sum of the indirect and induced effects represents the multiplier effect of the spending on transit. This is because this sum represents the additional change in the local economy beyond the initial change from the spending on transit.}

Tracing this path for any specific set of spending on transit is extremely costly. Fortunately, multipliers have been made available to reflect the interactions across all industries in a local economy, and these multipliers are updated as the conditions of a local economy changes over time.

These multipliers are derived from detailed accounting tables that show the goods and services produced by each industry and the use of those goods and services by industries and consumers, governments, and investments. Base tables are constructed at the national level, and tables for smaller regions are derived by making adjustments to account for local supply conditions. Local industries often do not supply all of the intermediate inputs needed to produce the region's goods and services; they must purchase some intermediate inputs from suppliers outside the region. These purchases from outside suppliers are typically called "leakages" because they represent money no longer circulating in the local economy. The Regional Input-Output Modeling System (RIMS II) accounts for these leakages by considering each industry's concentration in the region relative to its concentration in the nation.

There are two types of multipliers in terms of what ripple effects are captured-Type I and Type II. Type I multipliers capture only the ripple effects on the business side, and Type II multipliers capture the ripple effects on the household side as well. Type II multipliers should be used to estimate the full economic impacts of spending on transit.

Specifically for each of the four measures of economic activity, Type II multipliers for spending on transit show:

- Output Multiplier - a total change in local output across all industries to a dollar change in spending on transit. 
- Value Added Multiplier - a total change in local value added to a dollar change in spending on transit.

- Earnings Multiplier - a total change in household earnings to a dollar change in spending on transit.

- Jobs Multiplier - a total change in local employment to a million dollar change in spending on transit.

Type II multipliers are made available for individual industries. For estimating the economic impacts of spending on transit operations and maintenance (O\&M), for example, one may use the Type II multipliers derived for the industry of operating transit and ground passenger transportation, which is referred to as the public transit industry below. For estimating the economic impacts of capital spending on building a maintenance facility, as another example, one may use the Type II multipliers derived for the general construction industry.

Once the amount of spending on transit is known for a specific industry and the corresponding Type II multipliers are obtained for this industry, the basic method is ready to estimate the economic impacts of this spending on transit. Consider transit O\&M spending for illustration. In this case, the Type II multipliers for the public transit industry would be used. One way to use the basic method to estimating the impacts of the transit O\&M spending for each of the four measures of economic activity as follows:

- $\quad$ Output $=$ O\&M spending $\times$ Output Multiplier for the public transit industry

- Value Added $=$ O\&M spending $\times$ Value Added Multiplier for the public transit industry

- Earnings $=$ O\&M spending $\times$ Earnings Multiplier for the public transit industry

- Jobs $=$ O\&M spending $\times$ Jobs Multiplier for the public transit industry

\section{Best Practices}

This section covers some of the best practices built into the final tool. The appendix summarizes these as well as other best practices in a single table and discusses simplifying assumptions made in implementing these best practices.

The starting point here is that it is a best practice to consider the pattern of spending on transit when estimating its economic impacts. The pattern of spending on transit characterizes the spending in terms of whether it is spent on locally-produced goods and services, the source of funds, and whether it is borrowed funds, etc. One source of best practices on estimating the economic impacts of spending on transit is Chapter 3 of TCRP Report 78, "Estimating the Benefits and Costs of Public Transit Projects: A Guidebook for Practitioners" (2002). One best practice is that multipliers are applied only to the "net direct expenditures" of a project when estimating the economic impacts of spending on a transit project. The "net direct expenditures" of a transit project represent only the nonlocal funds spent in the study area. 


\section{Destination of Spending}

Consider where the money is spent first. As described earlier about what the basic method tries to do and what the multipliers capture, the money spent on goods and services produced outside the study area in the subsequent rounds by both industries and households is already reflected in the multipliers through accounting for the leakages from the study area to the rest of the world. However, these multipliers do not capture the upfront leakages, i.e., any money spent on goods and services produced outside the study area with the spending on transit. It is true that spending on goods and services produced outside the study area will also generate economic activity, but they are outside the study area. To estimate the economic impacts of the spending on transit on the local economy, these up-front leakages should be excluded before applying the multipliers. TCRP Report 78 suggests that spending on goods and services produced outside the study area be excluded without further consideration.

The current research, however, goes one step further beyond the best practice suggested by TCRP Report 78. Instead of ignoring such outside spending entirely, the current implementation of the basic method tracks the source of funds for the outside spending:

- Outside Funds-If the money comes from outside the study area, it represents a simple flow-through of funds. Such spending on transit has no other impact, positive or negative, on the local economy. In this case, the best practice by TCRP Report 78 works well.

- Local Funds - If the money comes from the study area, the impact of spending the local funds outside the study area would not be simply zero. Imagine what may happen to the money if no spending on transit occurred at all: these local funds would remain in the study area and could support a certain amount of economic activity in the local economy. The exact amount of economic activity supported will depend on how these local funds would be spent in the absence of spending on transit. For simplicity and minimizing input data, the current research assumes that households in the study area will retain control of the money and will spend it on consumer goods and services as they do with their other available funds.

This implementation of the basic method with respect to local funds spent outside the study area is consistent with the best practices suggested by the U.S. Bureau of Economic Analysis. These best practices are in the new User Guide to its RIMS II program, "RIMS II:

An Essential Tool for Regional Developers and Planners," available at http://www.bea.gov/regional/pdf/rims/RIMSII User Guide.pdf on the RIMS II web site. Specifically, one of these best practices calls for accounting the net purchases of goods and services produced in the local economy with and without the new spending being considered:

- The User Guide illustrates this practice by considering the economic impacts of building a new shopping mall in a study area. If a portion of the sales at the new mall would have occurred at any existing shops in the study area, the estimated economic impacts of the new mall should not be based only on the full amount of 
sales at the new mall. Rather, the estimation should be based on the sales at the new mall less lost sales at existing shops within the study area.

- In the present case, the estimation should be based on the net purchases of locallyproduced goods and services between spending the local funds outside the study area for transit purposes and spending the local funds inside the study area by local households for consumer spending. The net purchases of locally-produced goods and services are negative in the case where the local funds are spent outside the study area for transit purposes. As a result, spending local funds outside the study area has a drag effect on the local economy when estimating the economic impacts of such spending for transit purposes.

\section{Source of Funds for Local Spending}

Consider next where the money comes from for any local spending, i.e., spending on goods and sevices produced in the study area:

- Outside Funds-If the money comes entirely from outside the study area in the form of state and/or federal assistance and is not required to be paid back, it would represent the infusion of new money in the study area and, hence, would stimulate the local economy. Therefore, spending outside funds in the study area should positively impact the local economy and must be fully included when applying the multipliers.

- Local Funds-If the money comes from entirely within the study area, on one hand, spending it in the study area on transit projects and services will support a certain level of economic activity in the study area. Is it reasonable to consider the economic activity supported by this portion of the spending on transit as an impact of the spending on transit? To answer, one has to consider the level of economic activity supported by the same money spent differently in the study area. While the mix of industries involved will likely differ between spending the local money on transit vs. spending it alternatively in the study area, the impacts are probably comparable in magnitude. Therefore, spending local funds, even if spent on goods and services produced in the study area, must be fully excluded before applying the multipliers. This is again consistent with the best practices suggested by the RIMS II User Guide for considering only net purchases of locally-produced goods and services.

\section{Borrowed Funds for Local Spending}

Consider whether it makes any difference if any local spending uses borrowed funds from outside the study area that must be paid back in the future. Is it reasonable to consider the economic activity supported by the borrowed spending on transit as a true impact of the spending on transit? To answer, one has to consider the consequences of the repayments in the future: 
- Outside Funds for Repayments-If the debt repayments in the future will be made with outside funds, these payments will not have any negative effect on the local economy. This scenario occurs, for example, if state and federal assistance can be used for these repayments in the future. Consequently, spending borrowed outside funds will positively stimulate the local economy and must be fully included before applying the multipliers.

- Local Funds for Repayments-If the debt repayments in the future will be made with local funds, these payments will negatively affect the local economy during the future years when these repayments are made. To fully account for the negative effects of these debt repayments on the future local economy is difficult, not only because of the temporal dimension but also because the local economy will be different from today. A reasonable approximation would be that the positive effects of the borrowed outside funds on the local economy today are comparable to the negative effects of the debt repayments on the future local economy in today's terms. Therefore, spending from borrowed funds must be excluded before applying the multipliers if they are expected to be paid back in the future with local resources. This implementation of the basic method again is consistent with the best practice suggested by the RIMS II User Guide for the need to consider net purchases of locally-produced goods and services.

\section{Full Employment}

When the local economy reaches full employment, i.e., the condition in the labor market in which there is no excess supply of or demand for labor at prevailing wages, additional spending on transit is not likely to create additional jobs in the local economy at these prevailing wages. The unemployment rate under this condition is referred to as the "natural rate of employment." The best practice in this case is to assume zero job impacts for the spending on transit.

This tool makes this assumption only for transit spending on service expansion or new services and defines full employment as the condition where the unemployment rate reaches 4.8 percent or lower for any study area. The Congressional Budget Office (CBO) provides quarterly estimates of the natural rate for the U.S. as a whole. The estimated natural rate for historical years and the projected natural rate for future years have fluctuated from 4.8 percent to 6.0 percent; as a result, an unemployment rate of 4.8 percent or lower defines full employment for this tool.

\section{Minimum Input Data}

The basic method and best practices discussed above and built into the tool require some basic input data. In addition, the desire for the tool be simple and easy to use imposes some specification on these basic data. The research project took one particular step to minimize the amount of data required for the tool, conditional on satisfying the data needs for the basic method and the best practices. 


\section{Basic Data Requirements}

Using the basic method to estimate the economic impacts of spending on transit means several requirements on input data:

- Type II multipliers for detailed individual industries that are specific to the study area

- Separate data for capital and O\&M spending because they require multipliers for different industries

- Separate data on capital spending for different categories of capital projects because they may require multipliers for different industries

Implementing the best practices in the tool requires some detail on the spending data:

- Pattern of spending and fund source

- Distribution of spending by where the money is spent

- Distribution of spending by where the money comes from

- Distribution of spending by whether the money is borrowed

- Distribution of debt repayments by where the money may come from

- Components of spending data because they may involve different patterns of spending and fund source

- Separate data for capital and O\&M spending

- Separate data on capital spending for different categories of capital projects

\section{Specifications for Simplicity}

To keep the tool simple and easy to use, the research project took several steps in the tool:

- Relies on the National Transit Database (NTD) for spending data-this step reduces the amount of effort needed to compile the required spending data, at least for existing services.

- Pre-specifies categories of capital projects-this step makes it possible to rely on the NTD for spending data for existing services; in addition, this step makes it possible to pre-specify the industries for multipliers.

- Pre-specifies the industry for each component of spending, including total O\&M spending and each pre-specified category of capital projects-this avoids the need for the user to select the proper multipliers.

- Relies on RIMS II multipliers-the tool uses RIMS II of the U.S. Bureau of Economic Analysis as the default for the needed Type II multipliers. At a price of $\$ 275$ (2013) for each study region, RIMS II is a low-cost source for multipliers. The delivery is quick through the RIMS II web page (https://www.bea.gov/regional/rims/rimsii/) after the user is notified via the e-mail address provided with the purchase order. These multipliers come in simple and relatively small tables. This step also makes it easier to pre-specify the industries for needed multipliers. 


\section{Simplifying Assumptions}

To minimize the required input data while satisfying other design features of the tool, the research makes several simplifying assumptions about how certain patterns of spending and fund sources determine the estimated economic impacts of spending on transit being considered:

- Most of these assumptions were discussed earlier about how the tool reflects the best practices of implementing the basic method for impact assessment. These simplifying assumptions all deal with the potential impacts of spending the local funds for non-transit purposes.

- Spending to pay for the cost of land for construction projects has no impacts. One underlying assumption is that any transaction cost for land acquisition is either included in the construction cost or is negligible. Another assumption is that the spending would still be used to pay for the cost of land if transit service were not provided.

- The required data on capital spending for each of the facility-related types do not separate spending for construction from spending for equipment as part of these facilities. The simplifying assumption is that the spending for equipment represents a small share of the total spending for each project types.

\section{Flexibility}

It is not uncommon for different stakeholders to have different questions with regards to the economic impacts of spending on transit. To accommodate these varying questions the tool provided offers various options and measures.

\section{Type of Impacts}

Results are presented separately for each of four measures of economic activity used by the tool for every application:

- Output represents the total gross sales in the economy.

- Value Added is comparable to gross domestic product (GDP) at the local level.

- Earnings represent labor income by workers.

- Jobs represent the number of both full- and part-time jobs in person years.

The first three types of impacts are stated in dollar terms and the last is stated in personyears of both part-time and full-time employment. For all four measures of economic activity, the estimated impacts by this tool for any given set of spending on transit are for all industries affected. Being estimated with RIMS II multipliers, the impacts cannot be meaningfully disaggregated for each of these affected industries. 


\section{Type of Spending}

The tool offers four options in estimating the economic impacts of spending on transit by type of spending:

1. Capital spending only-this option is implicitly chosen when the user enters data only for capital spending.

2. O\&M spending only-this option is implicitly chosen when the user enters data only for O\&M spending.

3. Both capital and O\&M spending combined-when the user enters data for both capital and O\&M spending, the tool provides separate estimates of impacts for the capital spending only, for the O\&M spending only, and for capital and O\&M spending combined. This option is chosen when the user enters data for both spending types but uses only the combined economic impacts of both spending types.

4. Both capital and O\&M spending separately-this option is chosen similarly when the user enters data for both spending types but uses only the separate economic impacts for each spending type.

\section{Nature of Impacts}

The tool offers two options for the nature of the impacts and it measures and provides results for both options for every application. For ease of reference, the estimated impacts are referred to as "net" and "gross." This is a critical distinction, and the user must fully understand it before using and interpreting the results from the tool.

As the built-in best practices call for, the tool is designed primarily to estimate the net impacts of spending on transit in a given study area, which represent the impact on the local economy from spending outside funds inside the study area after accounting for the impact on the local economy from spending any inside funds alternatively for non-transit purposes. After appropriate multipliers are applied to the rows with a "+" or "-" in the "Net" column of Table $2-1$, the sum of that column gives the net impacts of the total spending considered. The net impacts of a given set of spending on transit would disappear entirely if that spending on transit were not made.

To meet the need for some communities to know the amount of economic activity supported by their spending on transit, this tool also provides estimates of the gross impacts of the same spending, which represents the impact on the local economy from spending funds from both outside and local sources without considering the potential impact of spending any local funds alternatively for non-transit purposes. The sum of column "Gross" in Table 2-1 gives the total gross impacts of the total spending considered after appropriate multipliers have been applied to the rows with a "+." The gross impacts of the same spending on transit may not disappear entirely if that spending on transit were not made. 
Table 2-1. Defining Net and Gross Impacts

\begin{tabular}{|l|l|l|c|c|}
\hline Financing & $\begin{array}{l}\text { Debt } \\
\text { Repayment }\end{array}$ & Spending Pattern & Net & Gross \\
\hline \multirow{4}{*}{$\begin{array}{l}\text { Non- } \\
\text { Financed }\end{array}$} & & Outside money spent outside & 0 & 0 \\
\cline { 2 - 5 } & & Outside money spent inside & + & + \\
\cline { 2 - 5 } & & Inside money spent inside & 0 & + \\
\hline \multirow{2}{*}{$\begin{array}{l}\text { Financed } \\
\text { (from } \\
\text { outside) }\end{array}$} & $\begin{array}{l}\text { Outside } \\
\text { money }\end{array}$ & Inside money spent outside & - & 0 \\
\cline { 2 - 5 } & Inside money & Spent outside & 0 & 0 \\
\cline { 2 - 5 } & Spent inside & + & + \\
\cline { 2 - 5 } & Spent inside & - & + \\
\hline
\end{tabular}

Figure 2-1 further illustrates some of these differences between net and gross impacts for a given set of spending on transit that uses some local funds. Spending the $\$ 2$ million from all sources on transit in this example supports a total of 32 jobs (i.e., gross impacts) but creates only a total of 16 jobs (i.e., net impacts) in the local economy.

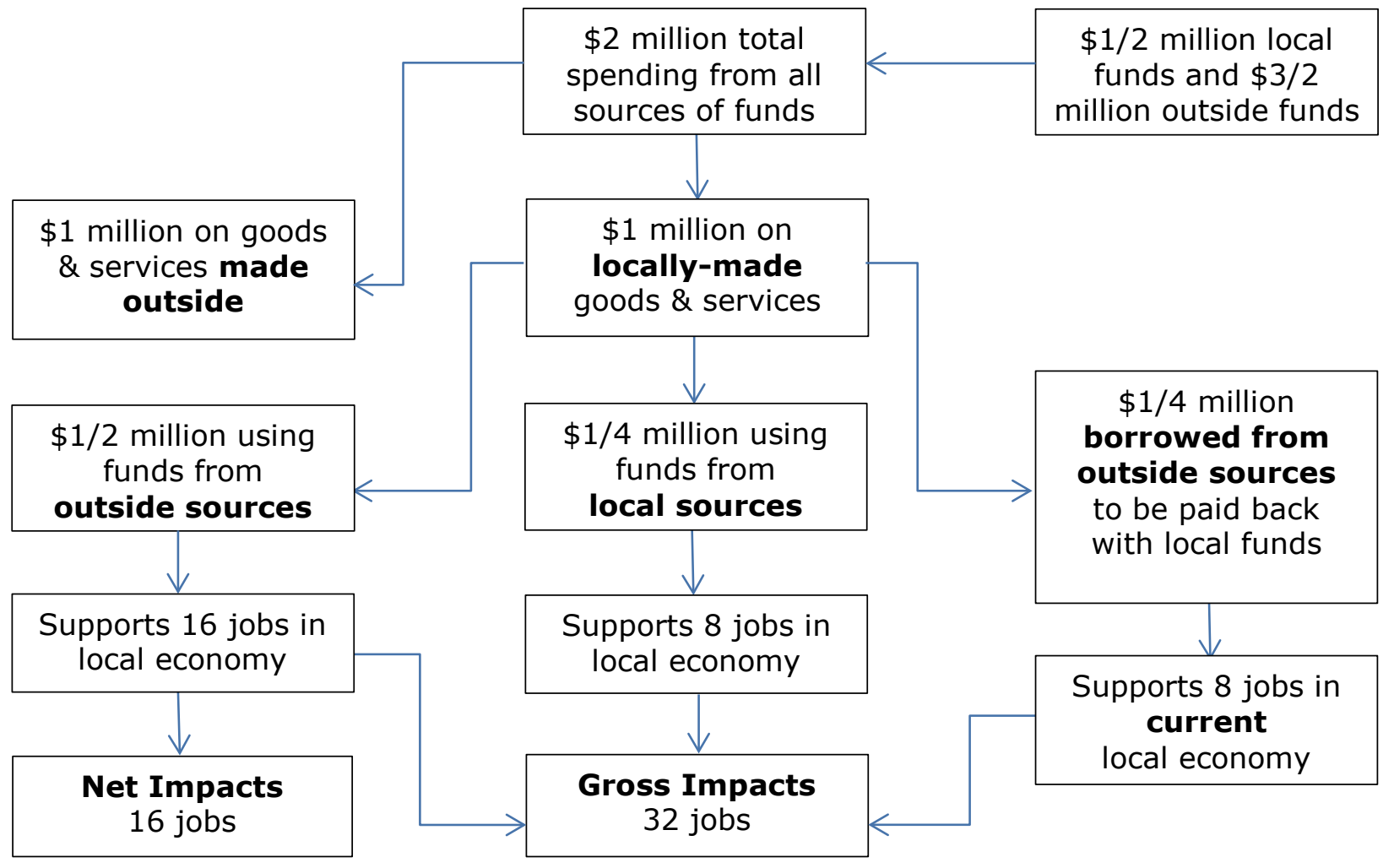

Figure 2-1. Illustration of Differences between Net and Gross Impacts

Total vs. Unit Impacts

The tool presents the estimated economic impacts both in terms of "total impacts" expressed in units such as dollars and jobs and in terms of "unit impacts" calculated as the 
ratio of total impacts over the amount of spending on transit. The total impacts of a given set of spending may be used to indicate the size of the impact of the transit investment on the local economy. In contrast, the unit impacts may be used to indicate the rate-of-return of the same transit investment on the local economy.

Consider just the net impacts in the example of Figure $2-1$, the 16 jobs created represent the total impacts of spending the $\$ 2$ million from all sources. The corresponding unit impacts are 8 jobs created per $\$ 1$ million of spending funds from all sources.

\section{Leveraging Effects}

The tool also presents the results on unit impacts in two alternative measures. One is given by the ratio of the total impacts of a given set of spending on transit over the total spending. This is the default measure of unit impacts and may be referred to as the "regular unit impacts" for ease of reference. The other measure is given by the ratio of the same total impacts over only the portion of the total spending using local resources. Local resources include government, agency-generated, and transit-dedicated revenues. For ease of reference, this alternative measure may be referred to as the "leveraged unit impacts." The measure of leveraged unit impacts captures not only the impacts of spending the local resources but also the leveraging effect of spending the local resources in bringing state and federal resources. In a formula format, these two measures are:

$$
\begin{gathered}
\text { Regular Unit Impacts }=\frac{\text { Total Impacts }}{\text { Total Spending on Transit Using Local and Outside Funds }} \\
\text { Leveraged Unit Impacts }=\frac{\text { Total Impacts }}{\text { Spending on Transit Using Local Funds Only }}
\end{gathered}
$$

For a given set of transit spending considered, the measure of leveraged unit impacts will necessarily be the same or larger than the measure of regular unit impacts, reflecting the leveraging effect of spending local resources by crediting all the impacts to the local resources. Continue with the net impacts in the example of Figure 2-1. The regular unit impacts are 8 jobs created per $\$ 1$ million of spending funds from all sources. The measure of regular unit impacts in this case is calculated as the ratio of the total impacts of 16 jobs created over the total spending of $\$ 2$ million. The leveraged unit impacts, on the other hand, are 32 jobs created per $\$ 1$ million spending of local funds. The measure of leveraged unit impacts in this case is calculated as the ratio of the total impacts of 16 jobs created over the $\$ 1 / 2$ million local funds used for the total spending.

\section{Applicability}

The tool is applicable to any given set of spending on transit as long as the required data are available either from observation or estimation and the application is proper relative to the limitations of RIMS II multipliers. Therefore this tool does not preclude it from being applied to any specific type of spending on transit, including: 
- Any mode of transit: commuter rail, light rail, bus rapid transit, paratransit, etc.

- Any nature of service: existing service, expansion of service, or planned new service

- Any type of spending: capital or O\&M

As noted previously, however, the tool does not calculate the transportation benefits of transit investments nor is it designed to evaluate the economic impacts of alternative uses to transit funds-for example, spending on roadway projects.

\section{Feasible Applications}

The tool is applicable only if the study area consists of a single county or more than one spatially-contiguous county, i.e., two or more neighboring counties, one Census-designated metropolitan statistical area, etc.

Given a county-based study area, the tool is designed to estimate the economic impacts of spending on transit primarily for cases of existing services where all required data are readily available and specific to the study area.

Beyond these cases of the tool's primary applicability, the tool may still be used for estimating the economic impacts of spending on transit in additional contexts where various assumptions are required to assemble the necessary data:

- Necessary multiplier data are readily available and specific to the study area, but data on the patterns of spending and fund source are estimated for existing services.

- Data on spending and patterns of spending and fund source are readily available and specific to the study area, but multipliers are not available for existing services:

- Use RIMS II multipliers already purchased for the same study area for assessing the economic impacts of spending on non-transit projects

- Derive Type II multipliers for the pre-specified industries for the same study area from a non-RIMS II source, such as IMPLAN

- Data on RIMS II multipliers are available and specific to the study area for base existing services; reasonable estimates of data on spending and patterns of spending and fund source are available for service expansion in the same study area. The following are examples of such service expansion:

- More service on existing routes-use the available multipliers

- New routes of the same mode-use the available multipliers

- New service for a mode significantly different from the base mode of service - Use the RIMS II multipliers for the existing base mode of service with caution

- Alternatively, borrow RIMS II multipliers for the same new mode of service from a peer study area with extreme caution

- Reasonable estimates of spending data and patterns are available, but multipliers are not available. The user may borrow multipliers from peer study areas with extreme caution: 
- Planned transit service for a study area with no existing transit service (new service area)

- Relatively new existing service that has not yet been captured by the latest RIMS II multipliers

\section{Proper Applications}

For any case for which applying the tool is physically feasible, the user still should consider whether a potential application is within the limitations of RIMS II multipliers. These issues are discussed in two guidance documents for RIMS II multipliers by RIMS II staff. One is the new User Guide already mentioned earlier. The other is "Input-Output Models for Impact Analysis: Suggestions for Practitioners Using RIMS II Multipliers," available at http://www.bea.gov/papers/pdf/WP IOMIA RIMSII 020612.pdf on the RIMS II website.

- Study Area-Besides being one or more spatially-contiguous counties, the chosen study area should be one in which workers live and spend most of their earnings.

- It would not be appropriate to apply this tool to an entire state, for example, when the transit service is provided only in a single region of the state; applications to study areas that are too large lead to inflated impacts.

- At the same time, it would not be appropriate to apply this tool to a study area that is too small relative to an area in which workers live and spend most of their earnings; applications to study areas that are too small not only require extra effort for attributing aggregated spending data to the small study area but also lead to understating the true impacts. For estimating the economic impacts of LYNX's spending on transit, for example, the most appropriate study area was the Census-designated statistical metropolitan area Orlando-Kissimmee-Sanford, which consists of the counties of Lake, Orange, Osceola, and Seminole.

- Size of Spending-The spending on transit being considered should not be too large to affect the structure of the local economy. When the structure of the local economy is altered, existing multipliers derived on the basis of the current structure should not be used. For estimating the economic impacts of the entire public transit industry in a study area, for example, the application should be limited to study areas where the transit industry does not represent a significant presence in the local economy.

- Non-Specialized Labor-The tool should be limited to capital projects that do not require a significant number of specialized workers. RIMS II assumes that local workers can work on all types of construction projects. The construction of some capital projects uses specialized workforces from outside the study area-for example, ironworkers may be brought in to help build rail tracks. The construction multipliers may produce inflated impact estimates for projects that use unusually high levels of specialized, non-local labor.

- Nature of Employment-RIMS II employment multipliers are not stated in full-time equivalent (FTE) employment. As a result, the estimated job impacts partly depend on the mix of part-time and full-time workers in individual industries. The tool may be used for cases where the job impacts need not be stated in FTE employment. In 
addition, RIMS II employment multipliers cannot be meaningfully disaggregated by industry. As a result, the estimated job impacts from this tool are for all industries affected by the spending on transit considered. The tool may be used for cases where the job impacts need not be specific to individual industries.

- Persistency of Spending-The spending on transit being considered should be permanent or at least persistent enough to allow for the "shock" to fully work through the economy. If the initial impact is not persistent, as may be the case with a small and brief construction project, then firms in the local area may increase output without hiring as many additional employees or buying as many additional inputs from the local economy as the multipliers assume. In these cases, the actual impact of the change on the local economy will be smaller than that estimated in an impact study.

- Permanency of Impacts-The tool is annual-based, using annual spending data and producing annual economic impacts. In addition, the economic impacts of capital spending for a one-time capital project are considered to be short-term, but the economic impacts of O\&M spending are considered to be long-term as long as O\&M spending continues over time. Even for capital spending, however, the estimated economic impacts can also be long-term if the capital spending is annually based and continue over time, although the exact level may fluctuate to some degree.

To sustain a given number of jobs created from spending on transit over time requires that a similar amount of spending on transit is sustained and a similar pattern of the spending, including fund sources, spending destinations, and whether funds are borrowed, to continue over time. Even if the amount of spending on transit is sustained over time, changes to the pattern of the spending can lead to significantly different economic impacts.

\section{Sensitivity Analysis}

The economic impacts estimated from this tool can contain some degree of uncertainty from various sources. The user has no control over some of these sources, including:

- $\quad$ Simplifying assumptions made

- Robustness of the multipliers supplied (which may be affected by the size of the local economy and its stability during the multiplier development time period)

The user has some control over many other sources of uncertainty, including:

- Accuracy of actual spending for existing services when estimated

- Accuracy of estimated distributions for actual spending

- Accuracy of estimated spending and patterns for planned spending

- Accuracy of borrowed multipliers 
When the tool is determined to be applicable, a sensitivity analysis is highly recommended with respect to estimated spending data or borrowed multipliers. The tool, as designed, can be used for such a sensitivity analysis with multiple applications of the tool. This would take the following steps:

1. Identify the input data with relatively low confidence.

2. Set up alternative values of these input data.

3. Apply the tool to the base values of the input data.

4. Apply the tool to the alternative values of these input data.

5. Compare the results between using the base values and the alternative values.

6. Draw conclusions for decision-makers. 


\section{Chapter 3 - Excel-Based Tool}

This chapter first describes the tabs of the Excel-based template. It then provides guidance for obtaining the required input data, including multipliers and spending data. This chapter is written in the style of a user's manual. Data related to LYNX in Central Florida are used as examples.

\section{Components}

This tool contains four tabs-COVER, INPUT, CALCULATIONS, and RESULTS. The COVER, INPUT, and RESULTS tabs will be visible, but the CALCULATIONS tab is hidden to avoid confusion.

COVER - This tab introduces the tool, summarizes its main features, and includes a PDF version of this report inserted into the worksheet serving as the user guide.

INPUT - This tab is where the required input data are entered for estimating the economic impact of spending on public transit. The required input data fall into six groups:

1. Nature of spending on transit - specifies whether the spending on transit is for existing services or for service expansion (including new service).

2. Unemployment rate - required only if the economic impacts of spending on transit for service expansion or new service are considered; represents the current unemployment rate in the study area.

3. RIMS II multipliers - enter the multipliers for each of six detailed industries and for two aggregated industries. These are the Type II final-demand multipliers for output, earnings, jobs, and value added. Figure 3-1 shows how this section appears in INPUT.

1. Enter Type II final-demand multipliers from Table 1.5 on the right for each industry shown on the left:

\begin{tabular}{|l|c|c|c|c|c|}
\hline \multicolumn{2}{|c|}{ RIMS II Detailed Industry } & \multicolumn{3}{c|}{ Type II Final-Demand Multipliers } \\
\hline Industry Name & $\begin{array}{c}\text { Industry } \\
\text { Code }\end{array}$ & 0utput & Earnings & Jobs & $\begin{array}{c}\text { Value } \\
\text { Added }\end{array}$ \\
\hline Construction & 230000 & 1.7798 & 0.3953 & 10.5463 & 0.9664 \\
\hline Automobile manufacturing & 336111 & 1.0000 & 0.0000 & 0.0000 & 0.0000 \\
\hline Heawy duty truck manufactoring & 336120 & 1.0000 & 0.0000 & 0.0000 & 0.0000 \\
\hline Railroad rolling stock manufactoring & 336500 & 1.0000 & 0.0000 & 0.0000 & 0.0000 \\
\hline Transit and Ground Passenger Transportation & $485 \mathrm{A00}$ & 1.8658 & 0.4079 & 15.1392 & 0.8494 \\
\hline Households & $\mathrm{H00000}$ & 1.0816 & 0.2165 & 6.6058 & 0.6727 \\
\hline
\end{tabular}

2. Enter Type II final-demand multipliers from Table 2.5 on the right for each industry shown on the left:

\begin{tabular}{|l|c|c|c|c|c|}
\hline \multicolumn{2}{|c|}{ RIMS II Industry Aggregation } & \multicolumn{4}{c|}{ Total Multipliers } \\
\hline Industry Name & $\begin{array}{c}\text { Industry } \\
\text { Code }\end{array}$ & Output & Earnings & Jobs & $\begin{array}{c}\text { Value } \\
\text { Added }\end{array}$ \\
\hline Computer and electronic product manufactoring & 13 & 1.8420 & 0.3185 & 6.2474 & 0.8590 \\
\hline Professional, scientific, and technical services & 48 & 1.8165 & 0.4923 & 11.6255 & 1.1791 \\
\hline
\end{tabular}

Figure 3-1. RIMS II Multipliers for INPUT 
4. Spending from non-financed sources - for each category of spending, enter the following:

- the amount of spending that originated from sources other than bonds or loans.

- the percent share of this spending outside the study area. Spending outside the study area refers to spending on goods and services that were produced outside the study area. If a bus was purchased from a dealer inside the study area but was manufactured outside the study area, the total spending would be considered as being outside the study area. A portion of the total spending may have been paid to the local dealer but is likely to be a negligible amount relative to the total spending.

- the percent share of this spending that originated from funds outside the study area.

These data are required for total O\&M spending and for total capital spending for each of 12 categories of capital projects. Figure 3-2 shows these categories and how this section appears in INPUT.

1. Spending for capital categories 03 - 07 should exclude cost for land and for design and engineering services when possible.

2. For any of the 03 - 07 capital categories, do not add its cost for land in category 01 if the land cost is not excluded from this category.

3. For any of the $03-07$ capital categories, do not add its design and engineering cost in category 02 if this cost is not excluded from this category.

\begin{tabular}{|c|c|c|c|c|c|c|}
\hline \multirow{2}{*}{$\begin{array}{l}\text { Type of } \\
\text { Spending }\end{array}$} & \multirow{2}{*}{ Category of Spending } & \multirow{2}{*}{$\begin{array}{l}\text { Amount of } \\
\text { Spending }\end{array}$} & \multicolumn{2}{|c|}{$\begin{array}{c}\% \text { Distribution by } \\
\text { Destination of Spending }\end{array}$} & \multicolumn{2}{|c|}{$\begin{array}{c}\% \text { Distribution by Source } \\
\text { of Funds }\end{array}$} \\
\hline & & & \begin{tabular}{|c|} 
Outside \\
Study Area
\end{tabular} & $\begin{array}{c}\text { Inside } \\
\text { Study Area }\end{array}$ & $\begin{array}{l}\text { Outside } \\
\text { Study Area }\end{array}$ & $\begin{array}{c}\text { Inside } \\
\text { Study Area }\end{array}$ \\
\hline O\&M & Total & $\$ 69,568,197$ & $10 \%$ & $90 \%$ & $32 \%$ & $68 \%$ \\
\hline \multirow{12}{*}{ Capital } & 01. Land Cost & $\$ 0$ & $0 \%$ & $100 \%$ & $95 \%$ & $5 \%$ \\
\hline & 02. Design and Engineering & $\$ 0$ & $50 \%$ & $50 \%$ & $50 \%$ & $50 \%$ \\
\hline & 03. Guideway & $\$ 0$ & $75 \%$ & $25 \%$ & $95 \%$ & $5 \%$ \\
\hline & 04. Passenger Stations & $\$ 32,386$ & $0 \%$ & $100 \%$ & $95 \%$ & $5 \%$ \\
\hline & 05. Administrative Buildings & $\$ 339,745$ & $0 \%$ & $100 \%$ & $95 \%$ & $5 \%$ \\
\hline & 06. Maintenance Facilities & $\$ 1,312,588$ & $25 \%$ & $75 \%$ & $95 \%$ & $5 \%$ \\
\hline & 07. Other Capital Projects & $\$ 3,274,438$ & $0 \%$ & $100 \%$ & $95 \%$ & $5 \%$ \\
\hline & 08. Revenue Vehicles - Bus & $\$ 8,270,411$ & $100 \%$ & $0 \%$ & $95 \%$ & $5 \%$ \\
\hline & 09. Revenue Vehicles - Rail & \$o & $100 \%$ & $0 \%$ & $95 \%$ & $5 \%$ \\
\hline & 10. Service Vehicles & $\$ 36,583$ & $100 \%$ & $0 \%$ & $95 \%$ & $5 \%$ \\
\hline & 11. Fair Revenue Collection Systems & $\$ 6,488$ & $100 \%$ & $0 \%$ & $95 \%$ & $5 \%$ \\
\hline & 12. Communications and Information Systems & $\$ 1,269,204$ & $100 \%$ & $0 \%$ & $95 \%$ & $5 \%$ \\
\hline
\end{tabular}

\section{Figure 3-2. Spending from Non-Financed Sources for INPUT}

5. Spending from financed sources - enter the amount of spending that originated from borrowed funds through bonds and loans and the share of this spending made outside the study area. Enter these data for total O\&M and for each category of capital projects. The share for a spending category is required only when this spending is not zero. Figure 3-3 shows how this section appears in INPUT. 
1. Spending for capital project categories 03-07 should exclude cost for land and design and engineering services when possible.

2. For any of the 03 - 07 capital categories, do not add its cost for land in category 01 if the land cost is not excluded from this category

3. For any of the $03-07$ capital categories, do not add its design and engineering cost in category 02 if this cost is not excluded from this category.

\begin{tabular}{|c|c|c|c|c|}
\hline \multirow{2}{*}{$\begin{array}{l}\text { Type of } \\
\text { Spending }\end{array}$} & \multirow{2}{*}{ Category of Spending } & \multirow{2}{*}{$\begin{array}{l}\text { Amount of } \\
\text { Spending }\end{array}$} & \multicolumn{2}{|c|}{$\begin{array}{c}\% \text { Distribution by } \\
\text { Destination of Spending }\end{array}$} \\
\hline & & & \begin{tabular}{c|} 
Outside \\
Study Area
\end{tabular} & $\begin{array}{c}\text { Inside Study } \\
\text { Area }\end{array}$ \\
\hline O\&M & Total & \$o & $10 \%$ & $90 \%$ \\
\hline \multirow{12}{*}{ Capital } & 01. Land Cost & \$0 & $0 \%$ & $100 \%$ \\
\hline & 02. Design and Engineering & \$o & $50 \%$ & $50 \%$ \\
\hline & 03. Guideway & $\$ 0$ & $25 \%$ & $75 \%$ \\
\hline & 04. Passenger Stations & \$0 & $0 \%$ & $100 \%$ \\
\hline & 05. Administrative Buildings & $\$ 0$ & $0 \%$ & $100 \%$ \\
\hline & 06. Maintenance Facilities & $\$ 0$ & $25 \%$ & $75 \%$ \\
\hline & 07. Other Capital Projects & $\$ 0$ & $0 \%$ & $100 \%$ \\
\hline & 08. Revenue Vehicles - Bus & $\$ 0$ & $100 \%$ & $0 \%$ \\
\hline & 09. Revenue Vehicles - Rail & $\$ 0$ & $100 \%$ & $0 \%$ \\
\hline & 10. Service Vehicles & $\$ 0$ & $100 \%$ & $0 \%$ \\
\hline & 11. Fair Revenue Collection Systems & $\$ 0$ & $100 \%$ & $0 \%$ \\
\hline & 12. Communications and Information Systems & \$0 & $100 \%$ & $0 \%$ \\
\hline
\end{tabular}

Figure 3-3. Spending from Financed Sources for INPUT

6. Source of funds used for debt repayments - the input data for this group are required only if any spending originated from borrowed funds through bonds and loans have been entered. The data are required separately for borrowed funds for O\&M spending or for capital spending. Figure 3-4 shows how this section appears in INPUT.

If you have entered data on financed spending above for operating \& maintenance (or capital projects), enter the $\%$ share of debt payments for operating \& maintenance (or capital projects) using funds from outside the study area

\begin{tabular}{|l|r|r|}
\hline \multirow{2}{*}{$\begin{array}{l}\text { Spending purpose of current borrowed funds for which debt payments will be } \\
\text { made in the future }\end{array}$} & $\begin{array}{c}\% \text { Distribution of Payments } \\
\text { by Source of Funds }\end{array}$ \\
\cline { 2 - 3 } & $\begin{array}{r}\text { Outside the } \\
\text { Study Area }\end{array}$ & $\begin{array}{c}\text { Inside the } \\
\text { Study Area }\end{array}$ \\
\hline Operating \& Maintenance & $34 \%$ & $66 \%$ \\
\hline Capital Projects & $75 \%$ & $25 \%$ \\
\hline
\end{tabular}

Figure 3-4. Source of Funds Used for Debt Payments for INPUT

CALCULATIONS - This tab takes all of the input data that are provided in INPUT, accounts for the basic method and best practices described in Chapter 2, and calculates detailed total impacts by source of funds and destination of spending.

RESULTS - This tab presents four sets of summaries:

1. Total Impacts - summarizes the detailed total impacts by source of funds and destination of spending from the CALCULATIONS tab. This summary is done by type of spending (O\&M, capital, and total spending), by type of impacts (output, value added, earnings, and jobs), and by nature of impacts (net and gross). The estimated impacts from this tool are for all industries affected by spending on transit. 
Figure 3-5 shows how these summaries appear in the RESULTS tab along with basic interpretations of these results.

\section{TOTAL IMPACTS}

A. Total Net Impacts

\begin{tabular}{|l|r|r|r|r|}
\hline \multirow{2}{*}{ Type of Spending } & \multicolumn{4}{|c|}{ Type of Impacts } \\
\cline { 2 - 5 } & $\begin{array}{c}\text { Output } \\
\text { (millions) }\end{array}$ & $\begin{array}{c}\text { Value } \\
\text { Added } \\
\text { (millions) }\end{array}$ & $\begin{array}{c}\text { Earnings } \\
\text { (millions) }\end{array}$ & $\begin{array}{c}\text { Jobs } \\
\text { (person- } \\
\text { years) }\end{array}$ \\
\hline Operating \& Maintenance & $\$ 32.51$ & $\$ 13.95$ & $\$ 7.20$ & 274 \\
\hline Capital Projects & $\$ 7.77$ & $\$ 4.21$ & $\$ 1.73$ & 46 \\
\hline Total Spending & $\$ 40.28$ & $\$ 18.16$ & $\$ 8.93$ & 320 \\
\hline
\end{tabular}

Note:

1. These are the estimated true impacts generated by the transit spending considered.

They result from the positive effect of spending outside funds inside the study area, and from

the negative effect of spending inside funds outside of the study area. These net impacts

would not exist without the public transit service. These results also answer this question:

What is the economic impact of removing the transit service?

\section{B. Total Gross Impacts}

\begin{tabular}{|l|r|r|r|r|}
\hline \multirow{2}{*}{ Type of Spending } & \multicolumn{4}{|c|}{ Type of Impacts } \\
\cline { 2 - 5 } & $\begin{array}{c}\text { Output } \\
\text { (millions) }\end{array}$ & $\begin{array}{c}\text { Value } \\
\text { Added } \\
\text { (millions) }\end{array}$ & $\begin{array}{c}\text { Earnings } \\
\text { (millions) }\end{array}$ & $\begin{array}{c}\text { Jobs } \\
\text { (person- } \\
\text { years) }\end{array}$ \\
\hline Operating \& Maintenance & $\$ 116.82$ & $\$ 53.18$ & $\$ 25.54$ & 948 \\
\hline Capital Projects & $\$ 8.24$ & $\$ 4.48$ & $\$ 1.83$ & 49 \\
\hline Total Spending & $\$ 125.06$ & $\$ 57.66$ & $\$ 27.37$ & 997 \\
\hline
\end{tabular}

Note:

1. These are the estimated economic activities supported by all of the considered transit spending inside the study area without considering the source of funds. They include not only the net impacts from above, but also the economic activities supported by the inside funds spent inside the study area. These results also answer this question: What is the amount of economic activity that this transit service supports?

\section{Figure 3-5. Summary of Total Impacts in RESULTS}

2. Total Spending - for a better understanding of the spending data entered, this tab also summarizes the spending data by both source of funds and destination of spending for O\&M, capital, and total spending, respectively (Figure 3-6). This summary also aids in understanding the portions of the spending that really matter in the estimated total impacts. 


\section{Total Spending (millions)}

\begin{tabular}{|l|r|r|r|r|}
\hline Source of Funds & \multicolumn{2}{|c|}{ Outside Study Area } & \multicolumn{2}{|c|}{ Inside Study Area } \\
\hline Destination of Spending & $\begin{array}{c}\text { Inside } \\
\text { Study } \\
\text { Area }\end{array}$ & $\begin{array}{c}\text { Outside } \\
\text { Study } \\
\text { Area }\end{array}$ & $\begin{array}{c}\text { Inside } \\
\text { Study } \\
\text { Area }\end{array}$ & $\begin{array}{c}\text { Outside } \\
\text { Study } \\
\text { Area }\end{array}$ \\
\hline Operating \& Maintenance & $\$ 20.16$ & $\$ 2.24$ & $\$ 42.45$ & $\$ 4.72$ \\
\hline Capital Projects & $\$ 4.41$ & $\$ 9.44$ & $\$ 0.22$ & $\$ 0.08$ \\
\hline Total Spending & $\$ 24.57$ & $\$ 11.68$ & $\$ 42.67$ & $\$ 4.79$ \\
\hline
\end{tabular}

Notes: These are summarized from the spending data you have entered in INPUT. Inside funds include revenues directly generated by the transit agency, general government revenues, and tax revenues designated for the transit service. State resources (general revenues or tax revenues designated for the transit service) would be inside funds if the study area is a state. Outside funds include Federal resources and state resources if the study area is part of a state.

\section{Figure 3-6. Summary of Spending in RESULTS}

3. Unit Impacts for Spending of Funds from All Sources - the results for unit impacts indicate the relative size of the impacts, i.e., relative to the amount of spending involved. The results for unit impacts may be used to indicate the rateof-return for investments in public transit. This is one of two measures of unit impacts and is measured relative to

The results for unit impacts may be used to indicate the rate-of-return for investments in public transit. spending of funds from all sources. With this measure of unit impacts, the numerator (total impacts) and the denominator (spending) are consistent in that the total impacts in the numerator resulting from the amount of spending in the denominator. Results are provided for both unit net impacts and unit gross impacts and for each spending type (O\&M, capital, and total). Figure 3-7 shows how these results appear in RESULTS. 


\section{UNIT IMPACTS}

A. Unit Impacts for Spending of Funds from All Sources

1. Unit Net impacts

\begin{tabular}{|l|r|r|r|r|}
\hline \multirow{2}{*}{ Type of Spending } & \multicolumn{4}{|c|}{ Type of Impacts } \\
\cline { 2 - 5 } & Output & $\begin{array}{c}\text { Value } \\
\text { Added }\end{array}$ & Earnings & \multicolumn{1}{|c|}{ Jobs } \\
\cline { 2 - 5 } & \multicolumn{3}{|c|}{ For every $\$ 1$ invested } & $\begin{array}{c}\text { For every } \$ 1 \\
\text { million invested }\end{array}$ \\
\hline Operating \& Maintenance & $\$ 0.47$ & $\$ 0.20$ & $\$ 0.10$ & 3.9 \\
\hline Capital & $\$ 0.53$ & $\$ 0.29$ & $\$ 0.12$ & 3.2 \\
\hline Total Spending & $\$ 0.48$ & $\$ 0.22$ & $\$ 0.11$ & 3.8 \\
\hline
\end{tabular}

Notes:

1. The Jobs result helps answer this question: For every $\$ 1$ million invested in capital or operating and maintenance, what is the number of jobs created? The other results help answer this quesiton: For every $\$ 1$ invested in capital or operating and maintenance, what is the dollar amount of output, value added, or household earnings generated?

2. For a given type of spending, the unit net impacts are derived through dividing the total net impacts for this type of spending by the total spending of the same type.

2. Unit Gross Impacts

\begin{tabular}{|l|r|r|r|r|}
\hline \multirow{2}{*}{ Type of Spending } & \multicolumn{4}{|c|}{ Type of Impacts } \\
\cline { 2 - 5 } & Output & $\begin{array}{c}\text { Value } \\
\text { Added }\end{array}$ & Earnings & \multicolumn{1}{|c|}{ Jobs } \\
\cline { 2 - 5 } & \multicolumn{3}{|c|}{ For every $\$ 1$ invested } & $\begin{array}{c}\text { For every } \$ 1 \\
\text { million invested }\end{array}$ \\
\hline Operating \& Maintenance & $\$ 1.68$ & $\$ 0.76$ & $\$ 0.37$ & 13.6 \\
\hline Capital & $\$ 0.57$ & $\$ 0.31$ & $\$ 0.13$ & 3.4 \\
\hline Total Spending & $\$ 1.49$ & $\$ 0.69$ & $\$ 0.33$ & \\
\hline $\begin{array}{l}\text { Notes: } \\
\text { 1. The Jobs result helps answer this question: For every } \$ 1 \text { million invested in capital (or operating } \\
\text { and maintenance), what is the number of jobs supported ? The other results help answer this } \\
\text { quesiton: For every } \$ 1 \text { invested in capital (or operating and maintenance), what is the dollar } \\
\text { amount of output, value added, or household earnings supported? }\end{array}$ \\
$\begin{array}{l}\text { 2. For a given type of spending, the unit gross impacts are derived through dividing the total gross } \\
\text { impacts for this type of spending by the total spending of the same type. }\end{array}$ \\
\hline
\end{tabular}

\section{Figure 3-7. Summary of Unit Impacts for Spending of All Sources in RESULTS}

4. Unit Impacts for Total Spending of Funds from Inside the Study Area - the measure of unit impacts is measured relative to spending of funds from inside the study area (spending of local resources). Local resources include government, agencygenerated, and transit-dedicated revenues. With this measure of unit impacts, the total impacts in the numerator result from the amount of spending from all sources, but the amount of spending in the denominator includes only the portion from local resources. The objective of this measure of unit impacts is to capture not only the impacts of spending the local resources but also the leveraging effect of spending the local resources in bringing state and federal resources. Results are provided for both unit net impacts and unit gross impacts. These results are measured for total spending. Separate results for O\&M spending and capital spending are not measured. Figure 3-8 shows how these results appear in RESULTS. 
B. Unit Impacts for Total Spending of Inside Funds

\begin{tabular}{|l|r|r|r|r|}
\hline \multirow{2}{*}{ Measurement Approach } & \multicolumn{3}{|c|}{ Type of Impacts } \\
\cline { 2 - 5 } & Output & $\begin{array}{c}\text { Value } \\
\text { Added }\end{array}$ & Earnings & Jobs \\
\cline { 2 - 5 } & For every $\$ 1$ of inside funds & $\begin{array}{c}\text { For every } \$ 1 \\
\text { million of inside } \\
\text { funds invested }\end{array}$ \\
\hline Net Impact & $\$ 0.84$ & $\$ 0.38$ & $\$ 0.19$ & 6.7 \\
\hline Gross Impact & $\$ 2.61$ & $\$ 1.20$ & $\$ 0.57$ & 20.8 \\
\hline $\begin{array}{l}\text { Notes: } \\
\text { 1. The Jobs result helps answer this question: For every } \$ 1 \text { million of local resources invested in } \\
\text { capital and operating and maintenance, what is the number of jobs created (Net) or supported } \\
\text { (Gross)? The other results help answer this quesiton: For every } \$ 1 \text { of local resources invested in } \\
\text { capital and operating and maintenance, what is the dollar amount of output, value added, or } \\
\text { household earnings generated (Net) or supported (Gross)? }\end{array}$ \\
\hline
\end{tabular}

Figure 3-8. Summary of Unit Impacts for Spending of Inside Funds in RESULTS

Figure 3-9 summarizes the different measures of impacts available from this tool. Part $A$ is for total impacts and Part $B$ is for unit impacts.

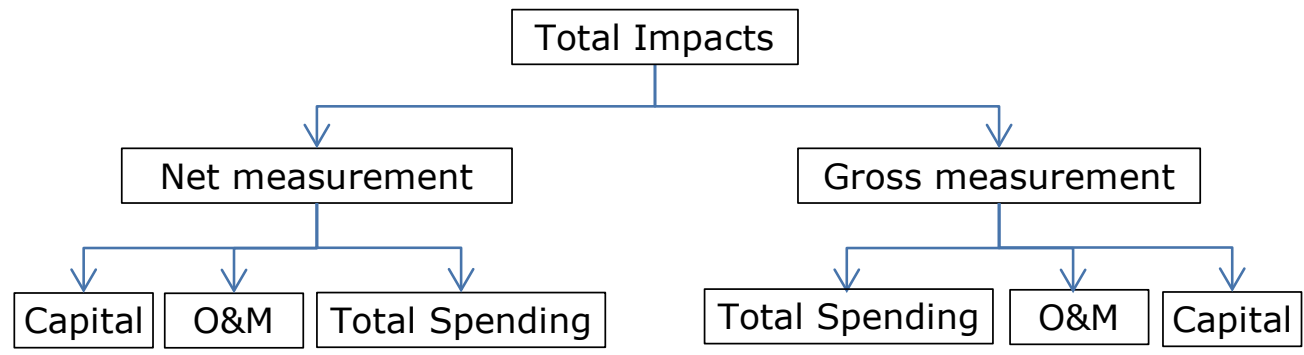

A. Available Measures of Total Impacts

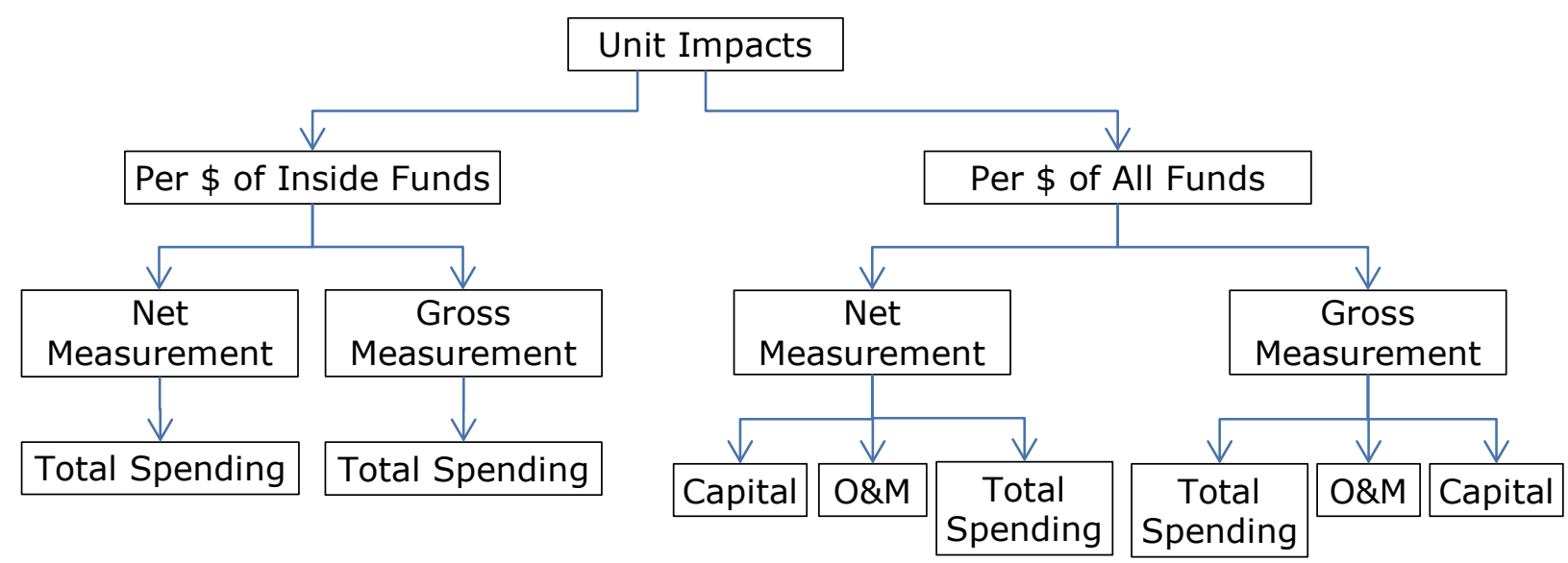

B. Available Measures of Unit Impacts

Figure 3-9. Options of Impact Measures Available 


\section{Obtaining Multipliers}

If not already purchased for another purpose of the same study area, the multipliers must be purchased on a user-by-user basis from the U.S. Bureau of Economic Analysis through its RIMS II Online Order and Delivery System at https://www.bea.gov/regional/rims/rimsii/. This sub-section provides detailed guidance for obtaining data for the multipliers.

\section{Placing an Order}

Shown in Figure 3-10, the first page of the Online Order and Delivery System briefly describes the options (region vs. industry and annual vs. benchmark) and shows the cost of multipliers per region and per industry. Multipliers from the Benchmark Series for regions will be needed.

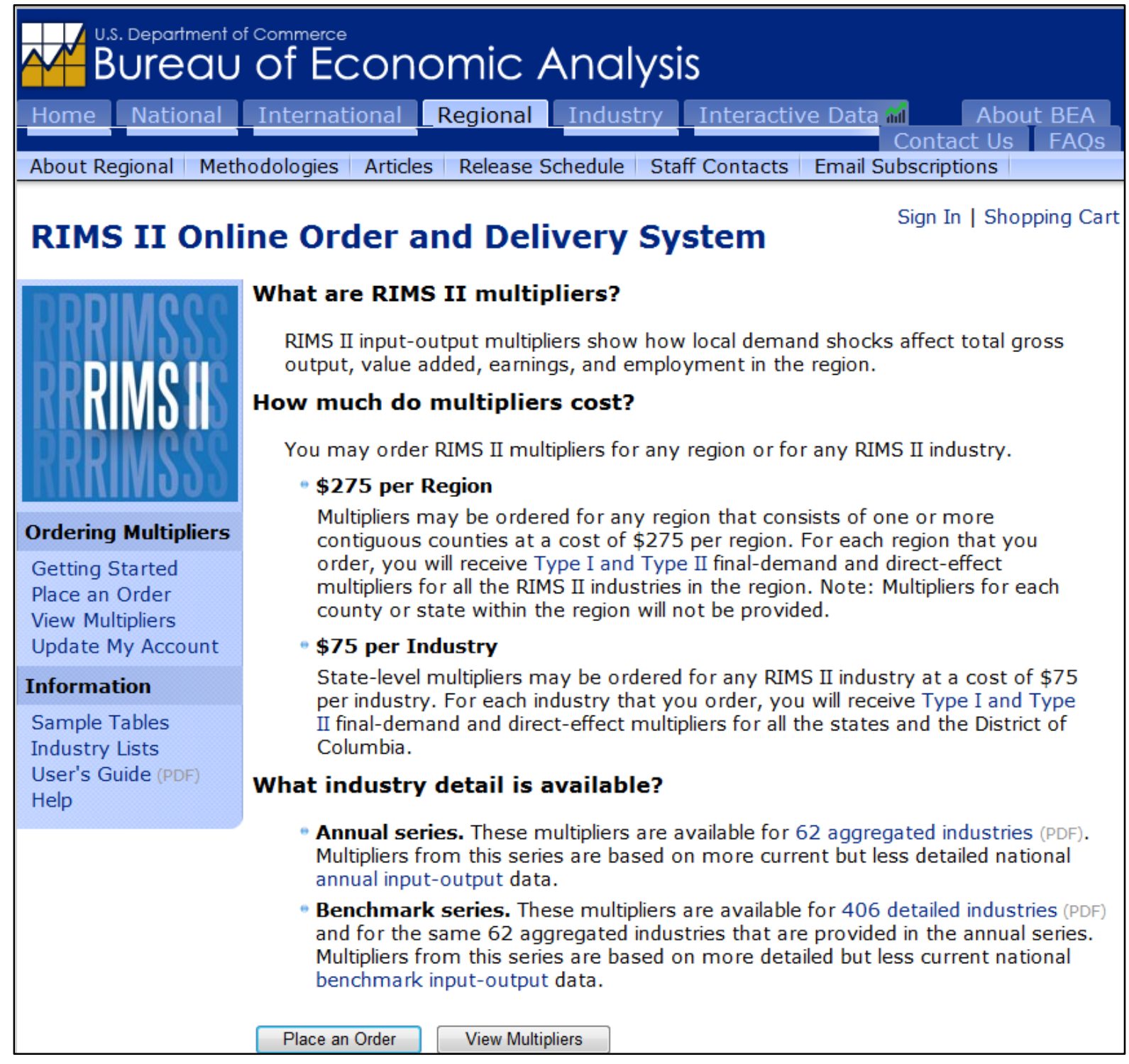

Figure 3-10. Order Options for RIMS II Multipliers 
First, choose these options on the next page (Figure 3-11) after clicking the "Place an Order" button at the bottom of the previous screen.

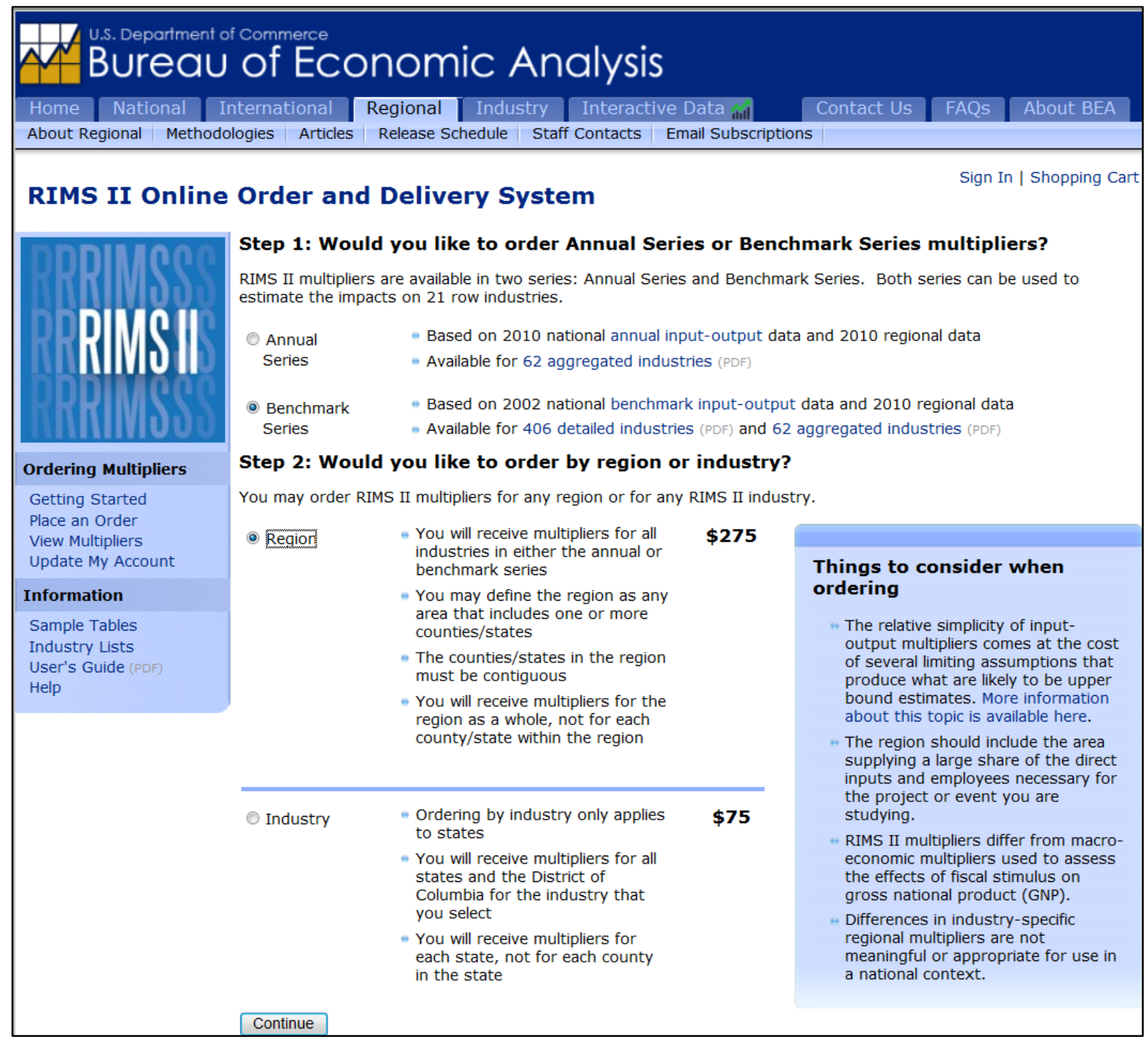

\section{Figure 3-11. RIMS II Page for Selecting Order Options}

Before continuing, check the year of regional data used in deriving the current Benchmark Series multipliers against the date that the transit service under consideration first started. The transit service must have started no later than this year of regional data for the multipliers.

Once the order options have been selected, click the "Continue" button at the bottom. Follow the other steps to specify the region of interest, establish an account, and pay for the order. 


\section{Selecting the Required Multipliers}

After the order has been placed, an e-mail notification will be sent indicating when the multipliers are available at the RIMS II website. Access the multipliers either by directly viewing them at the site or by downloading the tables that contain the multipliers.

The multipliers ordered for the region are available in four tables, with two tables for Type I multipliers and two for Type II multipliers. The Type I multipliers account for the direct and indirect impacts based on the supply of goods and services in the region. The Type II multipliers account for these same direct and indirect impacts as well as for induced impacts that are associated with the purchases made by employees. Type II multipliers are needed.

One table for Type II multipliers, Table 1.5, provides multipliers for 402 detailed industries. The other table for Type II multipliers, Table 2.5, provides multipliers for 62 aggregated industries. Up to six multipliers will be needed from Table 1.5 and up to two multipliers from Table 2.5. The specific industries from each table were discussed in the previous section on input data. Each of these two tables of Type II multipliers includes six types of multipliers-four final-demand multipliers and two direct-effect multipliers. The four finaldemand multipliers are needed.

Figure 3-12 shows the first page of Table 1.5, and Figure 3-13 shows the first page of Table 2.5 for Orange County, Florida. Note that the final-demand multipliers appear in the middle columns of each table. The years in the table titles-2002/2008, in this case-represent the year of national data and regional data used in deriving the multipliers. The year of regional data used may be needed. 
RIMS II Multipliers (2002/2008)

Table 1.5 Total Multipliers for Output, Earnings, Employment, and Value Added by Detailed Industry Orange, FL (Type II)

\begin{tabular}{|c|c|c|c|c|c|c|}
\hline \multirow{3}{*}{ INDUSTRY } & \multicolumn{6}{|c|}{ Multiplier } \\
\hline & \multicolumn{4}{|c|}{ Final Demand } & \multicolumn{2}{|c|}{ Direct Effect } \\
\hline & $\begin{array}{l}\text { Output/1/ } \\
\text { (dollars) }\end{array}$ & \begin{tabular}{|c|} 
Earnings/2/ \\
(dollars)
\end{tabular} & \begin{tabular}{|c|} 
Employment $/ 3 /$ \\
(jobs)
\end{tabular} & \begin{tabular}{|c} 
Value-added/4/ \\
(dollars)
\end{tabular} & $\begin{array}{c}\text { Earnings/5/ } \\
\text { (dollars) }\end{array}$ & $\begin{array}{c}\text { Employment } / 6 \text {. } \\
\text { (jobs) }\end{array}$ \\
\hline 1111C0 Oilseed and grain farming & 1.0000 & 0.0000 & 0.0000 & 0.0000 & 0.0000 & 0.0000 \\
\hline 111200 Vegetable and melon farming & 1.5757 & 0.2303 & 10.9266 & 0.8493 & 1.9350 & 1.5025 \\
\hline $1113 \mathrm{~B} 0$ Fruit and tree nut farming & 1.5758 & 0.2669 & 10.9071 & 0.8642 & 1.7939 & 1.5055 \\
\hline 111400 Greenhouse, nursery, and floriculture production & 1.5978 & 0.3039 & 12.2331 & 0.9901 & 1.6344 & 1.4596 \\
\hline 111910 Tobacco farming & 1.0000 & 0.0000 & 0.0000 & 0.0000 & 0.0000 & 0.0000 \\
\hline 111920 Cotton farming & 1.0000 & 0.0000 & 0.0000 & 0.0000 & 0.0000 & 0.0000 \\
\hline $\begin{array}{l}\text { 1119C0 All other crop farming, including sugarcane and } \\
\text { sugar beet farming }\end{array}$ & 1.6994 & 0.2272 & 7.2046 & 0.7479 & 2.3705 & 2.4478 \\
\hline $1121 \mathrm{~A} 0$ Cattle ranching and farming & 1.3626 & 0.1486 & 4.6589 & 0.4052 & 1.8361 & 1.8283 \\
\hline 112120 Dairy cattle and milk production & 1.4120 & 0.1737 & 5.9301 & 0.6453 & 1.8639 & 1.6708 \\
\hline $\begin{array}{l}\text { 112A00 Animal production, except cattle and poultry and } \\
\text { eggs }\end{array}$ & 1.3283 & 0.1549 & 5.5184 & 0.7143 & 1.7286 & 1.5774 \\
\hline 112300 Poultry and egg production & 1.3541 & 0.1544 & 4.4544 & 0.4009 & 1.9078 & 1.7937 \\
\hline $113 \mathrm{~A} 00$ Forest nurseries, forest products, and timber tracts & 1.5599 & 0.2170 & 6.5870 & 0.7176 & 2.5839 & 2.9667 \\
\hline 113300 Logging & 1.0000 & 0.0000 & 0.0000 & 0.0000 & 0.0000 & 0.0000 \\
\hline 114100 Fishing & 1.0000 & 0.0000 & 0.0000 & 0.0000 & 0.0000 & 0.0000 \\
\hline 114200 Hunting and trapping & 1.5454 & 0.2210 & 13.0247 & 0.7762 & 2.1059 & 1.3309 \\
\hline 115000 Support activities for agriculture and forestry & 1.8022 & 0.5020 & 20.9752 & 1.0243 & 1.4528 & 1.2533 \\
\hline 211000 Oil and gas extraction & 1.0000 & 0.0000 & 0.0000 & 0.0000 & 0.0000 & 0.0000 \\
\hline 212100 Coal mining & 1.0000 & 0.0000 & 0.0000 & 0.0000 & 0.0000 & 0.0000 \\
\hline 212210 Iron ore mining & 1.0000 & 0.0000 & 0.0000 & 0.0000 & 0.0000 & 0.0000 \\
\hline 2122A0 Gold, silver, and other metal ore mining & 1.0000 & 0.0000 & 0.0000 & 0.0000 & 0.0000 & 0.0000 \\
\hline 212230 Copper, nickel, lead, and zinc mining & 1.0000 & 0.0000 & 0.0000 & 0.0000 & 0.0000 & 0.0000 \\
\hline 212310 Stone mining and quarrying & 1.5059 & 0.1644 & 3.7815 & 0.8556 & 3.1016 & 3.4449 \\
\hline $\begin{array}{l}212320 \text { Sand, gravel, clay, and ceramic and refractory } \\
\text { minerals mining and quarrying }\end{array}$ & 1.5274 & 0.1712 & 3.9463 & 0.8287 & 3.0339 & 3.2581 \\
\hline 212390 Other nonmetallic mineral mining and quarrying & 1.4955 & 0.1524 & 3.1705 & 0.8106 & 3.2266 & 4.8584 \\
\hline 213111 Drilling oil and gas wells & 1.7273 & 0.3956 & 12.3565 & 0.9159 & 1.6503 & 1.4667 \\
\hline 213112 Support activities for oil and gas operations & 1.9307 & 0.5019 & 14.8856 & 1.0092 & 1.6693 & 1.5539 \\
\hline 21311A Support activities for other mining & 2.0210 & 0.4794 & 14.6356 & 0.9446 & 1.8501 & 1.6227 \\
\hline $\begin{array}{l}\text { 2211A0 Electric power generation, transmission, and } \\
\text { distribution }\end{array}$ & 1.3767 & 0.2211 & 3.8836 & 0.9124 & 1.5864 & 2.4892 \\
\hline 221200 Natural gas distribution & 1.2675 & 0.1252 & 2.5946 & 0.4932 & 1.7974 & 2.4110 \\
\hline 221300 Water, sewage and other systems & 1.6922 & 0.3220 & 7.5815 & 1.0810 & 1.8759 & 2.1773 \\
\hline 230000 Construction & 1.7798 & 0.3953 & 10.5463 & 0.9664 & 1.6904 & 1.7567 \\
\hline 311111 Dog and cat food manufacturing & 1.0000 & 0.0000 & 0.0000 & 0.0000 & 0.0000 & 0.0000 \\
\hline 311119 Other animal food manufacturing & 1.0000 & 0.0000 & 0.0000 & 0.0000 & 0.0000 & 0.0000 \\
\hline 311210 Flour milling and malt manufacturing & 1.0000 & 0.0000 & 0.0000 & 0.0000 & 0.0000 & 0.0000 \\
\hline 311221 Wet corn milling & 1.0000 & 0.0000 & 0.0000 & 0.0000 & 0.0000 & 0.0000 \\
\hline 31122A Soybean and other oilseed processing & 1.0000 & 0.0000 & 0.0000 & 0.0000 & 0.0000 & 0.0000 \\
\hline
\end{tabular}

Figure 3-12. RIMS II Table 1.5 
RIMS II Multipliers (2002/2008)

Table 2.5 Total Multipliers for Output, Earnings, Employment, and Value Added by Industry Aggregation Orange, FL (Type II)

\begin{tabular}{|c|c|c|c|c|c|c|}
\hline \multirow{3}{*}{ INDUSTRY } & \multicolumn{6}{|c|}{ Multiplier } \\
\hline & \multicolumn{4}{|c|}{ Final Demand } & \multicolumn{2}{|c|}{ Direct Effect } \\
\hline & \begin{tabular}{|l}
$\begin{array}{l}\text { Output/1/ } \\
\text { (dollars) }\end{array}$ \\
\end{tabular} & \begin{tabular}{|c|}
$\begin{array}{c}\text { Earnings/2/ } \\
\text { (dollars) }\end{array}$ \\
\end{tabular} & $\begin{array}{c}\text { Employment/3/ } \\
\text { (jobs) }\end{array}$ & $\begin{array}{c}\text { Value-added/4/ } \\
\text { (dollars) }\end{array}$ & \begin{tabular}{|c|}
$\begin{array}{c}\text { Earnings/5/ } \\
\text { (dollars) }\end{array}$ \\
\end{tabular} & $\begin{array}{c}\text { Employment/6 } \\
\text { (jobs) }\end{array}$ \\
\hline 1. Crop and animal production & 1.5889 & 0.2939 & 12.1751 & 0.6688 & 1.6209 & 1.4261 \\
\hline 2. Forestry, fishing, and related activities & 1.6323 & 0.3174 & 12.2639 & 0.7995 & 1.6940 & 1.4156 \\
\hline 3. Oil and gas extraction & 1.0000 & 0.0000 & 0.0000 & 0.0000 & 0.0000 & 0.0000 \\
\hline 4. Mining, except oil and gas & 1.5091 & 0.1622 & 3.5760 & 0.8320 & 3.1690 & 4.0813 \\
\hline 5. Support activities for mining & 1.9802 & 0.4973 & 15.1948 & 1.0494 & 1.7989 & 1.6205 \\
\hline 6. Utilities* & 1.3796 & 0.2187 & 4.0067 & 0.8284 & 1.5920 & 2.4329 \\
\hline 7. Construction & 1.7788 & 0.3974 & 10.6489 & 0.9696 & 1.6995 & 1.7738 \\
\hline 8. Wood product manufacturing & 1.6005 & 0.2564 & 6.9108 & 0.6566 & 1.9750 & 1.9257 \\
\hline 9. Nonmetallic mineral product manufacturing & 1.6531 & 0.2868 & 6.7176 & 0.8255 & 1.9275 & 2.1623 \\
\hline 10. Primary metal manufacturing & 1.5812 & 0.1955 & 4.5442 & 0.6335 & 2.4405 & 2.7606 \\
\hline 11. Fabricated metal product manufacturing & 1.6388 & 0.2755 & 6.8895 & 0.8047 & 1.9174 & 2.0425 \\
\hline 12. Machinery manufacturing & 1.5807 & 0.2443 & 5.4712 & 0.7340 & 2.0088 & 2.3006 \\
\hline 13. Computer and electronic product manufacturing & 1.8420 & 0.3185 & 6.2474 & 0.8590 & 2.3713 & 3.3012 \\
\hline 14. Electrical equipment and appliance manufacturing & 1.6252 & 0.2860 & 6.8032 & 0.8068 & 1.8829 & 1.9747 \\
\hline 15. Motor vehicle, body, trailer, and parts manufacturing & 1.6071 & 0.2560 & 5.8741 & 0.6154 & 2.0234 & 2.1961 \\
\hline 16. Other transportation equipment manufacturing & 1.9783 & 0.3936 & 8.7497 & 0.9574 & 2.3186 & 3.0889 \\
\hline 17. Furniture and related product manufacturing & 1.6695 & 0.3033 & 8.5135 & 0.8097 & 1.8308 & 1.7776 \\
\hline 18. Miscellaneous manufacturing & 1.6968 & 0.3679 & 8.6950 & 0.9166 & 1.6584 & 1.8310 \\
\hline 19. Food, beverage, and tobacco product manufacturing & 1.6941 & 0.2357 & 5.6880 & 0.6691 & 2.5112 & 2.6134 \\
\hline 20. Textile and textile product mills & 1.4941 & 0.2103 & 5.9029 & 0.6142 & 1.9744 & 1.8724 \\
\hline 21. Apparel, leather, and allied product manufacturing & 1.7790 & 0.4559 & 15.5925 & 0.8743 & 1.5994 & 1.4308 \\
\hline 22. Paper manufacturing & 1.5472 & 0.2412 & 5.0642 & 0.7020 & 1.9472 & 2.4490 \\
\hline 23. Printing and related support activities & 1.7035 & 0.3562 & 9.7081 & 0.8988 & 1.7346 & 1.7519 \\
\hline 24. Petroleum and coal products manufacturing & 1.5016 & 0.1863 & 3.9274 & 0.4096 & 2.4527 & 3.0570 \\
\hline 25. Chemical manufacturing & 1.7343 & 0.2583 & 5.2798 & 0.7695 & 2.6188 & 3.4722 \\
\hline 26. Plastics and rubber products manufacturing & 1.4783 & 0.1997 & 5.1386 & 0.6642 & 1.9510 & 1.9574 \\
\hline 27. Wholesale trade & 1.6729 & 0.3573 & 7.5984 & 1.0943 & 1.6996 & 2.1682 \\
\hline 28. Retail trade & 1.7052 & 0.3870 & 13.7366 & 1.0942 & 1.5909 & 1.4511 \\
\hline 29. Air transportation & 1.7110 & 0.3493 & 8.2046 & 0.8807 & 1.7626 & 2.2626 \\
\hline 30. Rail transportation & 1.7655 & 0.3174 & 6.4056 & 0.9576 & 2.0724 & 3.4159 \\
\hline 31. Water transportation & 1.7816 & 0.2786 & 6.3292 & 0.7835 & 2.5542 & 4.2399 \\
\hline 32. Truck transportation & 1.8444 & 0.3664 & 10.1742 & 0.9766 & 2.0726 & 2.1987 \\
\hline 33. Transit and ground passenger transportation ${ }^{*}$ & 1.8698 & 0.4093 & 15.1490 & 0.8481 & 1.8580 & 1.5219 \\
\hline 34. Pipeline transportation & 1.9092 & 0.3538 & 7.5588 & 0.8108 & 2.3172 & 4.2705 \\
\hline 35. Other transportation and support activities ${ }^{\star}$ & 1.7624 & 0.4570 & 12.0173 & 1.1158 & 1.5750 & 1.7022 \\
\hline 36. Warehousing and storage & 1.8991 & 0.5225 & 15.2024 & 1.1779 & 1.5653 & 1.6109 \\
\hline 37. Publishing industries, except Internet & 1.8142 & 0.3828 & 8.9364 & 1.0629 & 1.8700 & 2.3157 \\
\hline 38. Motion picture and sound recording industries & 1.7172 & 0.3169 & 9.2531 & 1.0361 & 1.8657 & 1.8748 \\
\hline 39. Broadcasting, except Internet & 2.1398 & 0.4665 & 8.8993 & 1.1202 & 2.0594 & 3.8977 \\
\hline
\end{tabular}

Figure 3-13. RIMS II Table 2.5 


\section{Obtaining Spending Data}

This sub-section provides detailed guidance for obtaining the input data on the following items:

- unemployment rate

- total O\&M spending

- total capital spending for each project category

- distribution of spending across sources of funds

- distribution of spending across destinations of spending

- distribution of debt repayments across sources of funds

An important source of data for many of these items is the National Transit Database (NTD), which is described before presenting the guidance for obtaining these data items.

\section{NTD}

Almost all providers of urban transit services report to the NTD annual data about their systems, amount of services, use of these services, and revenues and expenses. Only revenues and expense data are relevant for using this tool. NTD can provide most of the spending data necessary for use of this tool to estimate the economic impacts of spending on existing services.

There are two main options for assessing NTD data:

1. Integrated National Transit Database Analysis System (INTDAS), available at http://www.ftis.org/intdas.html, contains most of the raw NTD data reported by transit agencies since 1984. While requiring registration and login, it is simple to use and flexible in selecting the exact data needed.

2. Annual data tables at http://www.ntdprogram.gov/ntdprogram/data.htm also contain the raw NTD data reported by transit agencies. Each of these tables is a large Excel worksheet that covers the data related to a particular subject for all agencies. To use data from these tables, identify which table has the data needed; for example, data on capital spending by project category are in Table 11, Capital Funds Applied by Type of Expenditure.

Option 1, INTDAS, is the best in most cases. However, Option 2 may be best under the following circumstances:

- It is not desirable to register and log in to use INTDAS and learn to use it.

- INTDAS does not cover the particular NTD data needed. For example, the data on capital spending by project category are not available in INTDAS. 
It is important to point out that the NTD data are organized by transit service providers but not by geographies (counties, metropolitan areas, etc.). The data required for this tool must be organized by geography. Before getting data from NTD, this issue would need to be resolved. The simplest case is one in which the study area is served by only one transit agency and covers all services of that agency. In this case, NTD data for this single area may be used for the study area. A slightly more complicated but still straightforward case is one in which the study area is served by more than one agency and covers all services of these agencies. In this case, NTD data for these different agencies would need to be aggregated. A complicated case is one in which the study area covers only a portion of the services provided by one or more transit agencies. Additional information beyond that provided by NTD would need to be used in attributing the NTD data for these agencies to the study area. Consider the desire of estimating the economic impacts of spending on transit for providing the transit service by LYNX for each of the counties LYNX servesOrange, Osceola, and Seminole.

In trying to resolve this issue of possible mismatching between agency-level data in the NTD and geography-level data needs for using this tool, it is important to understand a significant difference in data needs between estimating the transportation benefits of transit services and estimating the economic impacts of spending for transit services. For estimating transportation benefits, it is essential to know where the transit service is provided. For estimating economic impacts, it is essential to know the following:

- Where the employees of the transit agency live

- Where the money comes from (source of funds)

- Where the money is spent (destination of spending)

For example, the spending by LYNX for providing its services would have no economic impacts (positive or negative) on the Osceola County economy if the following were true:

- No LYNX employees live in Osceola County.

- No LYNX revenues come from Osceola County (not likely because some fare revenues would come from residents of the county).

- LYNX does not spend any money for purchasing goods or services produced in Osceola County.

\section{Unemployment}

The Local Area Unemployment Statistics page of the U.S. Bureau of Labor Statistics web site, http://www.bls.gov/lau/tables.htm, provides estimates of annual average unemployment rates for individual states, metropolitan areas, and counties. 


\section{Total O\&M Spending}

Data on total O\&M operating are readily available from the NTD. Through INTDAS, Total Operating Expense can be selected from the list of Florida Standard Variables (near the upper right corner in Figure 3-14). The data are available separately for each mode. Alternatively, Table 12 (Transit Operating Expenses by Mode, Type of Service and Function) or Table 13 (Transit Operating Expenses by Mode, Type of Service and Object Class) from Option 2 for accessing NTD data discussed earlier can be used. The last column of both tables shows the total O\&M expense for each mode and for all modes combined.

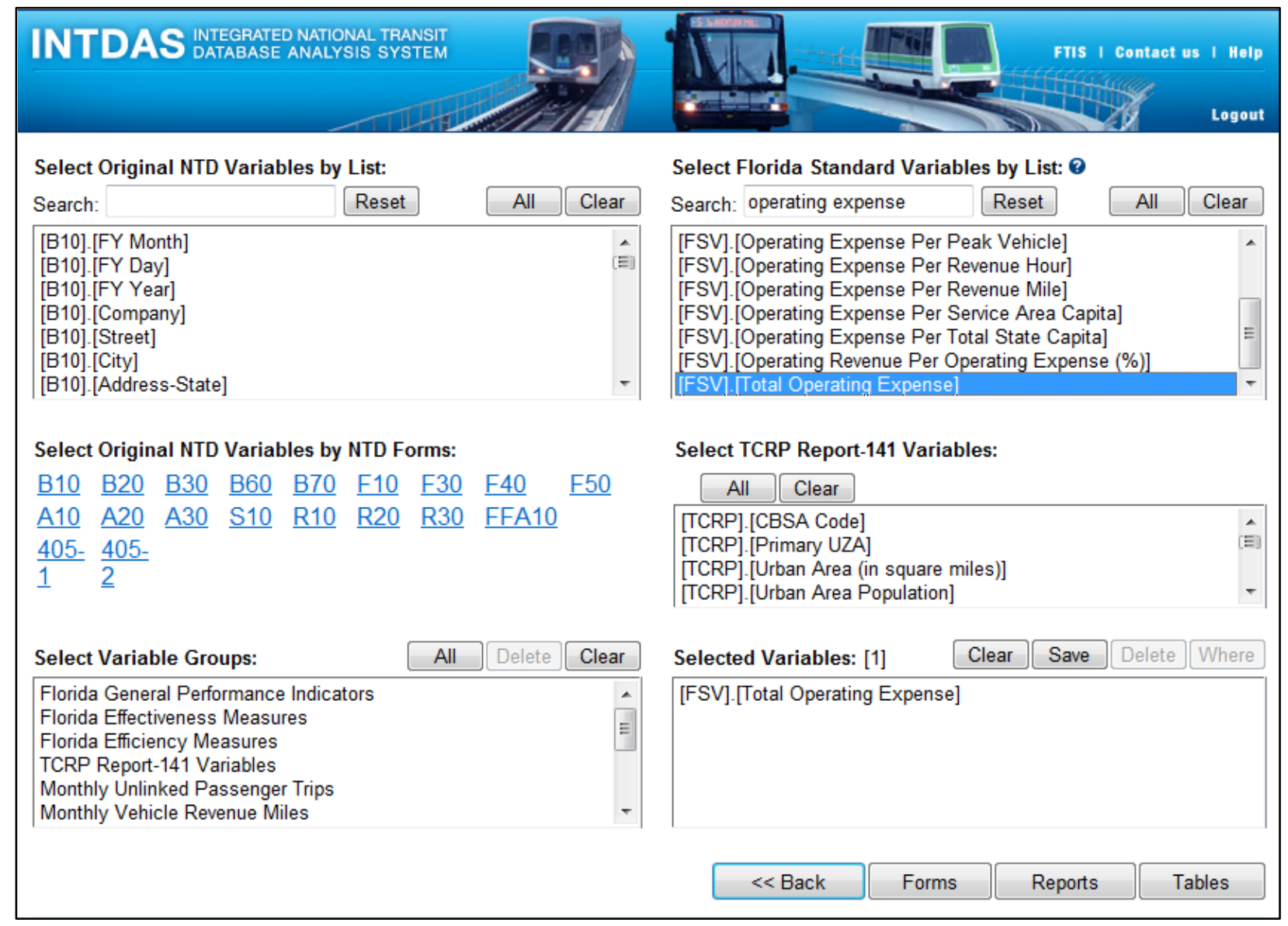

Figure 3-14. Selecting Florida Standard Variables in INTDAS

\section{Capital Spending by Project Category}

Start building the data on capital spending by project category with annual data in Table 11, Capital Funds Applied by Type of Expenditure. While the exact labels may change slightly over time, the following nine project categories are currently used by the NTD Reporting Manual for capital spending data:

1. Guideway

2. Passenger Stations (or Stations in Table 11) 


\section{Administrative Buildings}

4. Maintenance Buildings (or Facilities in Table 11)

5. Other

6. Revenue Vehicles (or Rolling Stock in Table 11)

7. Service Vehicles (or Other Vehicles in Table 11)

8. Fare Revenue Collection Systems

9. Communications and Information Systems

The first five categories may be grouped as construction projects. Category 5, Other, includes furniture and equipment that are not an integral part of buildings and structures as well as shelters, signs, and passenger amenities (e.g., benches) not in passenger stations. The spending for these construction projects includes the costs for design and engineering, land acquisition and relocation, demolition, and purchase or construction of the structures.

When possible, the data to be entered into the tool should have land cost removed from each of the construction categories and added as a separate category. Similarly, the data entered into the tool should have the cost for design and engineering removed from each of the construction categories and added as a separate category. In addition, the data needed for the tool should separate bus revenue vehicles from rail revenue vehicles. The following are some guidelines for making adjustments to the NTD data directly from Table 11:

- Use the original NTD data if the amount of land cost for any category of construction projects cannot be determined.

- Use the original NTD data if the amount of design and engineering cost for any category of construction projects cannot be determined.

- If only bus (or rail) revenue vehicles are involved, assign all spending on revenue vehicles to the bus (or rail) category.

- If both bus and rail revenue vehicles are involved, split the total spending on revenue vehicles between bus and rail.

\section{Distribution of Spending across Sources of Funds}

Develop the distribution of spending across sources through INTDAS. Once entered, select the year(s), mode(s), agencies, and service type, as shown in Figure 3-15. 


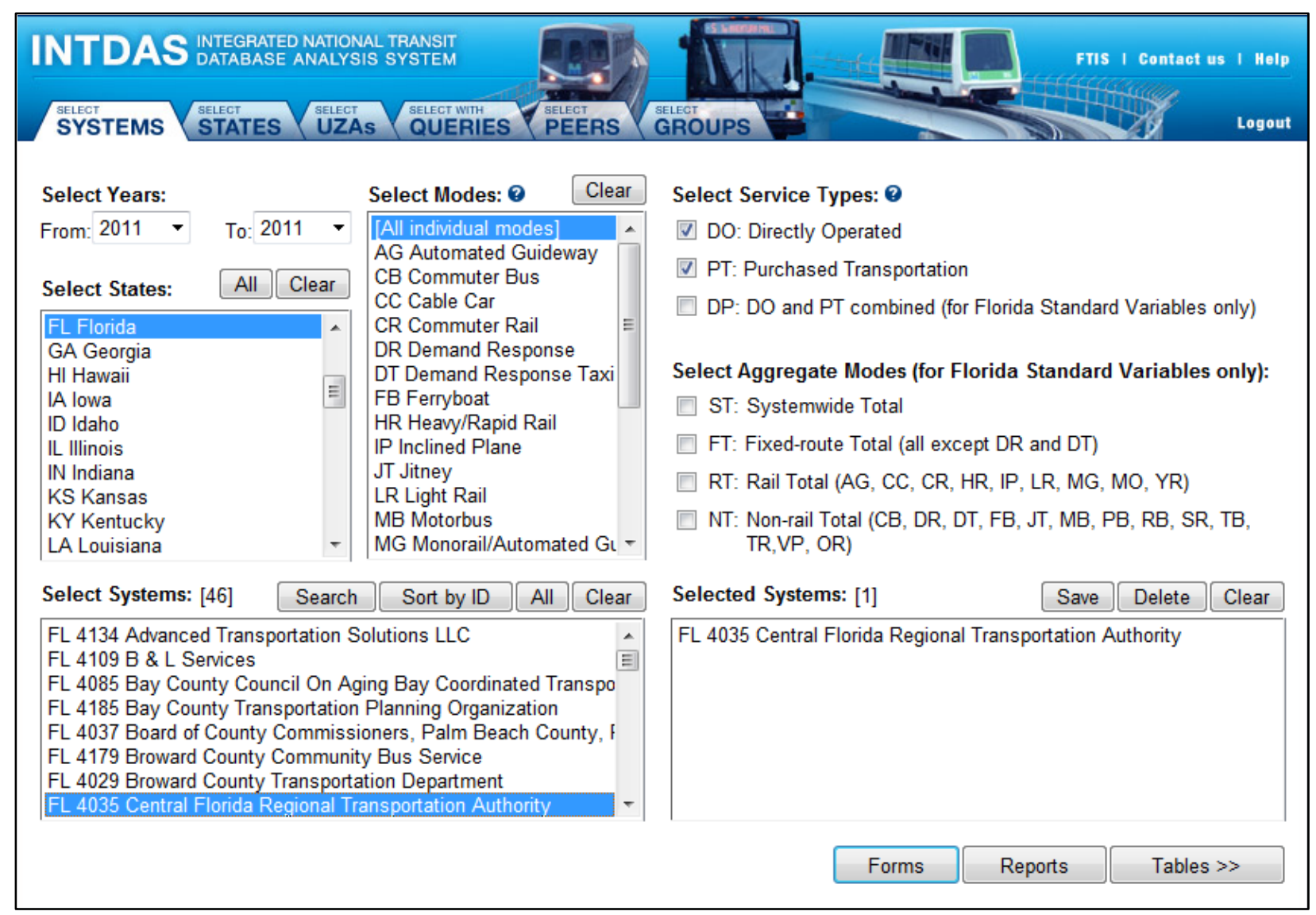

Figure 3-15. Selecting Year, Mode, Agency, and Service Type in INTDAS

Next, select the relevant variables from the screen in Figure 3-16 after clicking the Tables button in the previous screen (Figure 3-15). 


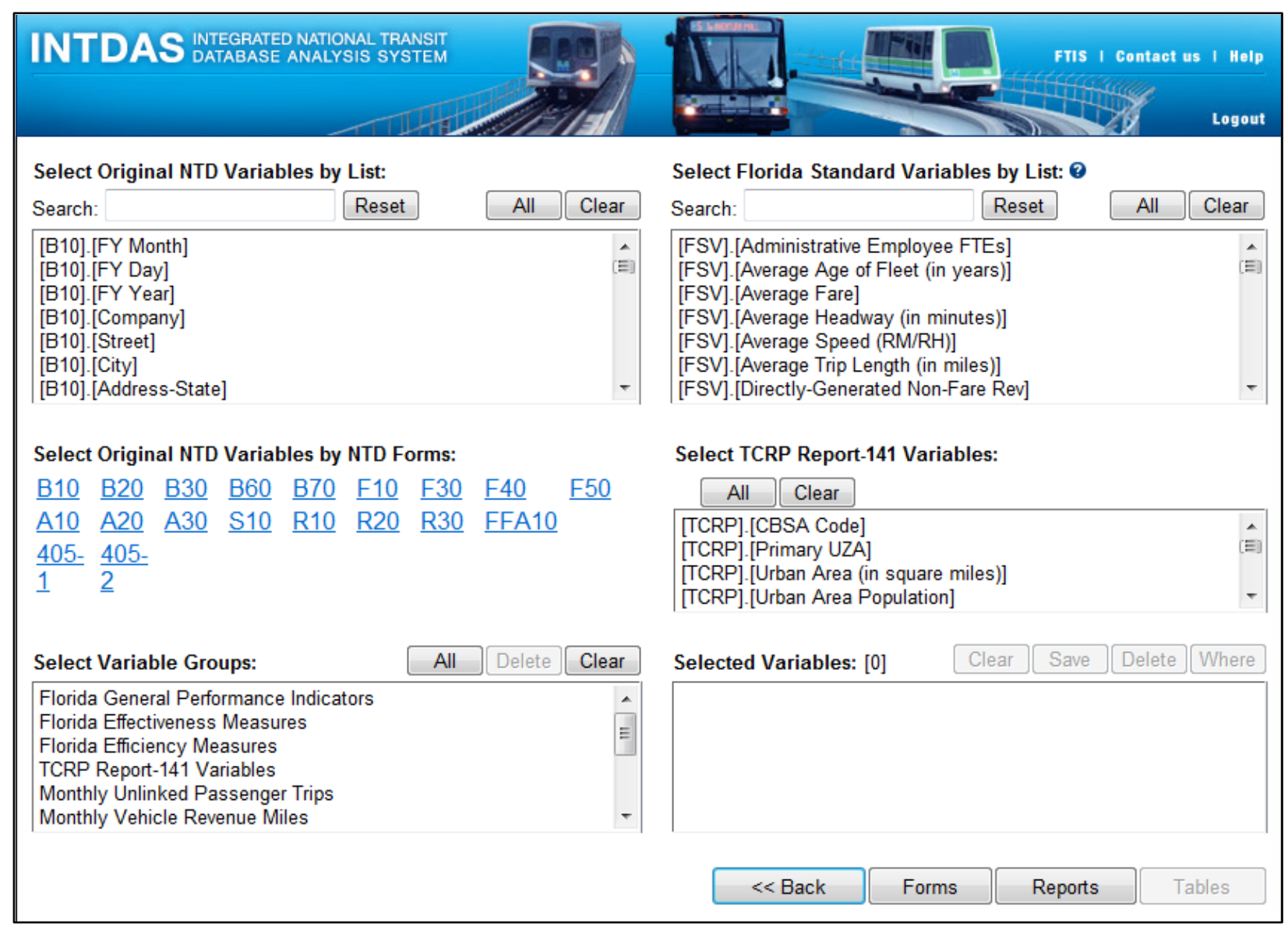

\section{Figure 3-16. Selecting Variables in INTDAS}

Selecting variables from Form F10 is the easiest method. Once the F10 button is clicked, the form opens and its top portion appears, as shown in Figure 3-17. Select both the column for Funds Expended on Operations and the column for Funds Expended on Capital for the following four rows:

- $\quad$ 30. Total Directly Generated Funds

- $\quad$ 43. Total Local Funds

- $\quad$ 56. Total State Funds

- 86. Total Federal Funds

Save the data from INTDAS and use them to determine the distribution of total O\&M spending in terms of its source of funds between inside the study area and outside the study area. Both Total Directly Generated Funds and Total Local Funds would be considered to be from inside the study area and Total Federal Funds would always be considered to be from outside the study area. Total State Funds would be treated as being from outside the study area if the study area is smaller than a state but from inside the study area if the study area is an entire state. 


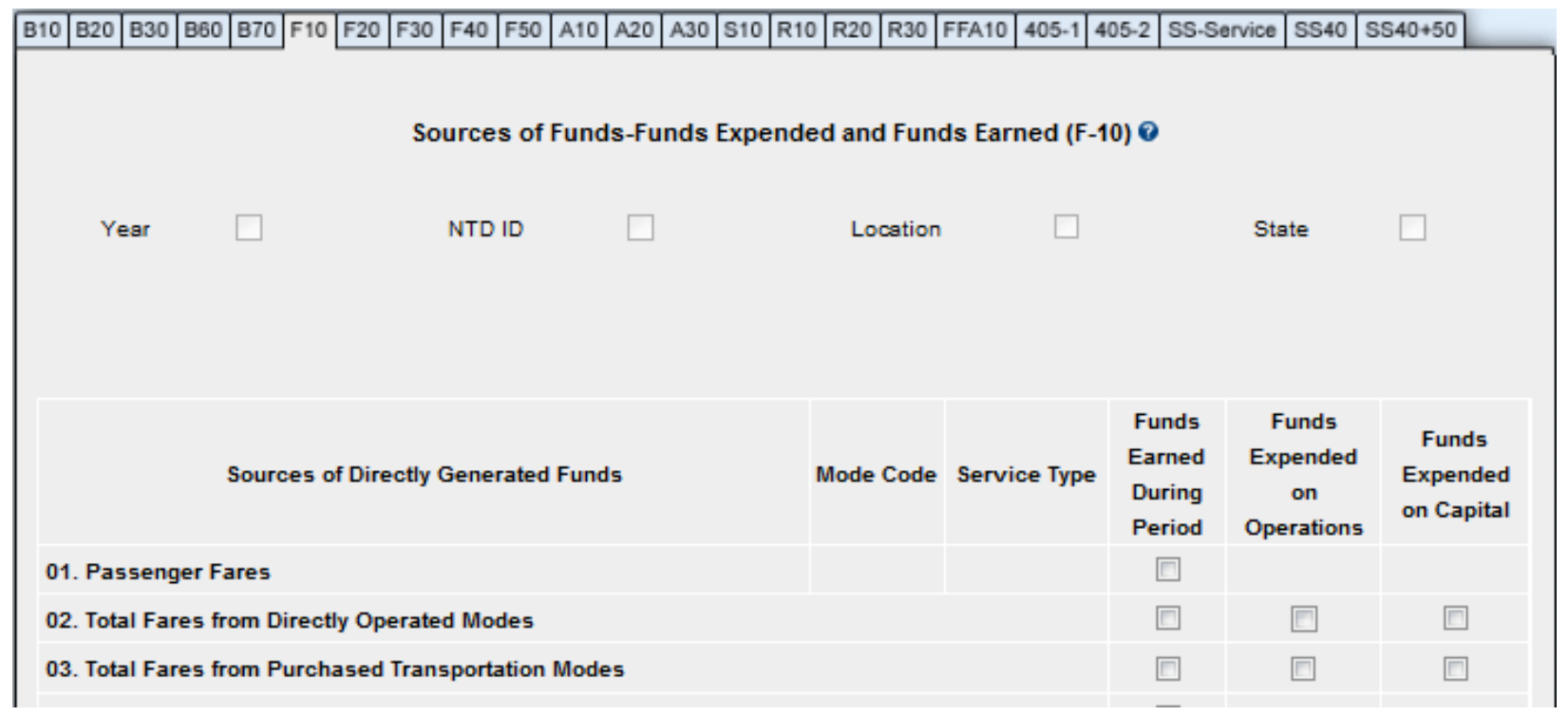

Figure 3-17. Form F10 in INTDAS

Use the above data from INTDAS to determine the distribution of total capital spending. The tool requires distribution for each project category using two available options:

- Apply the distribution for total capital spending to each category. This option is not fully satisfactory for two reasons: 1) federal funds are more likely to be used for some categories of capital projects than others and 2) spending on some categories of capital projects (such as revenue vehicles) is more likely to be made outside the study area than others (such as administrative buildings).

- Determine the distribution for each project category using more detailed data from the transit agency.

\section{Distribution of Spending across Destinations of Spending}

This distribution indicates the degree to which money is spent inside the study area vs. outside the study area. Money spent outside the study area does not support or create any economic activity inside the study area. NTD data cannot be used for obtaining data on this distribution. This distribution is needed for each of the following:

- Total non-financed O\&M spending

- Non-financed capital spending for each project category

- Total financed O\&M spending

- Financed capital spending for each project category

Two options are available for determining spending distributions:

- Access the detailed and complete agency records to determining exactly where the money was spent. This is ideal, but may not be feasible. 
- Estimate the distribution with incomplete agency records. The estimated distribution does not have to be exact but it should reflect the relative magnitudes between the destinations.

- For capital spending, there likely are general patterns in the relative magnitudes between the sources (inside vs. outside the study area). For example, the vast majority of transit agencies buy their rolling stock, fare collection systems, and communications and information systems from outside the local economy simply because the local economy does not make these products. On the other hand, it is reasonable to assume that most of the money for construction projects is spent in the local economy. Table 3-1 shows the default distributions of capital spending by project category if local estimates are not available.

- For total O\&M spending, the distribution may be approximated by the distribution of the residences of agency employees. Most transit agencies probably know the residence county of each employee.

Table 3-1. Default Distributions of Capital Spending by Destination

\begin{tabular}{|l|l|l|}
\hline Category of Capital Projects & $\begin{array}{l}\text { Outside } \\
\text { Study Area }\end{array}$ & $\begin{array}{l}\text { Inside } \\
\text { Study Area }\end{array}$ \\
\hline Land Cost & $0 \%$ & $100 \%$ \\
\hline Design and Engineering & $50 \%$ & $50 \%$ \\
\hline Guideway (net of land cost) & $25 \%$ & $75 \%$ \\
\hline Passenger Stations (net of land cost) & $0 \%$ & $100 \%$ \\
\hline Administrative Buildings (net of land cost) & $0 \%$ & $100 \%$ \\
\hline Maintenance Facilities (net of land cost) & $25 \%$ & $75 \%$ \\
\hline Other Capital Projects (net of land cost) & $0 \%$ & $100 \%$ \\
\hline Revenue Vehicles - Bus & $100 \%$ & $0 \%$ \\
\hline Revenue Vehicles - Rail & $100 \%$ & $0 \%$ \\
\hline Service Vehicles & $100 \%$ & $0 \%$ \\
\hline Fair Revenue Collection Systems & $100 \%$ & $0 \%$ \\
\hline Communications and Information Systems & $100 \%$ & $0 \%$ \\
\hline
\end{tabular}

\section{Distribution of Debt Repayments across Sources of Funds}

For total O\&M spending or each project category of capital spending, data are not needed on the distribution of debt repayments if spending originated from borrowed funds through bonds and loans has not been entered. Otherwise, two options are available:

- Obtain distributions from agency data. Each agency must have the necessary data to determine such distributions, but it may take some effort to identify and assemble the data. For years before 2011, use INTDAS to determine the distribution of debt repayments for capital projects or for O\&M. For example, the distributions in Table 3-2 were derived from INTDAS for 2010 and all transit agencies. 
Table 3-2. Distribution of Debt Repayments for

All Agencies in 2010 NTD

\begin{tabular}{|l|l|l|}
\hline Source of Funds & Total O\&M & Total Capital \\
\hline Directly-generated & $27.4 \%$ & $56.3 \%$ \\
\hline Local government & $51.1 \%$ & $9.7 \%$ \\
\hline State government & $16.8 \%$ & $23.2 \%$ \\
\hline Federal government & $4.8 \%$ & $10.8 \%$ \\
\hline
\end{tabular}

- Assume that all debt repayments use funds from inside the study area if estimating such distributions from agency data is not possible. The consequence of making this simplifying assumption is more conservative estimates of economic impacts from this tool.

If any spending from borrowed funds for any of these spending categories was entered, data on the distribution of debt repayments for this category are required. One possibility may be to use the distribution of spending across its sources of funds as the distribution of debt repayments. At least at the national level, however, the distribution of spending across its sources of fund differs significantly from the distribution of debt repayments. Excluding bonds and loans as one source of spending, Table 3-3 is based on 2010 NTD data and shows the distribution of spending across its sources of fund.

Table 3-3. Distribution of Spending on Transit for All Agencies in 2010 NTD

\begin{tabular}{|l|l|l|}
\hline Source of Funds & Total O\&M & Total Capital \\
\hline Directly-generated & $37.5 \%$ & $0.6 \%$ \\
\hline Local government & $28.1 \%$ & $44.0 \%$ \\
\hline State government & $24.9 \%$ & $14.2 \%$ \\
\hline Federal government & $9.4 \%$ & $41.2 \%$ \\
\hline
\end{tabular}




\section{Chapter 4 - Applications to Central Florida}

District 5 of the Florida Department of Transportation (FDOT) requested that estimates be conducted of the economic impacts of spending on public transit for each county in District 5 (Brevard, Lake, Marion, Orange, Osceola, Seminole, and Volusia) that either has existing transit service or has proposed transit service for the near future. This section applies the tool to these counties when feasible and proper.

\section{FDOT District 5 Transit Agencies}

Five transit agencies provide urban transit service in FDOT District 5. Table 4-1 shows the counties served, modes operated, and system-total revenue vehicle miles provided by each agency. All agencies provided transit service in 2008. Figure 4-1 is a map of showing the counties in District 5.

Table 4-1. Summary of Transit Agencies in District 5

\begin{tabular}{|l|l|l|l|}
\hline Transit Agency & Counties Served & Modes Operated & $\begin{array}{l}\text { Revenue Vehicle } \\
\text { Miles Provided* }\end{array}$ \\
\hline LakeXpress & Lake & $\begin{array}{l}\text { Fixed-route bus } \\
\text { Demand response }\end{array}$ & $2,229,240$ \\
\hline LYNX Transit & $\begin{array}{l}\text { Orange } \\
\text { Osceola } \\
\text { Seminole }\end{array}$ & $\begin{array}{l}\text { Fixed-route bus } \\
\text { Demand response } \\
\text { Vanpool }\end{array}$ & $24,583,550$ \\
\hline $\begin{array}{l}\text { Space Coast Area } \\
\text { Transit (SCAT) }\end{array}$ & Brevard & $\begin{array}{l}\text { Fixed-route bus } \\
\text { Demand response } \\
\text { Vanpool }\end{array}$ & $4,124,518$ \\
\hline $\begin{array}{l}\text { SunTran } \\
\text { County of Volusia } \\
\text { dba VOTRAN }\end{array}$ & Volusia & $\begin{array}{l}\text { Fixed-route bus } \\
\text { Demand response }\end{array}$ & 449,019 \\
\hline $\begin{array}{l}\text { *2007 NTD for SunTran, 2011 NTD for } \text { other agencies. Data accessed using INTDAS at } \\
\text { http://www.ftis.org/intdas.html. }\end{array}$ & $\begin{array}{l}\text { Fixed-route bus } \\
\text { Vemand response }\end{array}$ \\
\hline
\end{tabular}

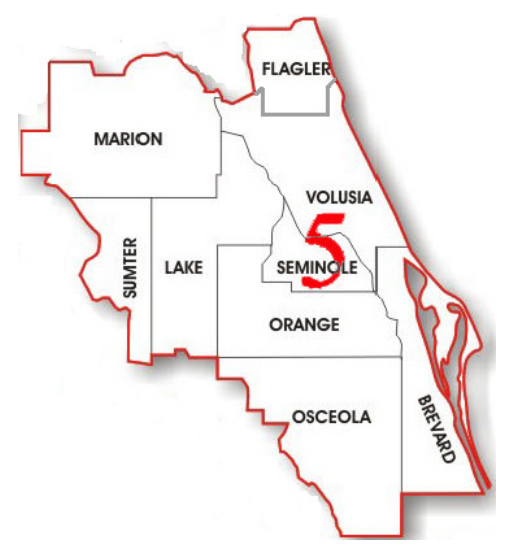

Figure 4-1. Map of FDOT District 5 
District 5 also requested that the study consider Flagler and Sumter counties. Each county is planning for new urban transit service, and the request was to study the economic impacts of spending on the planned service. Table 4-2 shows the 2011 characteristics of all of these counties in terms of population, employment, and unemployment rates.

Table 4-2. Characteristics of Study Counties

\begin{tabular}{|l|l|l|l|}
\hline $\begin{array}{l}\text { Counties } \\
\text { Served }\end{array}$ & $\begin{array}{l}\text { Population } \\
\text { (April 1, 2011) }\end{array}$ & $\begin{array}{l}\text { Employment } \\
(\mathbf{2 0 1 1} \text { average) }\end{array}$ & $\begin{array}{l}\text { Unemployment Rate } \\
(\mathbf{2 0 1 1} \text { average })\end{array}$ \\
\hline Brevard & 545,184 & 240,267 & $10.7 \%$ \\
\hline Flagler & 96,241 & 30,348 & $13.5 \%$ \\
\hline Lake & 298,265 & 114,139 & $11.0 \%$ \\
\hline Marion & 331,745 & 117,710 & $12.0 \%$ \\
\hline Orange & $1,157,342$ & 563,046 & $10.0 \%$ \\
\hline Osceola & 273,867 & 123,236 & $11.3 \%$ \\
\hline Seminole & 424,587 & 214,254 & $9.5 \%$ \\
\hline Sumter & 96,615 & 32,999 & $8.6 \%$ \\
\hline Volusia & 495,400 & 225,622 & $10.5 \%$ \\
\hline
\end{tabular}

Sources: Employment and unemployment: http://www.bls.gov/lau/laucnty12.xls; population: http://edr.state.fl.us/Content/population-demographics/data/

The tool is applicable to each of the counties currently with urban transit services, but its applicability to Flagler or Sumter requires some special consideration:

- Availability of multipliers-neither county has had any urban transit services; RIMS II multipliers may not be available for transit O\&M spending for them. However, both counties have operated rural transit service for several years, including 2008 . The RIMS II multipliers for transit operations may be available for transit operations for these two counties if the rural transit service was picked up in RIMS II. As shown later, RIMS II multipliers for transit operations are available for Flagler County, but not for Sumter County.

- Availability of spending data-both counties have been reporting data on their rural transit service to the NTD, and the reported financial data include detailed O\&M spending by source. However, the required data for each category of capital spending are not available from the rural portion of the NTD. In terms of planned urban transit service, the planning process has not reached a stage where the planned service is well defined so that the necessary spending data for the planned service can be estimated.

As a result, the applications to District 5 will consider Flagler County for its O\&M spending on its rural transit service but will not consider Sumter County.

\section{Questions Asked}

FDOT's request came with specific questions about spending on transit and economic impacts. Table 4-3 lists these questions. Each question has been matched to a particular measure of economic impacts available in the tool. Instead of presenting results for all 
measures of impact available from the tool, this matching allows the application to focus on the most relevant results for this study request. The matched measures of impact, numbered from 1 through 6, are highlighted in Figure 4-2. Refer to Chapter 2 for details about these measures of impact.

Table 4-3. Matching Study Questions and Impact Measures

\begin{tabular}{|l|l|}
\hline Question & Impact Measure \\
\hline $\begin{array}{l}\text { 1. What does local bus service provide to the } \\
\text { community economically? }\end{array}$ & Total gross impacts of total spending \\
\hline $\begin{array}{l}\text { 2. What are the economic impacts of adding, } \\
\text { improving, or removing this service? }\end{array}$ & Total net impacts of total spending \\
\hline $\begin{array}{l}\text { 3. For every } \$ 1 \text { million invested in maintenance and } \\
\text { operations, what is the number of jobs supported? }\end{array}$ & $\begin{array}{l}\text { Unit gross impacts of total O\&M spending } \\
\text { using all funds }\end{array}$ \\
\hline $\begin{array}{l}\text { 4. For every } \$ 1 \text { million invested in capital, what is the } \\
\text { number of jobs supported? }\end{array}$ & $\begin{array}{l}\text { Unit gross impacts of total capital } \\
\text { spending using all funds }\end{array}$ \\
\hline $\begin{array}{l}\text { 5. For every } \$ 1 \text { million invested in maintenance and } \\
\text { operations, what is the number of jobs created? }\end{array}$ & $\begin{array}{l}\text { Unit net impacts of total O\&M spending } \\
\text { using all funds }\end{array}$ \\
\hline $\begin{array}{l}\text { 6. For every } \$ 1 \text { million invested in capital, what is the } \\
\text { number of jobs created? }\end{array}$ & $\begin{array}{l}\text { Unit net impacts of total capital spending } \\
\text { using all funds }\end{array}$ \\
\hline
\end{tabular}

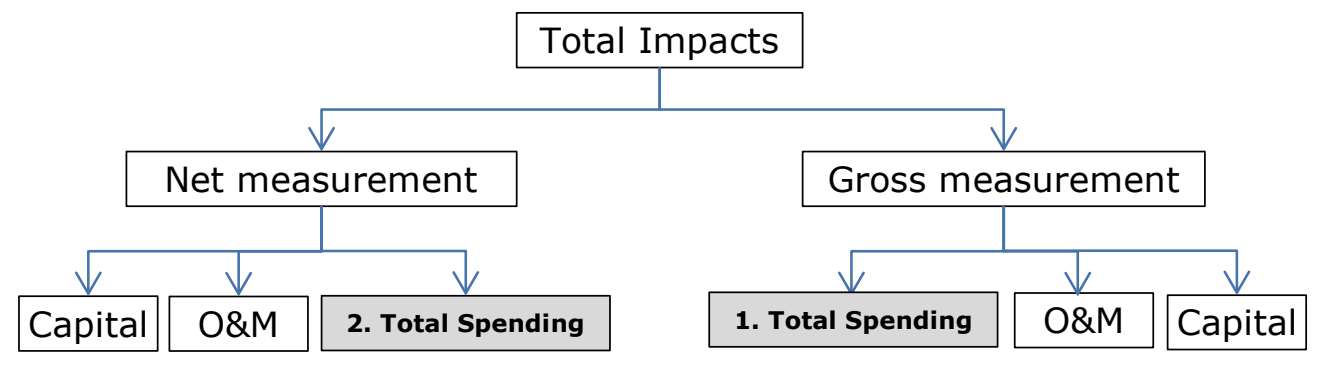

B. Matched Measures of Total Impacts

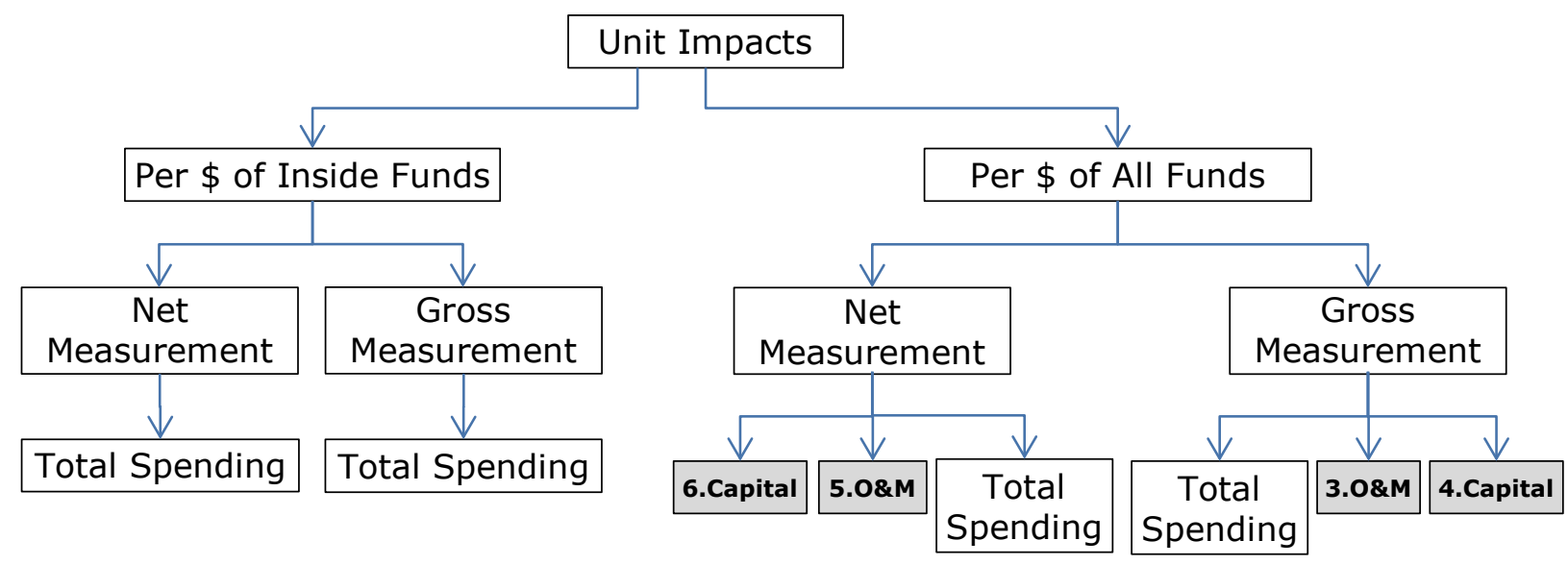

B. Matched Measures of Unit Impacts

Figure 4-2. Matched Impact Measures for Central Florida Applications 


\section{Input Data}

This section presents the required input data for each of the study counties. For each group of input data, the data are presented first. If information unique to the application is used in obtaining the input data, the source and process are also described.

No unemployment data are required for these applications because they are about existing transit services rather than service expansion. No data for the distribution of debt repayments across their sources of funds are used in these applications. There are no known borrowed funds used by any of the transit agencies for the spending on transit under consideration. Input data for the other categories are discussed below.

\section{Total O\&M Spending}

Table 4-4 shows the annual average total O\&M spending for each transit agency and each county it serves. Using the NTD to obtain data on total O\&M spending for urban transit agencies is discussed in Chapter 3 and is not repeated here.

Table 4-4. Annual Average Total O\&M Spending

\begin{tabular}{|l|l|l|}
\hline Transit Agency & County Served & Spending (2011 \$) \\
\hline \multirow{3}{*}{ LYNX Transit } & Orange & $\$ 69,568,197$ \\
\cline { 2 - 3 } & Osceola & $\$ 17,419,098$ \\
\cline { 2 - 3 } & Seminole & $\$ 10,278,350$ \\
\hline LakeXpress & Lake & $\$ 5,699,556$ \\
\hline County of Volusia dba VOTRAN & Volusia & $\$ 18,182,628$ \\
\hline Space Coast Area Transit (SCAT) & Brevard & $\$ 11,200,095$ \\
\hline SunTran & Marion & $\$ 1,885,007$ \\
\hline Flagler County Public Transportation & Flagler & $\$ 1,084,678$ \\
\hline Sumter County Transit & Sumter & $\$ 1,621,021$ \\
\hline
\end{tabular}

The following discusses unique procedures and information used for these applications:

- For SunTran, the data represent the annual average of its total spending for O\&M for 2005, 2006, and 2007. SunTran has not reported its financial data to the NTD since 2007. For other agencies and counties, the data represent the annual average of their total O\&M spending during 2009, 2010, and 2011.

- Information beyond the NTD was used to attribute the agency total for LYNX to the three counties it serves. Attributing the agency total to the counties in proportion to the amount of services provided in each county may be considered. While this makes sense for estimating the transportation benefits, it is not the most appropriate approach for estimating the economic impacts of spending on transit. For estimating the economic impacts of spending on transit, what is relevant is where the money was spent for O\&M. It is well known that the majority of the total O\&M spending is for labor; as a result, the attribution was approximated by the distribution of all LYNX employees across their county of residence. According to information provided by LYNX, about 64.3 percent of LYNX employees lived in Orange County, 16.1 
percent lived in Osceola County, 9.5 percent lived in Seminole County, and 10.1 percent lived in other counties, as of early 2013.

- The data on total O\&M spending by Flagler County Public Transportation and Sumter County Transit are from the rural portion of the NTD and are available in an Excel file named Sub-Recipient Financial Data at http://www.ntdprogram.gov/ntdprogram $\angle d a t a . h t m$. The same data are used later in determining the source of the total O\&M spending.

\section{Capital Spending by Project Category}

Table 4-5 shows the annual average capital spending for each category of capital projects for each transit agency and each county it serves. How the NTD may be used to obtain data on capital spending is discussed in Chapter 3 and is not repeated here.

Table 4-5. Annual Average Capital Spending by Project Category (2011 \$)

\begin{tabular}{|c|c|c|c|c|c|c|c|}
\hline \multirow{2}{*}{ Project Category } & \multicolumn{3}{|c|}{ LYNX Transit } & \multirow{2}{*}{\begin{tabular}{|l|} 
LakeXpress \\
Lake \\
\end{tabular}} & \multirow{2}{*}{\begin{tabular}{|l|} 
VOTRAN \\
Volusia \\
\end{tabular}} & \multirow{2}{*}{\begin{tabular}{|l|} 
SCAT \\
Brevard \\
\end{tabular}} & \multirow{2}{*}{$\begin{array}{l}\text { SunTran } \\
\text { Marion } \\
\end{array}$} \\
\hline & Orange & Osceola & Seminole & & & & \\
\hline Land Cost & $\$ 0$ & $\$ 0$ & $\$ 0$ & $\$ 0$ & $\$ 0$ & $\$ 0$ & $\$ 0$ \\
\hline Design/Engineering & $\$ 0$ & $\$ 0$ & $\$ 0$ & $\$ 0$ & $\$ 0$ & $\$ 0$ & $\$ 0$ \\
\hline Guideway & $\$ 0$ & $\$ 0$ & $\$ 0$ & $\$ 0$ & $\$ 0$ & $\$ 0$ & $\$ 0$ \\
\hline Passenger Stations & $\$ 32,386$ & $\$ 4,048$ & $\$ 4,048$ & $\$ 0$ & $\$ 95,045$ & $\$ 0$ & $\$ 0$ \\
\hline Administrative Bldgs & $\$ 339,745$ & $\$ 42,468$ & $\$ 42,468$ & $\$ 1,950$ & $\$ 244,723$ & $\$ 221,936$ & $\$ 0$ \\
\hline Maintenance Facilities & $\$ 1,312,588$ & $\$ 164,073$ & $\$ 164,073$ & $\$ 0$ & $\$ 182,447$ & $\$ 23,438$ & $\$ 178,833$ \\
\hline Other Capital Projects & $\$ 3,274,438$ & $\$ 409,305$ & $\$ 409,305$ & $\$ 14,021$ & $\$ 442,712$ & $\$ 264,263$ & $\$ 0$ \\
\hline Revenue Vehicles-Bus & $\$ 8,270,411$ & $\$ 1,033,801$ & $\$ 1,033,801$ & $\$ 1,286,124$ & $\$ 2,479,255$ & $\$ 2,140,372$ & $\$ 683,359$ \\
\hline Revenue Vehicles-Rail & $\$ 0$ & $\$ 0$ & $\$ 0$ & $\$ 0$ & $\$ 0$ & $\$ 0$ & $\$ 0$ \\
\hline Service Vehicles & $\$ 36,583$ & $\$ 4,573$ & $\$ 4,573$ & $\$ 0$ & $\$ 62,925$ & $\$ 0$ & $\$ 0$ \\
\hline \begin{tabular}{|l} 
Fare \\
Collection Systems
\end{tabular} & $\$ 6,488$ & $\$ 811$ & $\$ 811$ & $\$ 0$ & $\$ 0$ & $\$ 3,717$ & $\$ 0$ \\
\hline $\begin{array}{l}\text { Communications/ } \\
\text { Information Systems }\end{array}$ & $\$ 1,269,204$ & $\$ 158,650$ & $\$ 158,650$ & $\$ 22,371$ & $\$ 28,586$ & $\$ 287,934$ & $\$ 0$ \\
\hline
\end{tabular}

The following discusses unique procedures and information used for these applications:

- For SunTran, the data represent the annual average of its capital spending for 2005 and 2007. SunTran has not reported its financial data to the NTD since 2007 and did not report its capital expenses for 2006. For other agencies and counties, the data represent the annual average of their capital spending during 2009, 2010, and 2011.

- Information beyond the NTD was used to attribute the LYNX total to the three counties it serves. Ideally, this attribution should be for each category of capital spending separately. In addition, this attribution should be based on where each capital project occurred. Without such detailed information, however, this project used the following distribution for every project category: 80 percent to Orange, 10 percent to Osceola, and 10 percent to Seminole. This distribution roughly represents the number of LYNX bus routes operated in each county.

- Data are not readily-available on whether the spending for each construction category included any land cost or how much the land cost was. As a result, Land 
Cost as a separate category is zero for all study counties. In addition, the land cost, if any, would be included in each category of construction projects. One consequence of not separating land cost from the spending for any construction project is somewhat inflated estimates of impacts.

- Similarly, data are not readily-available on the cost for design and engineering services. As a result, Design/Engineering as a separate category is zero for all study counties. In addition, the cost for design and engineering services, if any, would be included in each category of construction projects. How not separating the cost for design and engineering from the spending for any construction project affects the estimated impacts depends on each particular application. At least for the current applications, this simplifying procedure most likely would understate the true impacts. For almost all of these counties, the multipliers for any given impact type (output, value added, etc.) are greater for design and engineering than for construction.

- Capital spending for Flagler County Public Transportation and Sumter County Transit was not considered; their capital spending is reported to the NTD, but the reported data are not broken down for each capital category.

\section{Distribution of Spending across its Source of Funds}

Table 4-6 shows the distribution across the sources of funds for annual average total capital spending and annual average total O\&M spending for each county. Using the NTD to obtain spending data by their source for urban transit services is discussed in Chapter 3 and is not repeated here.

Table 4-6. Distribution of Total Spending across Its Sources

\begin{tabular}{|c|c|c|c|c|}
\hline \multirow[b]{2}{*}{ County } & \multicolumn{2}{|l|}{ O\&M } & \multicolumn{2}{|l|}{ Capital } \\
\hline & $\begin{array}{l}\text { Outside } \\
\text { Study Area }\end{array}$ & $\begin{array}{l}\text { Inside } \\
\text { Study Area }\end{array}$ & $\begin{array}{l}\text { Outside } \\
\text { Study Area }\end{array}$ & $\begin{array}{l}\text { Inside } \\
\text { Study Area }\end{array}$ \\
\hline Orange & $32.2 \%$ & $67.8 \%$ & $95.3 \%$ & $4.7 \%$ \\
\hline Osceola & $32.2 \%$ & $67.8 \%$ & $95.3 \%$ & $4.7 \%$ \\
\hline Seminole & $32.2 \%$ & $67.8 \%$ & $95.3 \%$ & $4.7 \%$ \\
\hline Lake & $75.5 \%$ & $24.5 \%$ & $96.7 \%$ & $3.3 \%$ \\
\hline Volusia & $35.8 \%$ & $64.2 \%$ & $100.0 \%$ & $0.0 \%$ \\
\hline Brevard & $63.1 \%$ & $36.9 \%$ & $100.0 \%$ & $0.0 \%$ \\
\hline Marion & $68.7 \%$ & $31.3 \%$ & $96.0 \%$ & $4.0 \%$ \\
\hline Flagler & $51.8 \%$ & $48.2 \%$ & $\mathrm{~N} / \mathrm{A}$ & $\mathrm{N} / \mathrm{A}$ \\
\hline Sumter & $43.8 \%$ & $56.2 \%$ & $\mathrm{~N} / \mathrm{A}$ & N/A \\
\hline
\end{tabular}

The following discusses unique procedures and information used for these applications:

- For SunTran, the data represent again the annual average of its capital spending for 2005 and 2007. For other agencies and counties, the data represent the annual average conditions during 2009, 2010, and 2011.

- The LYNX distributions derived from NTD data are used for each of the service counties. This is a reasonable procedure for total spending of each spending type (capital vs. O\&M). 
- Ideally, the distribution for capital spending should be unique to each category of capital projects. The funds for some capital projects are more likely to come from outside the study area than for other capital projects. For these applications, however, the distribution for total capital spending is used for every category. The effect of this simplifying procedure again depends on the particular circumstances. In general, the aggregated effect of this simplifying procedure is likely to be negligible because the overall distribution is close to the distributions for the categories with the largest amount of spending.

- For Flagler and Sumter counties, the distribution for total O\&M spending was derived from the same Excel file as the data for total O\&M spending described earlier.

\section{Distribution of Spending across Destinations of Spending}

Table 4-7 shows the distribution of spending made inside and outside the study area for total O\&M spending and for each relevant category of capital projects.

Table 4-7. Distribution of Spending Across Destinations of Spending

\begin{tabular}{|l|l|l|l|}
\hline $\begin{array}{l}\text { Type of } \\
\text { Spending }\end{array}$ & Category of Spending & $\begin{array}{l}\text { Outside } \\
\text { Study Area }\end{array}$ & $\begin{array}{l}\text { Inside } \\
\text { Study Area }\end{array}$ \\
\hline O\&M & Total & $10 \%$ & $90 \%$ \\
\hline \multirow{5}{*}{ Capital } & Passenger Stations & $0 \%$ & $100 \%$ \\
\cline { 2 - 4 } & Administrative Buildings & $0 \%$ & $100 \%$ \\
\cline { 2 - 4 } & Maintenance Facilities & $25 \%$ & $75 \%$ \\
\cline { 2 - 4 } & Other Capital Projects & $0 \%$ & $100 \%$ \\
\cline { 2 - 4 } & Revenue Vehicles - Bus & $100 \%$ & $0 \%$ \\
\cline { 2 - 4 } & Service Vehicles & $100 \%$ & $0 \%$ \\
\cline { 2 - 4 } & Fare Revenue Collection Systems & $100 \%$ & $0 \%$ \\
\cline { 2 - 4 } & Communications \& Information Systems & $100 \%$ & $0 \%$ \\
\hline
\end{tabular}

Without detailed agency records on exactly where each product or service was purchased, it was assumed that these distributions were made on the basis of general knowledge of agency purchasing practices:

- In most cases, the majority of total O\&M spending is made inside the study area. It is assumed for these applications that the study area captures 90 percent of total O\&M spending, which represents the share of LYNX employees living in its three service counties. For the other transit agencies, this percentage is likely to be somewhat smaller.

- Most of the spending for construction-related capital projects is likely made mostly inside the study area.

- All spending for purchasing vehicles, fare collection systems, or communications and information systems is assumed to be made outside each study county. For the majority of study areas, this is likely to be the case.

- The same distributions are used for all study counties in these applications. In general, the smaller a study area, the greater share of spending is made outside the 
study area. As a result, using the distribution for LYNX to all other agencies is likely to inflate the estimated impacts somewhat for those other counties.

- This distribution is not needed and is not shown for capital categories with zero spending in Table 4-5.

\section{Type II Multipliers}

Table 4-8 shows the multipliers used in these applications. How one may obtain such RIMS II multipliers is discussed in Chapter 3 and not repeated here. The multipliers are shown only for three of the total eight RIMS II industries considered in the tool. These applications do not need the multipliers for the other five industries for one of the following reasons:

Table 4-8. Type II Multipliers from RIMS II

\begin{tabular}{|l|l|l|l|l|l|}
\hline RIMS II Industries & County & Output & Earnings & Employment & Value Added \\
\hline \multirow{4}{*}{$\begin{array}{l}\text { Construction } \\
\text { (230000 in Table 1.5) }\end{array}$} & Orange & 1.7798 & 0.3953 & 10.5463 & 0.9664 \\
\cline { 2 - 6 } & Osceola & 1.4413 & 0.3155 & 8.4754 & 0.7671 \\
\cline { 2 - 6 } & Seminole & 1.6835 & 0.3383 & 9.0224 & 0.9067 \\
\cline { 2 - 6 } & Lake & 1.5361 & 0.3911 & 10.5612 & 0.8081 \\
\cline { 2 - 6 } & Volusia & 1.6885 & 0.5313 & 14.5022 & 0.9069 \\
\cline { 2 - 6 } & Brevard & 1.6726 & 0.5511 & 14.8401 & 0.8998 \\
\cline { 2 - 6 } & Marion & 1.7039 & 0.5343 & 14.4306 & 0.9096 \\
\cline { 2 - 6 } & Flagler & 1.4099 & 0.4071 & 11.1168 & 0.7503 \\
\cline { 2 - 6 } & Sumter & 1.3501 & 0.2907 & 7.7716 & 0.6923 \\
\hline \hline \multirow{4}{*}{$\begin{array}{l}\text { Passenger } \\
\text { (485A00, Table 1.5) }\end{array}$} & Orange & 1.8658 & 0.4079 & 15.1392 & 0.8494 \\
\cline { 2 - 6 } & Osceola & 1.4098 & 0.2730 & 10.9550 & 0.5715 \\
\cline { 2 - 6 } & Seminole & 1.7200 & 0.3338 & 12.4300 & 0.7647 \\
\cline { 2 - 6 } & Lake & 1.3743 & 0.2448 & 9.6961 & 0.5462 \\
\cline { 2 - 6 } & Volusia & 1.6647 & 0.4824 & 18.8848 & 0.7151 \\
\cline { 2 - 6 } & Brevard & 1.6023 & 0.4925 & 19.2121 & 0.6885 \\
\cline { 2 - 6 } & Marion & 1.5979 & 0.4811 & 19.0602 & 0.6842 \\
\cline { 2 - 6 } & Flagler & 1.3033 & 0.2671 & 10.8790 & 0.5089 \\
\cline { 2 - 6 } & Sumter & 1.0000 & 0.0000 & 0.0000 & 0.0000 \\
\hline \hline \multirow{4}{*}{$\begin{array}{l}\text { Households } \\
\text { (H00000, Table 1.5) }\end{array}$} & Orange & 1.0816 & 0.2165 & 6.6058 & 0.6727 \\
\cline { 2 - 6 } & Osceola & 0.7522 & 0.1358 & 4.3965 & 0.4792 \\
\cline { 2 - 6 } & Seminole & 0.9458 & 0.1774 & 5.4199 & 0.5969 \\
\cline { 2 - 6 } & Lake & 0.7288 & 0.1510 & 4.9398 & 0.4595 \\
\cline { 2 - 6 } & Volusia & 0.8771 & 0.2318 & 7.4834 & 0.5538 \\
\cline { 2 - 6 } & Brevard & 0.7817 & 0.2195 & 6.9841 & 0.4927 \\
\cline { 2 - 5 } & Marion & 0.8286 & 0.2157 & 6.8255 & 0.5228 \\
\cline { 2 - 5 } & Flagler & 0.6272 & 0.1384 & 4.8052 & 0.4045 \\
\cline { 2 - 4 } & Sumter & 0.4646 & 0.0865 & 2.9776 & 0.2930 \\
\hline
\end{tabular}

- There is no spending related to an industry. For example, spending on design and engineering is assumed to be zero for every study county, and the related industry for design and engineering is Professional, Scientific, and Technical Services (RIMS II industry code 48 in Table 2.5).

- There is no spending inside the study area for an industry. For example, spending on vehicles, fare collection systems, and communications and information systems is assumed to be made entirely outside the study areas. Money spent outside the study area does not support or create any economic activity in the study area. 
As discussed previously, a critical multiplier for these applications is for the RIMS II industry of Transit and Ground Passenger Transportation. It is available for Flagler County but not for Sumter County, as indicated by the 1 for output and 0 for other impact types.

\section{Summary of Spending}

Table 4-9 summarizes the spending data used for these applications. To help better understand the results on estimated impacts later, the table also indicates the qualitative effect of spending for each combination of fund source and spending destination on net impacts and gross impacts. 
Table 4-9. Summary of Average Annual Spending

\begin{tabular}{|c|c|c|c|c|c|c|c|c|c|c|c|}
\hline \multirow{3}{*}{\multicolumn{2}{|c|}{\begin{tabular}{|l|} 
Source of Funds \\
Destination of Spending
\end{tabular}}} & \multicolumn{5}{|c|}{ Amount of Spending (millions, 2011 \$) } & \multicolumn{5}{|c|}{ Distribution of Spending } \\
\hline & & \multicolumn{2}{|c|}{$\begin{array}{l}\text { Outside Study } \\
\text { Area }\end{array}$} & \multicolumn{2}{|c|}{$\begin{array}{l}\text { Inside Study } \\
\text { Area }\end{array}$} & \multirow{4}{*}{ Total } & \multicolumn{2}{|c|}{$\begin{array}{l}\text { Outside Study } \\
\text { Area }\end{array}$} & \multicolumn{2}{|c|}{$\begin{array}{l}\text { Inside Study } \\
\text { Area }\end{array}$} & \multirow{4}{*}{ Total } \\
\hline & & $\begin{array}{l}\text { Inside } \\
\text { Study } \\
\text { Area }\end{array}$ & \begin{tabular}{|l|} 
Outside \\
Study \\
Area \\
\end{tabular} & $\begin{array}{l}\text { Inside } \\
\text { Study } \\
\text { Area }\end{array}$ & $\begin{array}{l}\text { Outside } \\
\text { Study } \\
\text { Area }\end{array}$ & & $\begin{array}{l}\text { Inside } \\
\text { Study } \\
\text { Area }\end{array}$ & $\begin{array}{l}\text { Outside } \\
\text { Study } \\
\text { Area }\end{array}$ & $\begin{array}{l}\text { Inside } \\
\text { Study } \\
\text { Area }\end{array}$ & $\begin{array}{l}\text { Outside } \\
\text { Study } \\
\text { Area }\end{array}$ & \\
\hline \multicolumn{2}{|c|}{ Effect on Net Impacts } & + & 0 & 0 & - & & + & 0 & 0 & - & \\
\hline \multicolumn{2}{|c|}{ Effect on Gross Impacts } & + & 0 & + & - & & + & 0 & + & - & \\
\hline \multirow{8}{*}{ 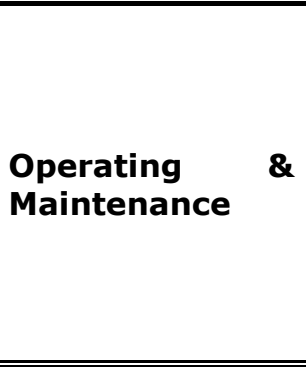 } & Brevard & $\$ 6.36$ & $\$ 0.71$ & $\$ 3.72$ & $\$ 0.41$ & $\$ 11.20$ & $56.8 \%$ & $6.3 \%$ & $33.2 \%$ & $3.7 \%$ & $100 \%$ \\
\hline & Flagler & $\$ 0.39$ & $\$ 0.17$ & $\$ 0.37$ & $\$ 0.16$ & $\$ 1.08$ & $36.3 \%$ & $15.6 \%$ & $33.7 \%$ & $14.4 \%$ & $100 \%$ \\
\hline & Lake & $\$ 3.87$ & $\$ 0.43$ & $\$ 1.26$ & $\$ 0.14$ & $\$ 5.70$ & $67.9 \%$ & $7.5 \%$ & $22.1 \%$ & $2.5 \%$ & $100 \%$ \\
\hline & Marion & $\$ 1.17$ & $\$ 0.13$ & $\$ 0.53$ & $\$ 0.06$ & $\$ 1.89$ & $61.9 \%$ & $6.9 \%$ & $28.1 \%$ & $3.1 \%$ & $100 \%$ \\
\hline & Orange & $\$ 20.16$ & $\$ 2.24$ & $\$ 42.45$ & $\$ 4.72$ & $\$ 69.57$ & $29.0 \%$ & $3.2 \%$ & $61.0 \%$ & $6.8 \%$ & $100 \%$ \\
\hline & Osceola & $\$ 5.05$ & $\$ 0.56$ & $\$ 10.63$ & $\$ 1.18$ & $\$ 17.42$ & $29.0 \%$ & $3.2 \%$ & $61.0 \%$ & $6.8 \%$ & $100 \%$ \\
\hline & Seminole & $\$ 2.98$ & $\$ 0.33$ & $\$ 6.27$ & $\$ 0.70$ & $\$ 10.28$ & $29.0 \%$ & $3.2 \%$ & $61.0 \%$ & $6.8 \%$ & $100 \%$ \\
\hline & Volusia & $\$ 5.86$ & $\$ 0.65$ & $\$ 10.51$ & $\$ 1.17$ & $\$ 18.18$ & $32.2 \%$ & $3.6 \%$ & $57.8 \%$ & $6.4 \%$ & $100 \%$ \\
\hline \multirow{8}{*}{ Capital } & Brevard & $\$ 0.50$ & & $\$ 0.00$ & 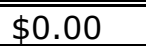 & $\$ 2.94$ & $17.1 \%$ & $9 \%$ & $\%$ & $0.0 \%$ & $100 \%$ \\
\hline & $\mathrm{Fla}$ & & & & & & & & & & \\
\hline & Lake & $\$ 0.02$ & $\$ 1.27$ & $\$ 0.00$ & $\$ 0.00$ & $\$ 1.28$ & $1.2 \%$ & $98.7 \%$ & $0.0 \%$ & $0.1 \%$ & $100 \%$ \\
\hline & Marion & $\$ 0.13$ & $\$ 0.70$ & $\$ 0.01$ & $\$ 0.00$ & $\$ 0.83$ & $15.4 \%$ & $83.7 \%$ & $0.6 \%$ & $0.2 \%$ & $100 \%$ \\
\hline & Orange & $\$ 4.41$ & $\$ 9.44$ & $\$ 0.22$ & $\$ 0.08$ & $\$ 14.15$ & $31.2 \%$ & $66.7 \%$ & $1.6 \%$ & $0.5 \%$ & $100 \%$ \\
\hline & Osceola & $\$ 0.55$ & $\$ 1.18$ & $\$ 0.03$ & $\$ 0.01$ & $\$ 1.77$ & $31.2 \%$ & $66.7 \%$ & $1.6 \%$ & $0.5 \%$ & $100 \%$ \\
\hline & Seminole & $\$ 0.55$ & $\$ 1.18$ & $\$ 0.03$ & $\$ 0.01$ & $\$ 1.77$ & $31.2 \%$ & $66.7 \%$ & $1.6 \%$ & $0.5 \%$ & $100 \%$ \\
\hline & Volusia & $\$ 0.92$ & & $\$ 0.00$ & $\$ 0.00$ & $\$ 3.54$ & $26.0 \%$ & $74.0 \%$ & $0.0 \%$ & $0.0 \%$ & $100 \%$ \\
\hline \multirow{8}{*}{ Total Spending } & Brev & $\$ \$ 6.86$ & & & & $\$ 14.14$ & $48.5 \%$ & $22.2 \%$ & $26.3 \%$ & $2.9 \%$ & $100 \%$ \\
\hline & Flagler & $\$ 0.39$ & & $\$ 0.37$ & & $\$ 1.08$ & $36.3 \%$ & & $33.7 \%$ & & $100 \%$ \\
\hline & Lake & $\$ 3.89$ & $\$ 1.70$ & $\$ 1.26$ & $\$ 0$. & $\$ 6.98$ & $55.7 \%$ & & $18.0 \%$ & $2.0 \%$ & $100 \%$ \\
\hline & Marion & $\$ 1.30$ & $\$ 0.83$ & $\$ 0.54$ & $\$ 0.06$ & $\$ 2.72$ & $47.6 \%$ & $30.5 \%$ & $19.7 \%$ & $2.2 \%$ & $100 \%$ \\
\hline & Orange & $\$ 24.57$ & $\$ 11.68$ & $\$ 42.67$ & $\$ 4.79$ & $\$ 83.72$ & $29.4 \%$ & $14.0 \%$ & $51.0 \%$ & $5.7 \%$ & $100 \%$ \\
\hline & Osceola & $\$ 5.60$ & $\$ 1.74$ & $\$ 10.66$ & $\$ 1.19$ & $\$ 19.19$ & $29.2 \%$ & $9.1 \%$ & $55.5 \%$ & $6.2 \%$ & $100 \%$ \\
\hline & Seminole & $\$ 3.53$ & $\$ 1.51$ & $\$ 6.30$ & $\$ 0.71$ & $\$ 12.05$ & $29.3 \%$ & $12.5 \%$ & $52.3 \%$ & $5.9 \%$ & $100 \%$ \\
\hline & Volusia & $\$ 6.77$ & $\$ 3.27$ & $\$ 10.51$ & $\$ 1.17$ & $\$ 21.72$ & $31.2 \%$ & $15.0 \%$ & $48.4 \%$ & $5.4 \%$ & $100 \%$ \\
\hline
\end{tabular}




\section{Estimates of Total Impacts}

Two of the questions raised by District 5 relate to the absolute size of the economic impacts of spending on transit. To answer these questions, results for two measures of total impacts are reported here: 1 ) total gross impacts of total spending and 2) total net impacts of total spending. Both measures show the economic impacts of all spending on transit, including both O\&M and capital. These two measures differ in that spending local funds outside the study area has zero net impacts but has positive gross impacts.

\section{Total Gross Impacts of Total Spending}

Table 4-10 presents the estimated total gross impacts of total spending for providing all public transit service on an annual basis for each study county. These results can help answer the question, what does local transit service provide to the community economically? Or, asked differently, how much of the local economy is supported by the annual spending on transit in the community?

Table 4-10. Total Gross Impacts of Total Spending

\begin{tabular}{|l|l|l|l|l|}
\hline County & $\begin{array}{l}\text { Output } \\
\text { (millions, } \\
\mathbf{2 0 1 1} \$ \mathbf{)}\end{array}$ & $\begin{array}{l}\text { Value Added } \\
\text { (millions, } \\
\mathbf{2 0 1 1} \mathbf{\$})\end{array}$ & $\begin{array}{l}\text { Earnings } \\
\text { (millions, } \\
\mathbf{2 0 1 1} \mathbf{\text { J }}\end{array}$ & $\begin{array}{l}\text { Jobs } \\
\text { (person- } \\
\text { years) }\end{array}$ \\
\hline Brevard & $\$ 16.99$ & $\$ 7.39$ & $\$ 5.24$ & 201 \\
\hline Flagler & $\$ 0.99$ & $\$ 0.39$ & $\$ 0.20$ & 8 \\
\hline Lake & $\$ 7.07$ & $\$ 2.81$ & $\$ 1.26$ & 50 \\
\hline Marion & $\$ 2.94$ & $\$ 1.28$ & $\$ 0.89$ & 34 \\
\hline Orange & $\$ 125.06$ & $\$ 57.66$ & $\$ 27.37$ & 997 \\
\hline Osceola & $\$ 22.94$ & $\$ 9.40$ & $\$ 4.46$ & 177 \\
\hline Seminole & $\$ 16.89$ & $\$ 7.60$ & $\$ 3.28$ & 120 \\
\hline Volusia & $\$ 28.79$ & $\$ 12.54$ & $\$ 8.38$ & 322 \\
\hline
\end{tabular}

Consider Brevard County as an example. According to Table 4-9, a total of $\$ 14.14$ million is spent annually on providing urban transit services in the county. Some of this total spending does not provide support to the local economy, including the $\$ 3.14$ million spent outside the county using funds from outside the county. In addition, a small portion of this total spending has a draining effect on the local economy, including the $\$ 0.41$ million spent outside the county using funds from inside the county. As a result, a net amount of only $\$ 10.17$ million ( $=\$ 6.86+\$ 3.72-\$ 0.41$ ) actually supports the local economy. Specifically, the amount of economic activities supported by this spending includes $\$ 16.99$ million in total sales, \$7.39 million in value added, \$5.24 million in labor earnings, and 201 person-years of full- and part-time employment. SCAT, the transit agency serving Brevard, had 112 fulland part-time employees during its fiscal year 2011 as reported to the NTD.

\section{Total Net Impacts of Total Spending}

Table 4-11 presents the estimated total net impacts of total spending for providing all public transit service on an annual basis for each study county. These results can help answer the question, what is the economic impact of removing the transit service? Or, asked 
differently, how much of the local economy is generated by the annual spending on transit in the community?

Table 4-11. Total Net Impacts of Total Spending

\begin{tabular}{|l|l|l|l|l|}
\hline County & $\begin{array}{l}\text { Output } \\
\text { (millions, } \\
\mathbf{2 0 1 1} \$ \text { ) }\end{array}$ & $\begin{array}{l}\text { Value Added } \\
\text { (millions, } \\
\mathbf{2 0 1 1} \$ \text { ) }\end{array}$ & $\begin{array}{l}\text { Earnings } \\
\text { (millions, } \\
\mathbf{2 0 1 1} \$ \text { ) }\end{array}$ & $\begin{array}{l}\text { Jobs } \\
\text { (person- } \\
\text { years) }\end{array}$ \\
\hline Brevard & $\$ 10.71$ & $\$ 4.63$ & $\$ 3.32$ & 127 \\
\hline Flagler & $\$ 0.41$ & $\$ 0.14$ & $\$ 0.08$ & 4 \\
\hline Lake & $\$ 5.24$ & $\$ 2.06$ & $\$ 0.93$ & 37 \\
\hline Marion & $\$ 2.03$ & $\$ 0.88$ & $\$ 0.62$ & 24 \\
\hline Orange & $\$ 40.28$ & $\$ 18.16$ & $\$ 8.93$ & 320 \\
\hline Osceola & $\$ 7.02$ & $\$ 2.74$ & $\$ 1.39$ & 55 \\
\hline Seminole & $\$ 5.38$ & $\$ 2.36$ & $\$ 1.06$ & 38 \\
\hline Volusia & $\$ 10.28$ & $\$ 4.37$ & $\$ 3.04$ & 115 \\
\hline
\end{tabular}

Continuing with the above example for Brevard County, although the net amount of $\$ 10.17$ million provides support to the local economy, $\$ 3.72$ million of it is spent inside the county using money from the county and, hence, does not create any new economy activity. As a result, a net amount of only $\$ 6.45$ million actually creates new economic activities in the county, including $\$ 10.71$ million in output (total sales), $\$ 4.63$ million in value added, $\$ 3.32$ million in labor earnings, and 127 person-years of full- and part-time employment.

\section{Estimates of Unit Impacts}

As mentioned earlier, unit impacts may be measured as total impacts per unit of spending of all funds or as total impacts per unit of spending of only local funds. The numerator is the same with these two measurements; they differ in the denominator-one is spending from all resources and the other is spending from local resources. The unit impacts measured relative to local resources may be more relevant for local communities. As discussed in Chapter 2, local resources include not only revenues from local governments but also revenues the transit agency directly generates and revenues from taxes dedicated to transit.

\section{Unit Impacts Relative to Spending of All Funds}

Four of the questions raised by District 5 relate to the relative size of the economic impacts of spending on transit. To answer these rate-of-return questions, results for four measures of unit impacts are reported here:

1. Unit gross impacts on jobs per $\$ 1$ million O\&M spending of all funds

2. Unit gross impacts on jobs per $\$ 1$ million capital spending of all funds

3. Unit net impacts on jobs per $\$ 1$ million O\&M spending of all funds

4. Unit net impacts on jobs per $\$ 1$ million capital spending of all funds 
These measures differ in whether the impacts are net or gross and whether it is O\&M or capital spending. Table 4-12 presents the results for these four impact measures.

To answer the four rate-of-return questions, Brevard County is again used as an example for illustration:

- For every $\$ 1$ million invested in transit O\&M, what is the number of jobs supported? Every $\$ 1$ million of all funds invested in O\&M in Brevard County supports 17.3 jobs annually in the local economy.

- For every $\$ 1$ million invested in capital, what is the number of jobs supported? Every $\$ 1$ million of all funds invested in capital projects in Brevard County supports 2.5 jobs annually in the local economy.

- For every $\$ 1$ million invested in transit O\&M, what is the number of jobs created? Every $\$ 1$ million of all funds invested in O\&M in Brevard County creates 10.6 jobs annually in the local economy.

- For every $\$ 1$ million invested in capital, what is the number of jobs created? Every $\$ 1$ million of all funds invested in capital in Brevard County creates 2.5 jobs annually.

One observation from these answers is that the net and gross unit impacts differ significantly for O\&M spending but are similar for capital spending. The summary data in Table 4-9 can provide an explanation. The key is the proportion of the spending that uses local resources and is spent locally. This portion of the spending supports a certain number of jobs but does not generate jobs. This proportion for Brevard is about one-third for O\&M spending and zero for capital spending.

Another interesting observation is that the rate-of-return is much higher for O\&M spending than for capital spending. The reason is not because O\&M spending is more productive in supporting or creating jobs than capital spending. Rather, this is because O\&M spending and capital spending differ dramatically in where the funds come from and where they are spent. Take net impacts as an example. The most important determining factor for net impacts is the proportion of spending that uses outside funds but is spent locally. According to Table 4-9, this proportion for Brevard is 56.8 percent for O\&M spending but is only 17.1 percent for capital spending.

One obvious pattern in these results of unit impacts of O\&M spending on jobs is that they differ significantly across the counties. These differences result largely from two factors: differences in the multipliers and differences in where the funds come from and where they are spent. Compare the unit net impacts between Brevard and Osceola counties as an example:

- Multipliers - the most relevant multipliers for job impacts of O\&M spending are those for the RIMS II industry of Transit and Ground Passenger Transportation. As shown in Table 4-8, the job multiplier is 19.2121 for Brevard and 10.9550 for Osceola, almost a 2-to-1 ratio.

- Patterns of Funding and Spending-as stated earlier, the most important determining factor for net impacts is the proportion of spending that uses outside funds but is 
spent locally. This proportion is 56.8 percent for Brevard but is only 29.0 percent for Osceola.

Both factors are significantly more favorable toward Brevard in creating jobs with spending on public transit in the local economy.

\section{Unit Impacts Relative to Spending of Local Funds}

Table 4-13 reports both gross and net unit job impacts of total spending for every $\$ 1$ million of local funds spent on transit. Flagler County is not included because its capital spending is not considered. The following are two notable observations:

Table 4-12. Unit Impacts on Jobs per $\$ 1$ Million of All Funds

\begin{tabular}{|l|l|l|l|l|}
\hline \multirow{2}{*}{ County } & Unit Gross Impacts & \multicolumn{2}{l|}{ Unit Net Impacts } \\
\cline { 2 - 5 } & O\&M & Capital & O\&M & Capital \\
\hline Brevard & 17.3 & 2.5 & 10.6 & 2.5 \\
\hline Flagler & 7.6 & $\mathrm{~N} / \mathrm{A}$ & 3.3 & $\mathrm{~N} / \mathrm{A}$ \\
\hline Lake & 8.7 & 0.1 & 6.5 & 0.1 \\
\hline Marion & 17.2 & 2.2 & 11.6 & 2.1 \\
\hline Orange & 13.6 & 3.4 & 3.9 & 3.2 \\
\hline Osceola & 9.9 & 2.7 & 2.9 & 2.5 \\
\hline Seminole & 11.2 & 2.9 & 3.2 & 2.7 \\
\hline Volusia & 17.0 & 3.8 & 5.6 & 3.8 \\
\hline
\end{tabular}

Table 4-13. Unit Impacts of Total Spending on Jobs per $\$ 1$ Million of Local Funds

\begin{tabular}{|l|l|l|}
\hline County & Gross & Net \\
\hline Brevard & 48.6 & 30.6 \\
\hline Lake & 25.7 & 34.6 \\
\hline Marion & 54.9 & 38.0 \\
\hline Orange & 20.8 & 6.7 \\
\hline Osceola & 14.8 & 4.6 \\
\hline Seminole & 17.0 & 5.4 \\
\hline Volusia & 27.6 & 9.9 \\
\hline
\end{tabular}

- These values are significantly greater than those measured relative to all funds. This is the result of a simple math: the denominator is smaller, with measurement being relative to all funds than relative to local funds only. Consider Brevard again: its annual average spending from all sources is $\$ 14.14$ million, but only $\$ 4.14$ million uses local resources. While being the result of simple math, the significantly greater values of unit impacts are meaningful. Instead of creating only 10 jobs annually for every $\$ 1$ million of all resources spent on transit services, every $\$ 1$ million of local resources spent on transit services creates 30 jobs annually in the county.

- The patterns of relative differences across counties differ between the unit impacts relative to all funds versus the unit impacts measured relative to only local funds. This change in patterns results largely from differences across the counties in their 
share of total spending on transit using local resources. According to Table 4-9, this share is $26.3+2.9=29.2$ percent for Brevard and $55.5+6.2=61.7$ percent for Osceola. This difference between these two counties in their local share of total spending on transit makes their unit impacts measured relative to local funds differ even more than their unit impacts measured relative to all funds.

\section{A Caution for Interpretation}

The estimated impacts reported above represent the economic impacts that likely have resulted from not only the amount of annual spending but also the pattern of its funding source and the spending destinations. For a given county, the economic impacts of the same amount of spending could be significantly different if the pattern of its funding source and the spending destinations differ from those implicit in the results presented here. For example, users of this tool should not try to estimate the economic impacts of future spending on transit from the economic impacts reported above. Instead, this tool should be applied separately to future spending on transit to re-estimate the likely economic impacts.

\section{Future Applicability to Central Florida}

The tool's applicability to the individual counties in Central Florida is already discussed earlier in relation to the availability of required data. Specifically:

- The tool was not applied to Sumter County because the latest RIMS II multipliers for the county do not capture its rural transit service.

- For Flagler County, the rural portion of the NTD contains data on the annual total O\&M spending but on the annual capital spending of its rural transit service for the pre-specified categories. As a result, the tool was applied to Flagler County for its O\&M spending but not its capital spending.

- The current applications of the tool to Central Florida relied primarily on NTD for spending data. For the SunRail service being developed, data on its capital spending are not readily available. In addition, the latest RIMS II multipliers of capital spending for each county served by LYNX may not be adequate for estimating the economic impacts of spending for constructing SunRail.

The tool's future applicability to Central Florida may improve, however. Both Sumter County and Flagler County are planning urban transit service. RIMS II multipliers will be able to capture these new services in a few years after they have started. In addition, good data on the capital spending for developing SunRail may become available. A peer study area may be identified and whose RIMS II multipliers may be borrowed to estimate the economic impacts of the capital spending. Further into the future, the tool can also be used to estimate the economic impact of the on-going capital and O\&M spending by SunRail on the local economies served by SunRail. 


\section{Chapter 5 - Conclusions}

This project developed an Excel-based template for transit agencies, local governments, and other stakeholders of public transit to estimate the economic impacts of spending on public transit with the following main design features:

1. It is built on a commonly-used method for impact assessment of public spending. This basic method requires industry-specific multipliers that capture the full ripple effects of spending on transit in terms of four measures of economic activity-gross output (sales), value added (regional GDP), labor earnings, and jobs (person-years of both full and part-time employment)-for any study area consisting of one or more spatially-contiguous counties. The required multipliers should be purchased on a user-by-user basis from the U.S. Bureau of Economic Analysis. The estimated impacts from this tool are for all industries affected by the spending on transit.

2. It reflects the professional best practices for implementing this basic method. These best practices require data not only on the components of spending in terms of capital vs. operations and maintenance (O\&M) and different categories of capital projects but also on the patterns of spending in terms of where the money is spent, where the money comes from, whether the money is borrowed, etc. Most of the required spending data can be derived from the National Transit Database for existing services. All of the required spending data will need to be estimated for service expansion or new services.

3. It is flexible and provides a range of options to meet the information needs that vary across communities and for different purposes within a community. For example, it presents the results separately for capital projects, O\&M, and total spending; and presents the results in terms of both total impacts and unit impacts per dollar spent. Furthermore, it provides estimates of net economic impacts that may be considered as being created by the spending on transit and would not exist without the public transit service and related spending. As an option, it also provides estimates of gross economic impacts, which may be considered as being supported by the spending on transit.

4. It is simple, easy to use, and requires minimum input data necessary for the first three design features.

To minimize data requirements, the tool makes several simplifying assumptions on how the various factors considered influence the estimated economic impacts. For examples:

- Non-land spending inside the study area has zero net impact if borrowed funds were used and debt repayments in the future would be made with local resources. While the spending supports a certain amount of economic activities now, the debt repayments will have a negative effect on the economy in the future. The underlying assumption is that the debt repayments, including both interest and principle, would be roughly the same in present-day dollars as the borrowed funds. 
- Spending local resources in the study area has zero net impacts. The assumption is that the expended funds from inside the study area would support approximately the same amount of economic activities as the actual spending on transit.

- Spending on transit on service expansion in a study area with an unemployment rate 4.8 percent or lower creates no new jobs in the study area even if funds from outside the study area are spent inside the study area.

- Spending local resources on products and services made outside the study area has negative net impacts.

The tool is applicable to any given set of spending on transit as long as the required data are available either from observation or estimation and the application is proper relative to the limitations of the multipliers used. It is primarily designed for estimating the economic impacts of spending on transit on existing service or on service expansion in an area that already has transit service. It also is applicable with extreme caution to new transit services with borrowed values for the required multipliers from peer areas that do have existing transit service. Therefore this tool does not preclude it from being applied to any specific type of spending on transit, including:

- Any mode of transit: commuter rail, light rail, bus rapid transit, paratransit, etc.

- Any nature of service: existing service, expansion of service, or planned new service

- Any type of spending: capital or operations and maintenance (O\&M)

Local governments, metropolitan planning organizations (MPO), and transit agencies in individual communities can use the results from this tool to answer questions that the key decision makers of their communities may have about spending on transit and its economic impacts on the local economy. The following are the types of questions that can be answered with the results from this tool:

- What does local transit service provide to the community economically?

- What are the economic impacts of improving this service?

- What are the economic impacts of removing this service?

- For every $\$ 1$ million of local, state, and federal funds spent for transit O\&M, how many jobs are supported?

- For every $\$ 1$ million of local, state, and federal funds spent for transit O\&M, how many jobs are created?

- For every $\$ 1$ million of local, state, and federal funds invested in transit capital projects, how many jobs are supported?

- For every $\$ 1$ million of local, state, and federal funds invested in transit capital projects, how many jobs are created?

- For every $\$ 1$ million of local funds spent on public transit, how many jobs are supported? 
- For every $\$ 1$ million of local funds spent on public transit, how many jobs are created?

To answer questions raised by decision makers in Central Florida, this tool was applied to the area's eight counties that currently have either urban or rural transit services. Some of these questions deal with the number of jobs supported or created by spending on transit for every dollar invested in providing transit services. The results differ significantly between spending for capital projects vs. spending for O\&M as well as across the counties. For example, the rate-of-return in terms of job creation is significantly greater for O\&M spending than for capital spending in these applications. Also, the leveraging effect of spending local resources is significantly greater for counties relying proportionally less on local resources. One critical reason for these differences is the pattern of funding sources and spending destinations-where the funds come from and where the funds are spent. The reader is cautioned that the relatively greater impact of O\&M spending over capital spending revealed from these applications may not extend to applications in other regions or even to applications in the future of Central Florida. For applications in the future of Central Florida, for example, patterns can change significantly if Central Florida gets designated tax revenues for its transit services.

Given the importance of funding sources and spending destinations, study areas need to be carefully defined when using this tool; they should be defined as areas that encompass where workers live and spend most of their earnings. It is not appropriate to apply this tool to an entire state, for example, when the transit service under consideration is provided only in a single region of the state. Applications to study areas that are too large lead to inflated estimates of impacts. At the same time, it is not appropriate to apply this tool to a study area that is too small relative to the area where workers live and spend most of their earnings. Applications to study areas that are too small not only require extra effort for attributing aggregated spending data but also lead to understating the true impacts.

The estimated impacts from using this tool represent the economic impacts that have resulted from not only the amount of annual spending but also the pattern of its funding source and the spending destinations. For a study area, the economic impacts of the same amount of spending could be significantly different if the pattern of its funding source and the spending destinations differ. Users of this tool should not try to estimate the economic impacts of future spending on transit from the economic impacts estimated for spending for a historical year. Instead, the tool should be applied separately to future spending on transit to re-estimate the likely economic impacts.

The tool is not designed to consider the transportation benefits of transit investments such as the improvement in someone's health as a result of their being able to reliably make medical appointments or the improvement in quality of life when someone is able to travel to socialize with the relative. Nor is it designed to estimate either the economic impacts of highway projects or the economic impacts of using funds for transit on highway projects. Rather, this tool is intended to provide an additional low-cost option for communities to get a fuller picture of the effects of spending their scarce resources for transit services in terms of the economic impacts on the local economy. 


\section{Appendix}

This appendix offers an alternative description of some of the design features of the tool in terms of the factors involved, their qualitative influence on estimated impacts, and the assumptions made. Most of these elements were covered in Chapter 2 about the various design features of the tool. This alternative description centers on a new table, Table A-1, that summarizes these factors and qualitative influences.

\section{Factors}

These factors relate to three issues in estimating the economic impacts of spending on transit: source of funds for the spending, characteristics of the spending, and approach to measurement.

Table A-1. Matrix of Methodological Factors and Their Qualitative Effects

\begin{tabular}{|c|c|c|c|c|c|c|c|c|c|}
\hline \multirow{5}{*}{$\begin{array}{l}\text { Measurement } \\
\text { Approach }\end{array}$} & \multicolumn{3}{|c|}{ Characteristics of Spending } & \multicolumn{6}{|c|}{ Source of Funds } \\
\hline & \multirow{4}{*}{ Destination } & \multirow{4}{*}{ Category } & \multirow{4}{*}{ Nature } & \multicolumn{5}{|c|}{$\begin{array}{l}\text { Outside Study Area } \\
\text { by Financing Method }\end{array}$} & \multirow{4}{*}{$\begin{array}{l}\text { Inside } \\
\text { Study } \\
\text { Area }\end{array}$} \\
\hline & & & & \multicolumn{3}{|c|}{$\begin{array}{l}\text { Non-Financed } \\
\text { (by degree of employment } \\
\text { in study area) }\end{array}$} & \multicolumn{2}{|c|}{$\begin{array}{l}\text { Financed } \\
\text { (by source of } \\
\text { payments) }\end{array}$} & \\
\hline & & & & \multicolumn{2}{|c|}{ Full Employment } & \multirow{2}{*}{$\begin{array}{l}\text { Partial } \\
\text { Employment } \\
\text { (C) }\end{array}$} & \multirow{2}{*}{$\begin{array}{l}\text { Outside } \\
\text { Study } \\
\text { Area } \\
\text { (D) }\end{array}$} & \multirow{2}{*}{$\begin{array}{l}\text { Inside } \\
\text { Study } \\
\text { Area } \\
\text { (E) }\end{array}$} & \\
\hline & & & & $\begin{array}{l}\text { Job } \\
\text { Impacts } \\
(A) \\
\end{array}$ & $\begin{array}{l}\text { Other } \\
\text { Impacts } \\
(B)\end{array}$ & & & & \\
\hline \multirow{4}{*}{ Net Impact } & \multirow{3}{*}{$\begin{array}{l}\text { Inside } \\
\text { study } \\
\text { area }\end{array}$} & Land cost & $(1)$ & 0 & 0 & 0 & 0 & 0 & 0 \\
\hline & & \begin{tabular}{|l|} 
Other \\
spending
\end{tabular} & 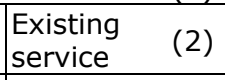 & + & + & + & + & 0 & 0 \\
\hline & & & \begin{tabular}{|l|} 
Service \\
expansion
\end{tabular} & 0 & + & + & + & 0 & 0 \\
\hline & \multicolumn{3}{|c|}{ Outside study area } & 0 & 0 & 0 & 0 & - & - \\
\hline \multirow{4}{*}{ Gross Impact } & \multirow{3}{*}{$\begin{array}{l}\text { Inside } \\
\text { study } \\
\text { area }\end{array}$} & Land cost & $(5)$ & 0 & 0 & 0 & 0 & 0 & 0 \\
\hline & & \multirow{2}{*}{$\begin{array}{l}\text { Other } \\
\text { spending }\end{array}$} & $\begin{array}{ll}\begin{array}{l}\text { Existing } \\
\text { service }\end{array} \quad(6) \\
\end{array}$ & + & + & + & + & + & + \\
\hline & & & $\begin{array}{l}\text { Service } \\
\text { expansion }\end{array}$ & + & + & + & + & + & + \\
\hline & \multicolumn{3}{|c|}{ Outside study area } & 0 & 0 & 0 & 0 & 0 & 0 \\
\hline
\end{tabular}

\section{Source of Funds}

The source of funds for the spending on transit in a given study area is either inside or outside the study area. When originated outside the study area, the funds could either be borrowed through bonds and loans or be from non-financed sources. The non-financed sources include revenues directly generated at the transit agency, general revenues of local, state, and federal governments, and tax revenues designated to transit. For financed spending, the debt repayments to be made in the future could come from outside or inside the study area. For non-financed spending, its potential impact on jobs also depends on the degree of employment in the study area. 
Full employment here refers the condition in the labor market in which there is no excess supply of or demand for labor at prevailing wages. The unemployment rate under this condition is referred to as the "natural rate of employment." The Congressional Budget Office (CBO) provides quarterly estimates of this natural rate for the U.S. as a whole. The estimated natural rate for historical years and the projected natural rate for future years have fluctuated from 4.8-6.0 percent; as a result, an unemployment rate of 4.8 percent or lower defines full employment for this tool.

\section{Characteristics of Spending}

The spending could be to purchase products and services that were produced either outside or inside the study area. When the spending is inside the study area, it is for either operations and maintenance (O\&M), the cost of land for capital projects, or other cost of capital projects. When the spending is for non-land costs, its potential impact on jobs can depend on the nature of transit service under consideration-existing service or service expansion in an area with existing service.

\section{Approach to Measurement}

The estimated impacts from the tool are either net or gross. Net impacts are truly created by the spending on transit considered and result from the positive effect of spending outside funds inside the study area and from the negative effect of spending inside funds outside the study area. These net impacts would not exist without the public transit service. These results also can reflect the economic impact of removing the transit service. Gross impacts are the estimated economic activities supported by all of the considered spending on transit made inside the study area without considering whether the funds originated from outside the study area. Gross impacts include the net impacts as well as the economic activities supported by the inside funds spent inside the study area. These results also can reflect the amount of economic activity that the transit service supports.

\section{Qualitative Influence}

When combined, these three issues and related factors lead to a matrix (Table A-1) that indicates how qualitatively they influence the estimated economic impacts of spending on transit. For ease of reference, the eight rows of the matrix are numbered by 1 through 8 and the six columns are labeled by $A$ through $F$. The qualitative influence of these factors is indicated by $0,+$, or - , described as follows:

- A " 0 " means that the impact of a spending on transit is assumed to be zero if this spending on transit is characterized by the corresponding two factors. For example, any spending using funds from inside the study area would have zero net impacts even if the funds are also spent inside the study area (i.e., cells F2, F3).

- A "+" means that the impact of a spending on transit could be positive if this spending on transit is characterized by the corresponding two factors. The same spending in the above example would have positive gross impacts (i.e., cells F6, F7). 
- A "-"means that the impact of a spending on transit could be negative if this spending on transit is characterized by the corresponding two factors. For example, any spending using funds from inside the study area would have negative net impacts if the funds are spent outside the study area (i.e., cell F4).

\section{Assumptions}

Many of the qualitative influences indicated in the matrix (Table A-1) represent the actual quantitative effects of the corresponding factors involved; no assumptions are used. The following are examples:

- Spending for existing transit services with funds from outside the study area generates positive net impacts if the funds are spent inside the study area.

- Spending with funds from outside the study area has zero net impact if the funds are spent outside the study area as well.

However, assumptions are made in determining the qualitative influences of many factors, particularly for those cells in the matrix with a "-" and a " 0 " in columns D, E, and $F$. The following are examples of some of these assumptions:

- Spending to pay for the cost of land for construction projects has no impacts. One assumption is that any transaction cost for land acquisition is either included in the construction cost or is negligible. Another assumption is that the spending would still be used to pay for the cost of land if transit service were not provided.

- Non-land spending inside the study area would have zero net impacts if borrowed funds were used and debt payments in the future would be made with funds from inside the study area (cells E2, E3). While the spending supports a certain amount of economic activities now, the debt payments will have a negative effect on the economy in the future. The underlying assumption is that the debt payments, including both interest and principle, would be roughly the same in present-day dollars as the borrowed funds.

- For cells E3, E4, F3, and F4, the assumption is that the expended funds from inside the study area would support the same level of economic activities as the actual spending on transit.

- For cells E4 and F4, the assumption is that if there were no transit service, the expended funds from inside the study area would have been left in the pockets of residents in the study area and be spent by them in the study area.

In most cases, these assumptions result in estimated impacts that are more conservative than without these assumptions. At the same time, however, the degree of understating the true impacts from making these assumptions is expected to be significantly lower than the degree of overstating the true impacts without making these assumptions. The motivation for making these assumptions is to reduce the amount of input data required from the user. 